\title{
RIZOBACTÉRIAS E SUAS INTERAÇÕES \\ COM PLANTAS E MICRORGANISMOS
}

\author{
SUELI DOS SANTOS FREITAS \\ Engenheira Agrônoma \\ Orientadora: Profa Dra ELKE JURANDY BRAN \\ NOGUEIRA CARDOSO
}

\begin{abstract}
Tese apresentada à Escola Superior de Agricultura "Luiz de Queiroz", da Universidade de São Paulo, para a obtenção do título de Doutor em Agronomia, Area de Concentração: Solos e Nutri çảo de Plantas.
\end{abstract}

\author{
PI RACI CABA \\ Estado de São Paulo - Brasil \\ Janeiro - 1994
}


Freitas, Sueli dos Santos

F884r Rizobactérias e suas interações com plantas e microrganismos.
Piracicaba, 1994.

$112 \mathrm{p}$.

Tese - ESALQ

Bibliografia.

1. Relação solo-planta-bactéria 2. Rizobactérias 3. Solo -: microbiologia I. Escola Superior de Agricultura Luiz de Queiroz, Piracicaba 


\section{RIZOBACTÉRIAS E SUAS INTERAÇÕES COM PLANTAS E MICRORGANISMOS}

SUELI DOS SANTOS FREITAS

Aprovada em: 11.4 .1994

Comissão julgadora:

Profa Dra Elke Jurandy Bran Nogueira Cardoso ESALQ/USP

Prof. Dr. Jorge de Castro Kiehl ESALQ/USP Profa Dra Siu Mui Tsai CENA/USP Dr. Jaciro Soave I AC Dra Raquel Ghini CNPMA/EMBRAPA

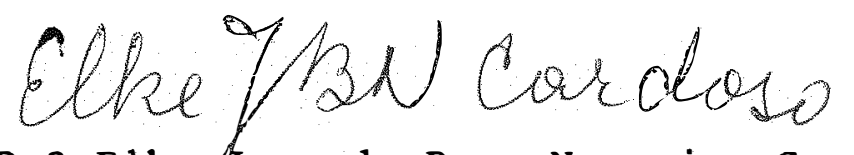

Profa Dra Elke Jurandy Bran Nogueira Cardoso Orientadora 
A minha mãe e minha família, pelo estímulo e carinho, ofereço.

$$
\begin{gathered}
\text { A Jorge, doutor em } \\
\text { carinho e muita paciência, } \\
\text { dedico. }
\end{gathered}
$$




\section{AGRADECIMENTOS}

A Dra Elke Jurandy Bran Nogueira Cardoso. Aos colegas Drs. Manoel Albino Coelho de Miranda, Adriana Parada Dias da Silveira, Maria Angélica Pizzinatto, Hiroshi Nagai, Violeta Nagai, Lúcia Regina Cangussu da Silva, Maria Aparecida de Souza Tanaka, Margarida Fumiko Ito e Maria Luiza Colognesi de Oliveira Lombardi, do Instituto Agronômico.

Aos funcionários do Instituto Agronômico Rosana Gierts Gonçalves, Valéria Cristina Vieira, Eduardo Bezerra Silva, Maria Leonilde Machado de Souza e Silvana Cristina Teixeira.

Ao Instituto Agronômico, particularmente às Seções de Microbiologia do Solo, Leguminosas e Conservação do Solo.

A Escola Superior de Agricultura "Luiz de Queiroz".

A IBRAS-CBO, de Campinas.

Ao Conselho Nacional de Desenvolvimento Científico e Tecnológico - CNPq.

A todos que colaboraram para a realização deste trabalho: mencionar cada favor prestado seria uma longa lista e agradecer-lhes à altura, impossível. 
SUMARIO

Página

RESUMO

vi i

SUMMARY

1. INTRODUÇÃO .

2. REVISÃO DE LITERATURA . . . . . . . . . . . . . . . 4

2.1. Produção de substâncias promotoras de crescimento . . . . . . . . . . . . . . . . . . . 9

2.2. Produção de sideróforos ......... 15

2.2.1. Generalidades . . . . . . . . 15

2.2.2. Sideróforos e nutrição de plantas . . 20

2.2.3. Sideróforos e controlebiologico... . 26

2.2.4. Sideróforos: outros aspectos ......30

2.3. Produção de antibióticos . . . . . . . . . 33

2.4. Rizobactérias deletérias . . . . . . . . . . . 36

2.5. Interações de micorrizas e microbiota rizosférica. . . . . . . . . . . . . . 37

2.6. Inconsistência no uso de RPCPs . . . . . . . 39

3. MATERIAL E MEtODOS . . . . . . . . . . . . . . 41 
3.1. Obtenção dos isolados . . . . . . . . . 4 41

3.2. Solo...................... 44 44

3.3. Experimento com feijão.......... . . 44

3.4. Experimento com milho......... 46

3.5. Experimento com tomateiro........ . 48

3.6. Experimentos com soja............... 49

3.6.1. Cultivar Santa Rosa . . . . . . 49

3.6.2. Cultivar Santa Rosa Clorose . . . . . 49

3.6.3. Cultivar T-203 .......... . 51

3.7. Testes de antagonismo . . . . . . . . . . 52

4. RESUltados E DisCUSSÃO . . . . . . . . . . . . 54

4.1. Experimento com feijão . . . . . . . . . 54

4.2. Experimento com milho.......... . 62

4.3. Experimento com tomateiro........ 68

4.4. Experimentos com soja . . . . . . . . . 73

4.5. Testes de antagonismo... . . . . . . . . 82

5. CONCLUSÕES . . . . . . . . . . . . . . . . . . . . 88

REFERENCIAS BIBLIOGRAFICAS . . . . . . . . . . 89 


\section{RIZOBACTÉRIAS E SUAS INTERAÇÕES \\ COM PLANTAS E MICRORGANISMOS}

Autora: SUELI DOS SANTOS FREITAS

Orientadora: PROFa DR $\underline{a}$ ELKE JURANDY BRAN NOGUEIRA CARDOSO

RESUMO

O objetivo deste estudo foi obter isolados de rizobactérias promotoras do crescimento de plantas (RPCPs) e identificar, exploratoriamente, alguns de seus possíveis modos de ação, em experimentos em casa de vegetação, com amostras de um latossolo vermelho-amarelo, com valor de pH em $\mathrm{CaCl}_{2}$ de 6,3 , utilizando diversos sistemas planta-microrganismos.

Conduziu-se um experimento com feijão (Phaseolus vulgatis), com inoculação dos fungos micorrizicos Glomus etunicatum (GE) e scutellospora heterogama ( $\mathrm{SH}$ ), de dezesseis isolados fluorescentes de Pseudomonas spp. e de Rhizobium leguminosarumbv. phaseoli. Dois isolados de Pseudomonas foram patogênicos às plantas, mas vários deles resultaram em aumento de quase todas as variáveis analisadas (matéria seca de raízes e nódulos, 


\section{vi i i}

nitrogênio e fósforo na parte aérea e infecção radicular pelos fungos micorrízicos). Houve interações das bactérias fluorescentes com os fungos micorrízicos, quase sempre com melhor resultado para a inoculação conjunta com GE.

Conduziu-se um experimento com milho (Zea mays) em solo natural e esterilizado e inoculação de 46 isolados de Pseudomonas spp. Em quatorze tratamentos de inoculação houve morte das plantas no solo natural mas não no esterilizado e em outro tratamento as plantas morreram no solo esterilizado mas não no natural. Não houve efeito benéfico de isolados bacterianos sobre a matéria seca de parte aérea ou de raízes.

Conduziu-se um experimento com tomateiro (Lycopersicon esculentum) em solo natural e esterilizado e 46 tratamentos de inoculação com Pseudomonas spp. fluorescentes e dezesseis de Bacillus spp. Um isolado de Pseudomonas e um de Bacillus tiveram efeito negativo sobre a matéria seca da parte aérea das plantas cultivadas em solo esterilizado. Não houve efeito benéfico de isolados bacterianos sobre a matéria seca de parte aérea e de raízes.

Conduziram-se três experimentos com soja (Glycine $\max$ ). Num deles, com a cultivar Santa Rosa, as plantas foram cultivadas em solo natural e esterilizado e inoculadas com 46 isolados fluorescentes de Pseudomonas spp. Não houve efeito dos isolados sobre a matéria seca de parte aérea e de raízes. Nos outros experimentos, com as 
cultivares Santa Rosa Clorose e T-203, inocularam-se 28 isolados fluorescentes de Pseudomonas spp. apenas em solo natural. Ocorreu deficiência de ferro nas plantas, avaliadas visualmente por notas de 1 (planta sem sintomas de deficiência) a 5 (planta clorótica com manchas necróticas). Não houve efeito estatisticamente significativo das bactérias sobre a deficiência de ferro, avaliada por notas, ou sobre a massa seca da parte aérea no experimento com a cultivar Santa Rosa Clorose. No experimento com a T-203, a inoculação com um dos isolados resultou em notas menores em relação à testemunha nãoinoculada e com outro isolado, em maior massa de parte aérea.

Confrontaram-se "in vitro" os 46 isolados de Pseudomonas spp. e dezesseis de Bacillus spp. com 24 fungos de solo, fitopatogênicos ou não. As bactérias fluorescentes apresentaram variadas reações de antagonismo aos fungos enquanto que os Bacilli tivefam comportamento mais uniforme.

De maneira geral, concluiu-se que o efeito benéfico de rizobactérias pode resultar da interação com micorrizas. O antagonismo a fitopatógenos foi observado "in vitro". Em soja, algumas evidências sugeriram que RPCPs podem fornecer ferro a plantas crescendo em condições de baixa disponibilidade do nutriente, mas há necessidade de estudos comprobatórios. Rizobactérias também podem ser deletérias às plantas. 


\title{
RHIZOBACTERIA AND THEIR INTERACTIONS WITH PLANTS AND MICROORGANISMS
}

\author{
Author: SUELI DOS SANTOS FREITAS \\ Adviser: PROF $\underline{a}$ DR $\underline{a}$ ELKE JURANDY BRAN NOGUEIRA CARDOSO
}

SUMMARY

The objective of this study was to obtain plant growth-promoting rhizobacteria (PGPR) isolates and to identify, tentatively, some of their possible modes of action, in greenhouse trials on a red-yellow latosol with a pH 6.3 in $\mathrm{CaCl}_{2}$, using some plant-microorganisms systems. An experiment was carried out with common beans (Phaseolus vulgaris) inoculated with mycorrhizal fungi Glomus etunicatum (GE) and scutellospora heterogama (SH), sixteen fluorescent pseudomonad isolates and Rhizobium leguminosarum bv. phaseoli. Two fluorescent isolates were pathogenic, but some of them increased almost all variables analysed (shoot and nodules dry weight, shoot content of nitrogen and phosphorus and mycorrhizal root infection).

There were interactions of fluorescent 
bacteria with mycorrhizal fungi and frequently the best results were for the dual inoculation with GE.

An experiment was carried out with maize l zea mays) on natural and sterilized soil and with inoculation of 46 pseudomonads. In fourteen inoculation treatments there was plant death in natural soil but not in sterilized one. In another treatment the plants died in sterilized soil but not in natural one. There were no beneficial effects of bacterial isolates on shoot and root dry we ights.

An experiment was carried out with tomato plants (Lycopersicon esculentum) in natural and sterilized soil and with inoculation of 46 pseudomonads and sixteen Bacillus spp. isolates. One Pseudomonas and one Bacillus isolate had negative effect on shoot dry weight of plants grown in sterilized soil. There were no beneficial effects of bacterial isolates on shoot and root dry weights.

Three experiments were carried out with soybean (Glycine $\max$ ). In the experiment with Santa Rosa cultivar the plants were grown in natural and sterilized soil and inoculated with 46 fluorescent pseudomonads. There were no inoculation effects on shoot and root dry weights. In the other experiments, with Santa Rosa Clorose and T-203 cultivars the plants were inoculated with 28 fluorescent pseudomonads and grown only in natural soil. The plants presented iron deficiency, which was evaluated by visual scores from 1 (plant with no deficiency symptom) to 5 
(chlorotic plant with necrosis). In the experiment with Santa Rosa Clorose there was no statistically significant effect of bacterial isolates. In the experiment with T-203 the inoculation with one isolate resulted in lower scores than the non inoculated plants. Another isolate had a positive effect on shoot dry weight.

Forty-six pseudomonads and sixteen of Bacilli were tested against 24 soil fungi "in vitro". The fluorescent bacteria presented several antagonistic reactions to the fungi but Bacilli had more uniform reactions.

It was concluded that rhizobacteria may interact positively with mycorrhizae. The antagonism against plant pathogens was only observed "in vitro". In soybean some evidences have suggested that PGPR may supply iron to plants growing at low availability conditions of this nutrient, but corroborating studies are needed. Rhizobacteria may be also deleterious to the plants. 
1. I NTRODUÇĀO

O efeito que os microrganismos exercem sobre o crescimento das plantas ainda está muito longe de ser entendido. Conhece-se maior número de microrganismos patogênicos que de microrganismos benéficos, provavelmente porque os patógenos, pelo menos os mais conhecidos, estabelecem relações mais íntimas com as plantas. Entre os microrganismos benéficos, são mais estudados justamente os que estabelecem. relações simbióticas com as plantas, como, por exemplo, as bactérias dos gêneros Rhizobium e Bradyrhizobium e os fungos micorrízicos.

Para todos esses organismos, seus efeitos e/ou sintomas são mais facilmente detectáveis, o que, seguramente, contribui para o maior interesse que despertam. Todavia, há outras formas, menos óbvias, de microrganismos causarem benefícios ou malefícios às plantas. Há inúmeros modos de microrganismos exercerem efeitos benéficos que não são facilmente percebidos. Entre esses modos estão a mineralização de nutrientes, a solubilização de fosfatos e a própria alteração da morfologia radicular (CARDOSO \& FREITAS, 1988). Entre os patógenos, estão incluídos os chamados "patógenos menores" 
ou "sub-clínicos", que se estabelecem na região das raízes e causam depressão geral no crescimento das plantas, que não apresentam sintomas claros de doença; essa depressão no crescimento nem sempre é percebida. Assim ocorre com outras atividades microbianas.

As rizobactérias promotoras do crescimento de plantas (RPCPs), por exemplo, são organismos cujo estudo vem merecendo destaque nos últimos anos, particularmente as espécies do gênero Pseudomonas, possivelmente porque se estabeleçam melhor na rizosfera do que outros gêneros de bactérias (ROUATT \& KATZNELSON, 1961), o que lhes confere certa vantagem. Fora do Brasil muitos trabalhos vêm sendo conduzidos e publicados sobre RPCPs, havendo relatos de benefícios nas mais variadas culturas como batata, beterraba, nabo, trigo e outras. Todavia, em cada caso o isolado de RPCP parece agir de um modo, seja pela produção de substâncias promotoras de crescimento, seja por controle biológico de fitopatógenos, ou seja, ainda, por interferência na nutrição da planta. Há trabalhos evidenciando todos esses modos de ação, às vezes ma is de um mecanismo para o mesmo isolado de bactéria. Em nem todos os casos o modo de atuação das RPCPs está bem definido, mas já existem, no exterior, inoculantes com essas bactérias (PAAU \& MCINTYRE, 1987). A inoculação de RPCPs, por inoculantes sólidos ou pela água de irrigação, propicia, de alguma forma, melhoria no crescimento de muitas espécies veget a is. 
É o conhecimento do mecanismo de ação das RPCPs que definirá, em última análise, a melhor utilização dos isolados benéficos, em cada interação planta-bactéria. Dado que o modo de ação e a própria ocorrência do benefício variam com a espécie de planta e/ou bactéria, é vital conhecer-se o mecanismo dessas interações nas condições brasileiras. Aqui tornam-se particularmente importantes o conhecimento de processos e a aplicação de técnicas que resultem em utilização mais eficiente de insumos. No mundo todo, os rumos tomados pela agricultura exigem a investigação de fenômenos que resultem no emprego de técnicas não-agressivas ao ambiente.

Assim, o objetivo deste trabalho é obter isolados de bactérias benéficos a plantas e identificar seu modo de ação. Para isso, serão usados diferentes modelos de interações plantas-microrganismos que indiquem, ainda que de maneira exploratória, os modos de ação pelos quais se exercem os beneficios. Os isolados bacterianos a serem testados serão obtidos de diferentes espécies vegetais. 
Há mais de trinta anos tinha boa divulgação nos meios cientificos ocidentais o uso que a união Soviética fazia dos chamados "fertilizantes bacterianos". Um pesquisador inglês, da Estação Experimental de Rothamsted, passou seis meses visitando um grande número de laboratórios e estações experimentais em Moscou, Leningrado, Kiev, Tashkent e Alma-Ata, e seu relatório sobre essa viagem foi depois publicado na revista "Soils and Fertilizers" (COOPER, 1959). O autor relata que dez milhões de hectares, na época de sua visita, recebiam fertilizantes bacterianos. Um deles, o "azotobacterin", constituído por bactérias do gênero Azotobacter, tinha efeitos benéficos em 50 a $70 \%$ das lavouras em que era aplicado, com $10 \%$ de aumento médio de produção. Além desse, também eram usados outros inoculantes: "phosphobacterin", feito com Bacillus megatherium var. phosphaticum, e "nitragin", de Rhizobium spp., principalmente, a lém dos produzidos com espécies do gênero Pseudomonas, particularmente P. fluorescens. BROWN (1974) cita vários autores russos que teriam obtido aumentos na produção da ordem de 5 a $8 \%$ em milho, 24 a $42 \%$ em arroz, 
$10 \%$ em soja, 18 a $25 \%$ em batata, entre outras culturas, apenas com o uso de fertilizantes bacterianos.

O interesse dos pesquisadores ocidentais. entretanto, era limitado pelo fato de que os primeiros trabalhos sobre esse assunto nem sempre tinham análises estatísticas (BURR \& CAESAR, 1985) e apresentavam grande variabilidade, já mencionada por COOPER (1959) para o "azotobacterin", cujos insucessos eram atribuídos à falta de umidade.

Quinze anos atrás, no trabalho de KLOEPPER \& SCHROTH (1978) cunhava-se a expressão "rizobactérias promotoras do crescimento de plantas (RPCPs)", que designa bactérias que vivem na rizosfera e são benéficas às plantas, sem estabelecerem com as mesmas relações simbióticas. No mesmo ano, BURR et al. (1978) apresentaram dados de aumentos significativos na produção de batatas pela inoculação de Pseudomonas fluorescens e P. putida.

A partir daí, intensificaram-se os trabalhos com as agora chamadas RPCPs. Diferentemente dos trabalhos iniciais, passaram a ser estudadas as bactérias do gênero Pseudomonas, que se estabelecem na rizosfera melhor que Azotobacter spp. e Bacillus spp., uma das possíveis razões de insucesso nos experimentos anteriores (BURR \& CAESAR, $1985)$

Hoje há relatos de benefícios em maçã (CAESAR \& BURR, 1987), trevo subteriâneo (MEYER \& LINDERMAN, 1986a), alfafa (OLSEN \& MISAGHI, 1981), beterraba (SUSLOW 
\& SCHROTH, 1982), café (FREITAS, 1989), milho (BRANDãO, 1989) e várias plantas ornamentais floríferas (YUEN \& SCHROTH, 1986), entre outras.

O grupo fluorescente de Pseudomonas spp. foi muito bem definido por STANIER et al. (1966), num trabalho clássico sobre a taxonomia do gênero Pseudomonas: pertencem ao grupo fluorescente as espécies que produzem pigmento fluorescente no meio B de KING et al. (1954) observado sob luz com comprimento de onda próximo do ultravioleta. Essas espécies são: $P$. aeruginosa, $P$. fluorecens e $P$. putida. As duas últimas espécies pertencem, muito freqüentemente, as RPCPS .

Há muito já se sabe que bactérias do gênero Pseudomonas têm seu desenvolvimento favorecido na rizosfera (CHAN \& KATZNELSON, 1961 e ROUATT \& KATZNELSON, 1961). Rizosfera, conforme definido por HILTNER (1904), é a região do solo sob influência das raízes. As raízes exercem sua influência pela exsudação, para o solo, de um grande número de substâncias orgânicas: açúcares, compostos aminados, ácidos orgânicos, fatores de. crescimento, etc. (CURL \& TRUELOVE, 1985). Uma vez que a maioria dos microrganismos depende de matéria orgânica para sua alimentação, os exsudatos radiculares tornam a rizosfera uma região densamente povoada por microrganismos quando comparada ao solo não-rizosférico: ROUATT et al. (1960) observaram que a comunidade bacteriana em solo rizosférico era 23 vezes maior que em solo não-rizosférico. Essa influência da 
exsudação é, considerando-se os muitos fatores que a podem afetar, de alguns milímetros em torno das raízes (CARDoso \& FREITAS, 1992) mas é essa a região que microrganismos devem atravessar para ter contato com a planta, sejam eles benéficos ou patogênicos. O sucesso do microrganismo na rizosfera é passo importante para o estabelecimento de qualquer relação com a planta.

SCHER \& SCHROTH (1987) consideraram a colonização das raízes por uma RPCP um ponto crítico para que ocorra realmente a promoção de crescimento, mencionando mesmo que se deveria tentar obter dados sobre a colonização de segmentos específicos de raiz em vez do sistema radicular como um todo. Há isolados de RPCPs que colonizam as raízes e/ou a rizosfera agressivamente, conforme ALBERT \& ANDERSON (1987) observaram para $P$. putida. A pergunta naturalmente decorrente dessa observação é: estará essa capacidade de colonização associada a alguma alteração das propriedades da raiz pela bactéria?

Sabe-se que há perdas de aglutininas das raízes para o solo (ANDERSON, 1983). Tais substâncias têm alto peso molecular e são complexos de proteínas e carboidratos, que poderiam facilitar, por exemplo, a fixação das células bacterianas no rizoplano, a interface solo-raiz (ANDERSON, 1983). A composição e a quantidade dos exsudatos radiculares são determinadas geneticamente, permitindo que se suponha uma certa especificidade na relação planta-bactéria: a rizosfera de uma determinada 
espécie de planta favoreceria o desenvolvimento de espécie bacteriana mais bem adaptada àquela justa composição de exsudatos radiculares. Partindo desse princípio, GLANDORF et al. (1993) isolaram Pseudomonas spp. de rizosfera de batata, trigo e uma gramínea forrageira, obtendo cerca de cinqüenta isolados por cultura. Compararam os padrões de lipopolissacarídeos (LPS) e proteínas do envelope celular (PEC) desses isolados, obtendo aproximadamente trinta padrões diferentes para cada cultura. A maioria desses padrōes de uma cultura não se repetia nas outras, sugerindo uma especificidade dos isolados obtidos em cada espécie vegetal. Todavia, quando cada espécie de planta foi inoculada com o conjunto de isolados, os autores não observaram especificidade na colonização de suas raízes.

Dois pontos que merecem menção em quase todos os trabalhos com RPCPs são o desconhecimento sobre o seu modo de ação e a importância de descobri-lo. É claro que, dado o pouco conhecimento sobre as RPCPs, em geral, muitos aspectos de sua atividade necessitam de esclarecimento. Embora a esmagadora maioria dos trabalhos seja com Pseudomonas spp. também há estudos com bactérias dos gêneros Azospirillum (BASHAN et al., 1989 e ZAADY et al., 1993), Azotobacter (HOWELL \& OKON, 1987), Bacillus e Serratia (LALANDE et al., 1989). Cada gênero ou espécie deve agir por modos diferentes, ou mesmo cada isolado de uma única espécie. Indo um pouco mais além, um mesmo isolado pode interagir de maneiras diferentes com culturas 
vegetais diversas. Não obstante, é fundamental detectar-se a forma pela qual se exerce o benefício em cada interação planta-bactéria. Além de esse conhecimento, em alguns casos, permitir o manejo das condições de cultivo, de modo a maximizar o benefício, em outros casos permitirá que se identifiquem razões de insucesso muito comuns na aplicação de RPCPs.

A seguir serão discutidos os principais modos de ação sugeridos para RPCPs.

2.1. Produção de substâncias promotoras de crescimento

Na década de 60 , parte significativa dos trabalhos com RPCPs concentrou-se na hipótese de que o efeito benéfico dessas bactérias era pela produção de substâncias promotoras de crescimento. O grupo da Dra. Margaret E. Brown publicou vários trabalhos nessa linha de pesquisa (BROWN et a l., 1962, 1964, 1968 e BROWN, 1972). Enquanto na União Soviética, na década anterior, presumiase que o efeito do fertilizante bacteriano "Azotobacterin" era sobre a nutrição nitrogenada da planta, trabalhava-se agora com o fato de que Azotobacter sp. produzia hormônios que afetariam o crescimento vegetal. Aliás, ainda hoje, a grande maioria dos trabalhos com RPCPs na área de produção de fitormônios é com as bactérias dos gêneros Azotobacter e Azospirillum, que têm com as plantas relações nãosimbióticas. Assim, já se observou, por exemplo, que o 
crescimento de Azotobacter chroococcum é estimulado em presença de exsudatos de raízes de milho: a produção de auxinas, citocininas e giberelinas pela bactéria também é aumentada pela adição daqueles exsudatos ao meio dé cultura (MARTINEZ-TOLEDO et a 1., 1988).

BASHAN et al. (1989) inocularam plântulas de tomate com um mutante de Azospirillum não-fixador de nitrogênio. Como observaram promoção do crescimento, detectada pelo aumento da massa das folhas e da circunferência do caule, concluíram que o efeito benéfico não é pela fixação biológica de nitrogênio. GAMO (1991) não usou o recurso de um mutante não-fixador e concluiu que suas bactérias, isoladas como fixadoras de $\mathrm{N}_{2}$ a partir de raízes de algumas gramíneas e não-gramíneas, promoveram o crescimento das plantas por fixação de nitrogênio e por estimular o desenvolvimento das raízes pela produção de hormônios .

O efeito dos hormônios produzidos por $A$. brasilense, ácidos indol-acético e indol-lático, giberelina e cinetina é semelhante, sobre as plantas, ao obtido com hormônios puros: há aumento, por exemplo, no número de raízes laterais, que ficam mais densamente cobertas com pêlos radiculares (TIEN at al., 1979). Nesse caso, o efeito seria direto, o hormônio provocando elongação dos tecidos radiculares, mas há outras conseqüências: o aumento no número de raízes deve aumentar a absorção de nutrientes, levando a maior desenvolvimento de toda a planta. Esse foi 
um dos modos de ação propostos por FREITAS \& GERMIDA (1992) para a promoção de crescimento de plantas de trigo como resultado da inoculação com Pseudomonas fluorescentes.

Há poucos trabalhos considerando a produção de hormônios por Pseudomonas fluorescentes, mas o conhecimento de que podem fazê-lo não é recente: EKLUND (1970) inoculou sementes de abóbora com tais bactérias e observou aumento da emergência de plântulas, maior e longação do hipocótilo e maior área foliar, ainda que não tenha havido aumento na produção; alguns dos isolados usados eram produtores de giberelinas, fato que o autor considerou na explicação dos efeitos observados. Os trabalhos de LIFSHITZ \& RENNIE (1987), com P. putida em "canola" (Brassica campestris), e FREITAS (1989), com Pseudomonas spp. em café, conduzidos em condições axênicas, podem levar a hipóteses semelhantes.

Lembrando-se ainda dos efeitos indiretos do maior desenvolvimento radicular proprocionado por RPCPs e/ou hormônios, convém citar AZCON \& BAREA (1978): esses autores observaram que a inoculação conjunta de bactérias e fungos micorrizicos do gênero Glomus deu melhores resultados que a inoculação apenas com Glomus, mas não tinham elementos para julgar os motivos dessa interação. Houve maior infeção das raízes pelo fungo quando a inoculação era conjunta. A aplicação de sobrenadantes livres de células teve o mesmo efeito sobre as plantas que hormônios aplicados puros, em concentrações semelhantes. 
Efeito sobre a nutrição também foi obtido com a inoculação de uma RPCP, Bacillus firmus, previamente testada como solubilizadora de fosfato, a partir de fosfato de cálcio insolúvel, e produtora de AIA, por DATTA et al. (1982). Os autores concluíram que o aumento na produção de arroz obtido pela inoculação da bactéria em presença de fosfato insolúvel pode ser creditado tanto à capacidade da bactéria de solubilizar fosfato quanto de aumentar o sistema radicular, pela produção de hormônios, melhorando a extração de nutrientes do solo. Cumpre notar que, num fato raro, DATTA et al. (1982) recomendam a inoculação da bactéria no campo, com suplementação de matéria orgânica, quando necessário, como fonte de alimento para o microrganismo, e de fosfato de rocha, na dose de $17,5 \mathrm{~kg}$ de $P$ por hectare. Os pesquisadores consideraram que a bactéria não deveria ter problemas de estabelecimento no solo porque produz endósporos, estruturas altamente resistentes a quaisquer condições adversas.

A inoculação com RPCPs produtoras de fitormônios pode ser vantajosa também em plantas cujo órgão de consumo é a parte aérea: OLSEN \& MISAGHI (1981) citam aumentos extraordinários de $194 \%$ e $167 \%$ da massa de alfafa inoculada com células vivas e mortas, respectivamente, de P. fluorescens. Esses resultados mostram que a resposta de crescimento da planta não depende da atividade metabólica da bactéria na rizosfera.

FRANKENBERGER J I \& POTH (1988), trabalhando 
com culturas livres de células de uma rizobactéria isolada de gramínea (Festuca octoflora), obtiveram uma transaminase que catalisa a conversão de L-triptofano a ácido indolpirúvico, precursor do AIA. Apesar de não terem identificado a bactéria, que era Gram negativa, à semelhança do gênero Pseudomonas, os autorés lembram que $P$. fluorescens produz essa transaminase. Esse aspecto, aliás, é outra forma de abordagem da área de pesquisa de RPCPs e produção de hormônios: a bactéria, de alguma forma, afetaria a produção de hormônios pela planta. Numa tentativa de elucidar esse ponto, ALBERT \& ANDERSON (1987) mediram as atividades de peroxidase e oxidase do AIA em extratos de meios em que se cultivara $P$. putida e em plantas inoculadas com a bactéria. Peroxidades catalisam funções como a geração de material mais firme da matriz protéica da parede celular, polimerização de radicais fenóxi para produzir lignina e suberina, fortalecendo a parede celular, etc. Já a oxidação do AIA leva à sua inativação e faz parte do controle do sistema de hormônios que regulam o crescimento vegetal. Nesse trabalho não se detectou atividade de peroxidase ou de oxidase do AIA em células ou extratos de P. putida; todavịa, essa atividade foi maior nas plantas inoculadas com a bactéria que nas não-inoculadas. Detectaram-se, inclusive, outras formas de peroxidase nas plantas inoculadas. Tais peroxidades foram originárias da planta, possivelmente nas células epidérmicas da raiz. A partir desses dados, pode-se até 
levantar a hipótese da participação de RPCPs num sistema de regulação hormonal que pressuporia ụma associação mais íntima entre planta e bactéria, que até agora não se conseguiu provar.

O envolvimento de RPCPs nesse sistema pode se dar por várias maneiras e em vários níveis. ARSHAD \& FRANKENBERGER Jr. (1991), apresentando uma série de experimentos nessa linha de pesquisa, mencionam que Pisolithus tinctorius, um fungo ectomicorrizico, estimulou o crescimento de uma conífera somente quando recebeu t ambém L-triptofano, um precursor do AIA. Também observaram que isolados de Azotobacter spp. e Pseudomonas spp. produziram citocininas. Consideram que a inoculação é mais eficiente em afetar beneficamente o crescimento de plantas quando é feita em presença de um precursor da síntese hormonal em vez de se inocular só a bactéria. Igualmente, é melhor aplicar um precursor juntamente com uma bactéria selecionada previamente que só o precursor, indicando a superioridade do microrganismo inoculado sobre a microbiota nativa. Os autores concluem recomendando que a microbiota rizosférica seja intensivamente pesquisada em sua habilidade de sintetizar fitormônios a partir de um dado substrato.

De maneira geral, pode-se afirmar que poucos grupos de pesquisadores vêm trabalhando com a hipótese de que a promoção de crescimento de plantas por Pseudomonas seja por produção de hormônios. 
2.2. Produção de sideróforos

2.2.1. Generalidades

Embora o ferro seja um elemento abundante no solo, sua deficiência pode ocorrer em solos calcários. A sua solubilidade é controlada pelo equilíbrio químico dado pela equação (MENGEL \& KIRKBY, 1987):

$$
\mathrm{Fe}^{3+}+3 \mathrm{OH}^{-} \mathrm{Fe}(\mathrm{OH})_{3} \quad(\mathrm{~s} \delta \text { lido) }
$$

$\mathrm{O} F(\mathrm{OH})_{3}$ precipita-se e a atividade do $\mathrm{Fe}^{3+}$ diminui com o aumento de pH. Com valores de pH na neutralidade, a concentração do íon férrico solúvel é de cerca de $10^{-17} \mathrm{M}$, o que é muito pouco até para o crescimento microbiano (LEONG, 1986). Para obter e transportar ferro, organismos vivos freqüentemente o complexam com quelatos orgânicos que se combinam com o ferro inorgânico e aumentam grandemente a sua solubilidade (REID et al., 1986). Segundo REID et al. (1986), para que o elemento seja obsorvido pelas plantas, as concentrações de ferro solúvel devem ser da ordem de $10^{-8} \mathrm{M}$; em meio neutro ou alcalino, só $\mathrm{Fe}^{2+}$ e suas espécies de hidrólise podem atingir essa concentração. E conhecido o uso de quelatos para fornecer ferro a plantas em cultivos hidropônicos.

Para resolver seus problemas de obtenção de ferro, alguns microrganismos e plantas produzem sideróforos (do grego "sideros", ferro, e "phorós", que leva, que conduz), que são agentes quelantes do íon férrico, de baixo 
peso molecular (RAYMOND et al., 19S4). Foram descobertos em 1911, por Twort e Ingram (RAYMOND et al., 1984) como substancias essenciais para o crescimento de certas bactérias, sem que, no entanto, se soubesse a razão de sua essencialidade. Foi só meio século depois que BURNHAM \& NEILANDS (1961) apresentaram evidências de que os então chamados ferricromos (ou siderocromos ou sideraminas) tinham função de agentes transportadores de ferro no metabolismo microbiano, mostrando que o conteúdo de ferro de células de Arthrobacter sp., isolado JG-9, dependia da quantidade de ferricromo produzido. O ferro é muito importante em quase todos os processos de oxidação e redução nas células, mas o hidróxido férrico é insolúvel no pH fisiológico; assim, só poderosos agentes quelantes, como os sideróforos, podem mobilizar o ferro do ambiente. e facilitar seu transporte para a célula microbiana (RAYMOND et a 1., 1984).

Sideróforos são caracterizados pelas seguintes propriedades (MEYER \& HORNSPERGER, 1978):

1a) Sua sintese é induzida somente quando as células microbianas estão deficientes em ferro.

2a ) Complexam especificamente $\mathrm{Fe}^{3+}$ e têm fraca ou nenhuma afinidade por $\mathrm{Fe}^{2+}$.

3a ) Os complexos de Fe(III) têm constantes de estabilidade muito altas (da ordem de $10^{32}$ ).

4a) Como resultado de sua habilidade de complexar $\mathrm{Fe}^{3+}$, os siderofóros aumentam a taxa de entrada desse cátion na 
célula.

Por sua habilidade em complexar ferro, tais compostos são usados na medicina humana para remover ferro do corpo após envenenamento agudo por esse elemento e no tratamento da $\beta$-talassemia (RAYMOND et a 1. , 1984), uma vez que a quantidade total de ferro em tecidos vivos é baixa. Ao contrário de certas substâncias orgânicas, que podem ser acumuladas na forma de polímeros inócuos, íons metálicos geralmente não são armazenados em grandes quantidades por tecidos vivos, devendo sua quantidade ser regulada por absorção controlada (BAGG \& NEI LANDS , 1987).

De maneira geral, sideróforos fúngicos apresentam grupos hidroxamato para ligação do Fe(III) enquanto as bactérias têm também grupos catecolato (LEONG, 1986). Até pelo seu número _ mais de oitenta isolados e caracterizados nas últimas três décadas _ sabese que sideroforos variam muito, estruturalmente, mas seu aspecto comum é formar complexos octaédricos com o íon férrico, de grande estabilidade termodinâmica (RAYMOND et a 1., 1984$)$.

As moléculas de sideróforos féricos são muito grandes para passar pelos pequenos poros da membrana celular; assim, há necessidade de remoção do ferro do complexo para que possa penetrar a célula: a liberação do ferro do complexo Fe-sideróforo dá-se provavelmente por redução, já que sideróforos têm pouca afinidade por 
Fe(II) (LEONG, 1986). Essa redução, pelo menos em microrganismos, é feita, provavelmente, por via enzimática (RAYMOND et al., 1984). A absorção do ferro de sideróforos, em microrganismos, é processo ativo, dependente de energia e de receptores, que são proteínas externas à membrana cuja síntese é induzida por estresse de ferro (LEONG, 1986). Em geral, os sintomas de transporte de ferro por meio de sideróforos são específicos: em resposta à deficiência do elemento são sintetizadas proteínas localizadas em diferentes compartimentos celulares para transportar o elemento para o interior das células (HOHNADEL \& MEYER, 1988).

Segundo BOSSIER \& VERSTRAETE (1986), o fator dominante a determinar a produção de sideróforos no solo parece ser a disponibilidade de substrato orgânico para o crescimento microbiano: a composição dos exsudatos radiculares, a lém da sua própria presença, pode ser um fator importante a controlar a produção de sideróforos no solo. Chega-se, pois, à conclusão de que a rizosfera é provavelmente o local mais importante de produção de sideróforos no solo, justamente pela presença de exsudatos radiculares. Nesse caso, a disponibilidade de ferro na rizosfera pode ser diminuída pela absorção pelas plantas e pelos microrganismos; então, microrganismos produtores de sideróforos utilizariam com vantagem os exsudatos radiculares para a produção de mais sideróforos. Aventa-se mesmo a hipótese de que as plantas, em reação a um reduzido 
influxo de ferro, poderiam mudar a composição dos exsudatos radiculares de modo a favorecer o crescimento de microrganismos produtores de sideróforos.

Ainda que esta hipótese não tenha sido provada para o sistema solo-planta-microrganismos, MURPHY et al. (1976) afirmam que a disponibilidade de ferro para absorção microbiana parece ser uma variável importante na determinação da estabilidade e composição microbiana de ecossistemas aquáticos. Segundo esses autores, algas verde-azuladas (ou cianobactérias) dominaram a população de algas de um lago coincidindo com a produção de fortes quelantes de ferro e rápida absorção desse elemento. A maior demanda por ferro parece resultar de altas taxas de fixação biológica do nitrogênio. Anabaena, uma cianobactéria, foi dominante nesses períodos, parecendo ter excretado quelantes que aumentaram o seu próprio crescimento e/ou afetaram diretamente o de espécies compet idoras.

Voltando ao solo, inúmeros sideróforos são lá detectados (AKERS, 1983). Que microrganismos os produzem? A produção de pigmentos fluorescentes é característica de um grupo intra-genérico de Pseudomonas, geneticamente homólogo: $P$. aeruginosa, $P$. putida e $P$. fluorescens. Esses pigmentos, denominados genericamente pioverdinas e cuja síntese é reprimida em meio de cultura pela adição de ferro, são sideróforos (MEYER \& ABDALLAH, 1978). Há outros sideróforos: "pseudobactin" (MACDONALD \& 
Bock, 1987), "ferribactin" produzido por P. fluorescens (PHILSON \& LLINAS, 1982), fusarininas, ferrioxaminas "enterobactin", "aerobactin", "schizokinen", "artrobactin", "agrobactin", ácido rodotorúlico e tioformina (RAYMOND et al., 1984). O próprio nome de alguns desses compostos indica o gênero microbiano que os produzem ou partir do qual foram primeiramente isolados, como fusarininas e "artrobactin", entre outros; tioformina foi isolado tanto de Streptomyces quanto de Pseudomonas. Bactérias do gênero Rhizobium produzem sideróforos (CARRILLO \& VAZQUEZ, 1992)

De ocorrência comum e com habilidade tão especifica como a complexação do ferro, tais compostos devem ter várias funções no solo, sobre as quais pouco se sabe. Na seqüencia serão discutidas com algum detalhe certas funções dos sideróforos no solo.

\subsubsection{Sideroforos e nutrição de plantas}

Como o ferro, mesmo presente no solo em altas concentrações, não está disponível às plantas por estar insolúvel, estas desenvolveram mecanismos de adaptação para mobilizá-lo na rizosfera. Segundo RöMHELd (1987), há poucas formas de aumentar a disponibilidade do ferro às plantas: a) aumentando a redução de $\mathrm{Fe}^{3+}$ a $\mathrm{Fe}^{2+} ;$ b) baixando o pH da rizosfera para favorecer a redução de $\mathrm{Fe}^{3+}$ a $\mathrm{Fe}^{2+}$; c) solubilizando compostos inorgânicos de ferro pouco solúveis por agentes quelantes produzidos pela planta. De 
acordo ainda com o mesmo autor, esses mecanismos separam qualitativamente as plantas como detentoras de duas diferentes estratégias de obtenção do nutriente:

A. Estratégia I, que ocorre na maioria das plantas superiores, isto é, em dicotiledôneas e parte das monocotiledôneas. Essa estratégia apresenta três componentes adaptativos: 1) é induzida pela deficiência de ferro, havendo aumento na redução de $\mathrm{Fe}^{3+}$ a $\mathrm{Fe}^{2+}$ na superfície da raiz, com absorção preferencial da forma divalente; 2) extrusão de $\mathrm{H}^{+}$para reduzir $\mathrm{Fe}^{3+}$ a $\mathrm{Fe}^{2+} ; 3$ ) em certos casos há liberação de substâncias redutoras e/ou quelantes. A redução típica da estratégia I é caracterizada pela ativação de redutases localizadas na membrana plasmática e na parede celular da região apical das raízes. Assim, em deficiência de ferro, plantas de estratégia I aumentam a absorção de ferro a partir de quelatos porque há aumento da atividade de redutases e conseqüente aumento da redução de $\mathrm{Fe}^{3+}$ orgânico a Fe ${ }^{2+}$, isto é, maior taxa de separação do ferro dos quelatos, com maior absorção de $\mathrm{Fe}^{2+}$.

B. Estratégia II, que ocorre em gramíneas. As plantas com essa estratégia liberam fitossideróforos, com certas caracteristicas semelhantes aos sideróforos microbianos já mencionados. Essas plantas têm também um sistema de absorção altamente específico para obter ferro a partir de fitossideróforos (RöMHELD \& MARSCHNER, 1986). Sideróforos de origem vegetal, no entanto, 
não são tão específicos quanto os de origem microbiana: podem quelar outros metais, como cobre, zinco e manganês, sendo que alguns fitossideróforos têm até maior afinidade pelos dois últimos que pelo ferro (TREEBY et al., 1989).

Mesmo assim, RöMHELD \& MARSCHNER (1986) consideram que a estratégia I teria sobre a I a vantagem de não ser inibida em condições de alto valor de pH.

Plantas eficientes em absorver, translocar e/ou utilizar ferro são, pois, as que apresentam uma das duas estratégias de aquisição do nutriente, em contraposição às ineficientes, que não possuem essas estratégias (JOLley \& BROWN, 1991). Doravante, neste trabalho, visando à simplificação, as plantas serão chamadas eficientes ou ineficientes em ferro.

Fitossideróforos podem suprir as necessidades nutricionais de ferro para as plantas que os produzem. Num trabalho com variedades eficientes e ineficientes de milho e aveia, JOLLEY \& BROWN (1991) observaram que, em cultivo conjunto, o fitossideróforo produzido pela aveia eficiente supriu ferro para o milho eficiente, que não liberou fitossideróforos, mas não para o ineficiente. A eficiência do milho, nesse caso, parece ter sido a habilidade em utilizar o fitossideróforo produzido pela aveia. ONYEZILI $\&$ ROSS (1993) sugerem o cultivo intercalado de plantas ineficientes com gramíneas produtoras de fitossideróforos.

$$
\text { Em gramíneas o ferro é absorvido sem o }
$$
envolvimento de processos de redução extracelulares, mas os 
fitossideróforos exsudados podem sofrer degradação por microrganismos rizosféricos (BAR-NESS et a 1., 1992), o que, em certas situações, pode se constituir em desvantagem.

Já as plantas de estratégia I respondem primariamente à deficiência de ferro com a redução de Fe $\mathrm{F}^{3+}$ a $\mathrm{Fe}^{2+}$ pela liberação de $\mathrm{H}^{+}$e por exsudação de substâncias redutoras. Em tomateiro, os sítios de redução de ferro estão predominantemente nas raízes laterais jovens e entre as regiões de elongação da raiz e maturação da raiz primária (BROWN \& AMBLER, 1974). A redução de Fe ja $^{+}$um passo obrigatório na absorção de ferro pelas espécies ef icientes, ocorrendo a redução enzimática provavelmente no plasmalema das células corticais das raízes (RömHELD \& MARSCHNER, 1983 ).

Essa capacidade de redução do $\mathrm{Fe}^{3+}$ parece ser suficiente para suprir as necessidades de plantas de ervilha mas não de Lupinus (WHITE \& ROBSON, 1989), em que deve haver a interferência de outros fatores, uma vez que esta última espécie também promove redução do $\mathrm{Fe}^{3+}$ em sua rizosfera. WHITE \& ROBSON (1990) explicaram as diferenças entre as duas espécies vegetais supondo haver maior controle da distribuição do nutriente na parte aérea da ervilha, presença de um reservatório do elemento no interior das raízes ou conteúdo maior de ferro nas sementes. O ferro poderia acumular-se no apoplasto das raízes tanto das plantas de ervilha quanto de Lupinus, mas, ocorrendo deficiência, ficaria disponível para a parte 
aérea da ervilha mas não de Lupinus.

Sabendo que plantas com diferentes propriedades de mobilização do ferro diferem na quantidade e nas espécies de compostos redutores e quelantes do elemento e que bactérias afetam a exsudação. radicular, MOZAFAR et al. (1992) estudaramo efeito de P. fluorescens sobre a exsudação de açúcares, ácidos orgânicos e aminoácidos pelas raízes de uma variedade de tomate resistente à clorose e de um mutante suscetível. Em condiçōes estéreis as duas variedades cresceram bem e não diferiram na exsudação de açúcares e ácidos orgânicos, embora a variedade resistente tenha exsudado mais aminoácidos, tanto em qualidade quanto em quantidade. Já em presença de $P$. fluorescens o crescimento da variedade resistente não foi afetado mas o crescimento das raízes da variedade suscetível foi estimulado, havendo também grandes alteraçōes na exsudação de açúcares, ácidos orgânicos e aminoácidos. Esses resultados diferenciais, concluem os autores, indicam que as diferenças na suscetibilidade à clorose de ferro podem ser o resultado de interaçōes de raízes e microrganismos rizosféricos ou de modificações resultantes dessas interações.

Comprovação desse fato foi obtida por JURKEVITCH et al. (1988): plantas de amendoim crescendo em solo calcário foram capazes de utilizar o ferro do sideróforo produzido por um isolado de Pseudomonas putida; as plantas assim tratadas tinham $75 \%$ do conteúdo de 
clorofila das plantas que receberam FeEDDHA lácido etileno diamino di-hidróxi) e as não-tratadas, $35 \%$ A clorose induzida por calcário é um problema em Chipre, onde plantaçōes inteiras de amendoim têm suas produções afetadas (PAPASTILIANOU, 1989). Numa tentativa de corrigir o problema, PAPASTILIANOU (1993) aplicou quelato férrico e observou aumento na produção de amendoim até a dose de $8 \mathrm{~g}$ de quelato por metro quadrado, ressaltando ser antieconômico aplicar mais que $4 \mathrm{~g} / \mathrm{m}^{2}$.

Esse tipo de problema não está restrito a Chipre: Costa \& SoUzA (1976) relataram clorose de arroz por deficiência de ferro em vasos com latossolo roxo, em Campinas. Reconhecendo, embora, que essa deficiência não pareça constituir problema para a cultura, os autores sugerem a possibilidade de o elemento ocorrer em quantidades marginais em determinadas condições, causando reduções em produção que não são reconhecidas. Em soja, também no Brasil, o problema já foi detectado no campo, na região do cerrado, em solo com pH em $\mathrm{CaCl}_{2}$ de 6,7 (TANAKA et al., 1989).

Além de Pseudomonas spp., outros microrganismos podem afetar a absorção de ferro mediada por sideróforos: em deficiência de ferro, raizes de Pinus elliot $i$ infectadas por Pisolithus tinctorius aumentarama absorção desse nutriente, o que não ocorreu com as raízes não-micorrizadas (LEYVAL \& REID, 1991). Fungos micorrízicos arbusculares inoculados conjuntamente com uma 
mistura de microrganismos rizosféricos também fizeram aumentar a concentração de ferro na parte aérea de duas espécies cítricas, citrus jambhiri e Poncirus trifoliata (TREEBY, 1992), mas não se definiu se houve envolvimento direto do endófito na nutrição de ferro, por absorção e fornecimento, ou efeito indireto, pelo efeito de aumento do volume de solo explorado pelas raízes.

2.2.3. Sideróforos e controle biológico

Segundo a literatura, RPCPs produtoras de sideróforos podem promover o crescimento vegetal também pelo controle biológico de fitopatógenos. Logo depois de cunhar a expressão "RPCPs", o mesmo grupo de pesquisadores publicou trabalho afirmando que a promoção de crescimento proporcionada pelas bactérias fluorescentes do gênero Pseudomonas é por privar de ferro a microbiota nativa (KLOEPPER et a l., 1980). De acordo com tal hipótese, as RPCPs inoculadas colonizariam rapidamente a rizosfera; havendo pouco ferro disponível no rizoplano as bactérias produziriam sideróforos que complexariam o nutriente e o tornariam indisponível para outros microrganismos. Nesse trabalho, os autores relatam a inibição de Erwinia carotovora por isolado fluorescente de Pseudomonas spp. em meio de cultura; um mutante não-fluorescente do mesmo isolado, e portanto não-produtor de sideróforo, não inibiu o patógeno. A confrontação entre o patógeno e o pigmento, 
pseudobactin, contido em discos de papel, também resultou em antagonismo, mas a adição de Fe-pseudobactin não promoveu o crescimento de plantas, o que fez com que os autores descartassem a hipótese do envolvimento dos sideróforos na nutrição vegetal. A competição por nutrientes com patógenos também é considerada por SIMEONI et a l. (1987): um isolado de Pseudomonas putida diminuiu significativamente, "in vitro", a germinação de clamidosporos de um patógeno, Fusarium oxysporum f. sp. cucumerinum, enquanto que um mutante não-produtor de sideróforo não afetou a germinação dos clamidosporos. Em contrapartida, em presença de ferro disponível, o isolado de $P$. putida não afetou a germinação do fungo.

Outro patógeno, F. oxysporum f. sp. lini necessita de ferro para a elongação de seu tubo germinativo, que foi inibida por um isolado de P. putida, em trabalho apresentado por SCHER \& BAKER (1982). Quando esse isolado, obtido originalmente de um solo supressivo à murcha de Fusarium, foi juntado a um solo condutivo este se tornou supressivo; o mesmo efeito foi obtido com EDDHA ou FeEDDHA .

O efeito sobre a germinação de propágulos de patógenos pode variar com o pH do solo, sendo mais significativo em solos neutros ou alcalinos e menos significativo em valores menores de pH (PARK et al., 1988). Outros fatores podem afetar a produção de sideróforos no solo, o que explicaria, pelo menos em parte, uma certa 
inconsistência em experimentos com RPCPs. Numa tentativa de elucidar essa variabilidade de resultados, KIM \& MISAGHI (1992) estudaram o efeito das concentrações de $\mathrm{O}_{2}$ e $\mathrm{CO}_{2}$ sobre a produção de sideróforos: preparando várias atmosferas, com concentrações variadas de $\mathrm{O}_{2}, \mathrm{CO}_{2}$ e $\mathrm{N}_{2}$, observaram que a produção de sideróforos diminuiu com baixas tensões de oxigênio, principalmente quando associadas a altas tensões de $\mathrm{CO}_{2}$. O efeito desses gases tanto pode ocorrer diretamente sobre o crescimento bacteriano quanto especificamente sobre a produção de sideróforos. Como em solos cultivados as concentrações de $\mathrm{O}_{2}$ e $\mathrm{CO}_{2}$ variam com a temperatura, umidade, conteúdo de matéria orgânica, tipo de cultura e atividade respiratória de raízes e microrganismos, podendo $\mathrm{O}_{2}$ representar menos de $10 \%$ do total de gases no solo e o $\mathrm{CO}_{2}$ mais de $10 \%$, os autores mencionam algumas aplicações práticas de seu trabalho: devem ser adotadas práticas culturais que ajudem a aumentar as trocas gasosas entre solo e atmosfera bem como as que ajudem a diminuir o excesso de umidade, como por exemplo, a aração profunda e a adição de materiais que reduzam a compactação do solo. KIM \& MISAGHI (1992) lembram a inda outra conseqüência de sua descoberta: como a taxa $\mathrm{O}_{2} / \mathrm{CO}_{2}$ diminui com a profundidade, o controle biológico por Pseudomonas spp. produtoras de sideróforos pode ser mais eficiente contra fungos que ataquem mais superficialmente, como Pythium, que contra outros, mais prejudiciais em camadas mais profundas do solo. BECKER \& 
COOK (1988) conseguiram o controle de Pythium ultimum var. sporangi iferum em trigo com o envolvimento de sideróforos produzidos por Pseudomonas spp. e dizem, textualmente: "o controle de Pythium spp. tem a aparência de que o crescimento das plântulas foi estimulado pelo tratamento quando, na verdade, as plântulas estão mais próximas de seu potencial total de crescimento". Sobre isso lembram ainda que os fungos do gênero Pythium são ubíquos e têm efeito sutil mas significativo no crescimento das plântulas.

Neste ponto, é pertinente lembrar a existência dos patógenos "menores" ou "subclínicos". Tais patógenos, não vivendo no interior das plantas, produzem toxinas que afetariam o crescimento vegetal, com ou sem a manifestação de sintomas visíveis (WOLTZ, 1978). A at ividade desses patógenos menores poderia resultar em diminuição no crescimento da planta que, na ausência de plantas não-afetadas, poderia passar despercebido. Assim, a eliminação desses patógenos menores, por RPCPs ou outra forma qualquer, pareceria resultar em promoção do crescimento da planta quando, de fato, ela só estaria expressando seu potencial de crescimento mais realisticamente. Abrindo um parêntesis, esse efeito poderia explicar muitos benefícios de RPCPs de causa ainda não determinada.

Em que pesem tantos trabalhos apontando o papel dos sideróforos no controle de fitopatógenos por Pseudomonas spp. há quem deles discorde. Tendo observado 
grande variação na produção de sideróforos em função do pH de diversos solos, MISAGHI et al. (:9SS) consideraram que a competição por ferro entre Pseudomonas e patógenos pode estar limitada, no campo, a alguns poucos casos em que o pH e provavelmente outros fatores sejam adequados não só à produção de sideróforos mas também à sua atividade. A supressão de doenças por Pseudomonas spp. fluorescentes pode ser devida a antibiose, competição por outros elementos essenciais, com envolvimento até de sideróforos não-fluorescentes, e por outros mecanismos desconhecidos. HANDAN et al. (1988) trabalharam com um isolado de $P$. fluorescens que é antagônico a Gaeumannomyces graminis var. tritici, patógeno de trigo, e que produz um sideróforo e um antibiótico. Tanto em solo com valor de $\mathrm{pH}$ de 7,6 quanto em outro com valor de $\mathrm{pH}$ de 5,5 foi o antibiótico que causou as reduções mais significativas da doença, com pequena contribuição do sideróforo. Num experimento "in vitro" com o mesmo isolado de P. fluorescens BRISBANE et a 1. (1989) relataram que o antibiótico inibiu dezessete dos 22 fungos testados mas que o sideróforo não inibiu nenhum.

\subsubsection{Sideróforos: outros aspectos}

\footnotetext{
$\mathrm{Na}$ Holanda, ocorrem diferenças de produtividade de batatas cultivadas em dois sistemas de manejo. No sistema denominado "rotação curta", em que o cultivo da batata é mais freqüente num mesmo terreno, há
} 
diminuição progressiva da produção com o cultivo enquanto que no sistema de "rotação longa", de cultivo menos freqüente, esse problema não ocorre (BAKkER \& SCHIPPERS, 1987). Embora não se observem danos ou sintomas de doenças, há menor produção em cultivo freqüente, parecendo que esse decréscimo na produção é causado por prejuízo ao funcionamento das raízes, ocasionado por microrganismos, e não por dano direto, causado por patógenos regulares. BAKKER \& SCHIPPERS (1987), num trabalho partindo da hipótese de dano ao funcionamento das raízes, verificaram que cerca de $50 \%$ das bactérias do gênero Pseudomonas encontradas em rizosfera de batata produzem HCN "in vitro" e que $5 \mu$ de HCN foram suficientes para inibir em $40 \%$ a respiração da citocromo oxidase em raizes de batata "in vitro". A produção de cianeto "in vitro" depende da concentração de $\mathrm{Fe}^{3+}$ no meio e não foi detectada em dois isolados de Pseudomonas spp. sabidamente promotores do crescimento de batata. Partindo desses resultados, os autores sugerem que o cianeto seja o causador da diminuição de produção. Nesses casos, RPCPs aumentariam o crescimento competindo por $\mathrm{Fe}^{3+}$ com microrganismos produtores de HCN.

Essa hipótese é confirmada por BAKKER et al. (1987), que observaram maior desenvolvimento de raízes de batata em rotação curta quando inoculada com um isolado de P. fluorescens e um de P. putida. Os mutantes nãoprodutores de sideróforos não tiveram esse efeito, indicando ser esse um pré-requisito para a promoção de 
crescimento.

Partindo desses resultados, BAKKER \& SCHIPPERS (1987) quantificaram microrganismos produtores de HCN e Pseudomonas spp. fluorescentes, potencialmente promotores de crescimento, em rizosfera de batata em solos com curta e longa rotação, e, surpreendentemente, não encontraram diferenças significativas. Aventaram então a hipótese de o aumento na produção de cianeto não necessariamente depender do aumento no número de produtores: poderia ser devido a uma alteração no metabolismo secundário de produtores potenciais, havendo uma gradação de produção desde pouco ou nenhum HCN a té uma produção máxima. A produção de $\mathrm{HCN}$ por Pseudomonas spp. varia com fatores ambientais, dos quais um ou mais podem ser diferentes em solos de cultivo mais ou menos freqüente de batata. Ou então poderiam ocorrer, por algum motivo, produtores mais eficientes de sideróforos antagônicos em solos de rotação longa e/ou produtores mais eficientes de HCN em solos de rotação curta.

Em sentido diverso foram as pesquisas de KELL et a l. (1989): um isolado de P. fluorescens que suprimiu a podridão preta de raiz de tabaco, causada por Thielaviopsis basicola, produziu HCN "in vitro". O interessante é que tanto esse isolado, produtor de sideróforo, quanto um seu mutante, não-fluorescente, controlaram a doença, desde que houvesse ferro disponível para o mutante. Isso indica que o sideróforo não esteve envolvido na supressão da doença, 
mas, em outros testes, os autores verificaram que as bactérias necessitam de ferro para a produção de HCN. A capacidade dos isolados, parental e mutante, de suprimir a doença em diferentes sistemas controlados correlacionou-se com a sua capacidade de produzir HCN em grandes quantidades em meio de cultura.

\subsection{Produção de antibióticos}

Muito freqüentemente bactérias são citadas como tendo atividade antagônica a fungos. Testes "in vitro", confrontando dois organismos na mesma placa de Petri, por exemplo, permitem o teste de grande número de agentes e patógenos. GANESAN \& GNANAMANICKAM (1987) obtiveram inibição "in vitro" de sclerotium rolfsii por Pseudomonas fluorescens; em casa de vegetação, $99 \%$ das plantas de amendoim inoculadas com ambos os organismos não chegaram a desenvolver doença, enquanto que todas as inoculadas apenas com $S$. rolfsii murcharam ou morreram.

Resultados positivos também foram relatados, em escala bem maior, por GAMLIEL \& KATAN (1993), com P. putida, P. fluorescens e P. alcaligenes antagonizando $S$. rolfsii em feijão e Penicilium pinophilum, um patógeno menor de tomateiro e algodoeiro, em solo solarizado. Em tomateiro em casa de vegetação, já se conseguiu também reduzir a incidência da murcha causada por Fusarium oxysporum f. sp. lycopersici com a inoculação de 
Pseudomonas spp. (FREITAS \& PIZZINATTO, 1991).

Além do controle propiciado pelos sideróforos, já comentado, a redução na incidência de doenças pode ser creditada à produção de antibióticos por Pseudomonas fluorescentes. ELAD \& CHET (1987) reduziram a ocorrência de "damping-off" causado por Pythium em abóbora, a lgodão, feijão, melão, pimenta e tomate, excluindo a possibilidade de o controle ter sido feito por sideróforos, uma vez que o valor do $\mathrm{pH}$ do substrato era de 6 , onde o ferro está disponível. outra maneira de provar, indiretamente, que os sideróforos não têm papel no controle de certas doenças é com o uso de mutantes não-produtores de sideróforos: tanto o isolado mutante quanto o parental de P. putida controlaram a ocorrência de "damping-off" de Pythium em abóbora (PAULITZ \& LOPER, 1991).

Em outros trabalhos apresentam-se provas diretas do envolvimento de antibióticos: Howel \& STIPANOVIC (1980) purificaram um antibiótico, "pyoluteorin", que inibiu "in vitro" o crescimento de Pythium ultimum; em vasos, tanto o antibiótico quanto a inoculação da bactéria que o produziu, P. fluorescens, reduziram a incidência da doença causada pelo fungo.

Há vários trabalhos com o isolado 2-79 de $P$. fluorescens, produtor do antibiótico ácido fenazina-1-carboxílico, cujo papel parece estar bem estabelecido no controle do mal-do-pé de trigo, causado por Gaeumannomyces graminis var. tritici (THOMASHOW et al., 1988, PIERSON III 
\& THOMASHOW, 1988 e BLLL et al., 19911. Pseudomonas aureofaciens, produtor de outro antibiótico, também inibiu o crescimento "in vitro" e "in vivo" do fungo causador do mal-do-pé (HARRISON et al., 1993).

Outros trabalhos mencionam o envolvimento de antibióticos produzidos por $P$. fluorescens na inibição de patógenos, como fusarium oxysporum f. sp. apii em aipo (ZIEGLE \& CORRELL, 1988), F. oxysporum f. sp. cubense em banana (SIVAMANI \& GNANAMANICKAM, 1988) e F. moniliforme "in vitro" (HEBBAR et al., 1992a e b).

$$
\text { Nem só Pseudomonas spp. pröuzem }
$$

antibióticos. Aliás, há relatos mais antigos sobre a produção de antibióticos por outros gêneros. DUNLEAVY (1955) conseguiu o controle de Rhizoctonia sp. em beterraba pela inoculação de Bacillus subtilis; observou ao microscópio, após cultivo conjunto, "in vitro", dos dois organismos, que a bactéria inibiu o crescimento lateral das hifas fúngicas. Esses efeitos foram causados por um antibiótico, cujo isolamento também é mencionado no trabalho.

Outra espécie bacteriana, Serratia marcescens, inibe o crescimento de sclerotium rolfsii pela produção de uma enzima quitinolítica que degrada as paredes da hifas do fungo (ORDENTLICH et al., 1988). 
2.4. Rizobactérias deletérias

E preciso lembrar que há várias espécies de Pseudomonas que são patógenos de há muito conhecidos. Também as há agindo de forma a diminuir a produção de certas culturas de forma menos evidente, levando-se às vezes muito tempo para relacioná-las aos problemas que acarretam.

Em trigo, já se relacionou a ocorrência, na rizosfera, de bactérias do gênero Pseudomonas com decréscimos de produção ocasionados pelo cultivo contínuo num mesmo local, havendo correlação entre a diminuição de produção e a intensidade de colonização das raízes pelas bactérias (FREDRICKSON \& ELLIOTT, 1985). Fatores do ambiente podem influenciar o efeito das bactérias: ELLIOTT \& LYNCH (1984) observaram que as baixas produções de trigo foram mais acentuadas em locais onde a semeadura foi feita diretamente, com resíduos do cultivo anterior, ou onde o residuo havia sido incorporado; nos locais em que se procedeu à queima dos restos culturais, as produções foram maiores, ocorrendo então menor colonização das raízes por Pseudomonas spp. O efeito inibitório das bactérias parece ser devido a toxinas (CHERRINGTON \& ELLIOTT, 1987), que inibiram o crescimento das raízes, fato observado em trigo (CHERRINGTON \& ELLIOTT, 1987 e BOLTON JT . \& ELLIOTT, 1989), cevada, ervilha e lentilha (CHERRINGTON \& ELLIOTT, 1987). BOLTON Jr. \& ELLIOTT (1989) fizeram mesmo uma interessante 
correlação entre a toxicidade de alguns isolados de Pseudomonas spp. a raízes de trigo e a Escherichia coli. Mais de $90 \%$ dos isolados que inibiram o crescimento de raízes de trigo também inibiram o de $E$. coli, fato que os autores consideram útil para teste rápido de detecção de rizobactérias deletérias. Todavia, em nenhum dos trabalhos com rizobactérias inibitórias citados as bactérias pertenciam ao grupo fluorescente de Pseudomonas spp.

2.5. Interações de micorrizas e microbiota rizosférica - Com raras exceções, plantas micorrizadas ocorrem como regra em campos de cultivo agrícolas. Assim, rigorosamente falando, o que se tem não é uma rizosfera mas uma "micorrizosfera". Essa micorrizosfera é que exercerá seu próprio efeito seletivo sobre as atividades microbianas no solo circunjacente (GRAHAM, 1988), alterando-se inclusive a quantidade de exsudatos radiculares liberados para o solo (GRAHAM et al., 1981). A influência sobre a microbiota micorrizosférica seria exercida principalmente pela quantidade e qualidade desses exsudatos.

Inversamente, a comunidade rizosférica interage de diversas maneiras com fungos micorrízicos, podendo afetar seu estabelecimento na raiz (AMES et al., $1984)$.

AZCON-AGUILAR \& BAREA (1985) relatam que uma mistura de microrganismos isolados do solo influenciou 
favoravelmente a formação de micorriza por Glomus mosseae e Medicago sativa, atribuindo esse efeito a um aumento do crescimento das hifas fúngicas, propiciado pela microbiota inoculada, nos estádios de pré-infecção. Microrganismos rizosféricos também podem estimular a germinação de esporos de G. mossae (AZCÓN-AGUILAR et al., 1986).

A comunidade micorrizosférica de Pseudomonas fluorescentes já foi diminuída, em relação a plantas não-micorrizadas de milho e trevo subterrâneo, em presença do fungo G. fasciculatum (MEYER \& LINDERMAN, 1986b). Tentando elucidar os motivos desse efeito, PAULITZ \& LINDERMAN (1989) fizeram inoculações conjuntas de isolados de P. putida e P. fluorescens e Glomus intraradices e $G$. etunicatum em abóbora. No início do crescimento das plantas quase todos os isolados de Pseudomonas tiveram sua população diminuída em presença de $G$. intraradices mas não de G. etunicatum. Dois isolados bacterianos, por sua vez, já conhecidos como produtores de antibióticos, atrasaram a germinação de esporos de G. etunicatum. Como $G$. intraradices coloniza as raízes mais rapidamente que $G$. etunicatum, atribuiu-se o efeito negativo do primeiro fungo sobre a população de Pseudomonas à competição entre ambos por produtos fotossintetizados num período em que a planta os produz em pequena quantidade. Como G. etunicatum é um colonizador mais lento, essa competição não existiria e portanto não haveria influência sobre a população de Pseudomonas. 
2.6. Inconsistência no uso de RPCPs

E muito comum a citação, em artigos cientificos, de problemas ou falhas no emprego de RPCPs (HEBBAR et al., 1992a) sendo essa uma das mais sérias $1 \mathrm{imitações} \mathrm{ao} \mathrm{seu} \mathrm{emprego} \mathrm{em} \mathrm{maior} \mathrm{escala.} \mathrm{As} \mathrm{razões} \mathrm{desta}$ inconsistência dependerão, é claro, do modo de ação da RPCPs em cada caso específico.

Atribuindo essa inconsistência à baixa colonização das raízes pelas bactérias, HEBBAR et al. (1992b) observaram que a colonização das raízes de milho por Pseudomonas cepacia variou com a esterilização do solo: em solo esterilizado, um isolado da bactéria colonizou melhor as raízes do que outro, mas em solo natural a situação se inverteu. Foram arroladas algumas características para que um isolado de bactéria possa ser considerado um bom inoculante microbiano: a) alta população no solo, que poderia ser favorecida por práticas culturais; b) altas taxas de crescimento; c) resistência a antibioticos; d) alta habilidade competitiva.

Pensando especificamente na inconsistência de tentativas de controle biológico com RPCPs, WELLER \& ZABLOTOWICZ (1987) mencionam, além da variabilidade na colonização radicular, o fato de que as condições ambientais podem desfavorecer a ocorrência da própria doença, resultando em que se note promoção de crescimento, particularmente quando a doença em questão for causada por 
patógenos menores. Num outro extremo, pode ocorrer que outros patógenos também estejam agindo, além daquele que se tem em vista. Igualmente, o método de inoculação pode ter papel na determinação do sucesso de um promotor de crescimento em potencial.

Ainda quanto a agentes de controle biológico, a seleção de antagonistas é ponto crucial. Freqüentemente se considera que o desempenho "in vivo" não se correlaciona com a seleção de isolados "in vitro" (SCHIPPERS \& LUGTENBERG, 1987). Ainda que houvesse essa correlação, KLOEPPER (1991) lembra que os métodos de seleção "in vitro" selecionam apenas os agentes eficientes por produção de antibióticos, metabólitos tóxicos e sideróforos e não consideram os que agem por competição, parasitismo ou resistência induzida.

Contudo, há quem defenda a seleção "in vitro": SIVAMANI \& GNANAMANICKAM (1988) utilizaram isolados de P. fluorescens previamente selecionados, "in vitro", como antagônicos a Fusarium oxysporum f. sp. cubense e conseguiram redução na incidência da doença conhecida como "mal do Panamá" em banana. Os autores justificaram o uso de testes "in vitro" como método de seleção citando vários trabalhos do próprio grupo (Ganesan \& Gnanamanickam, 1987; Sarthicul \& Gnanamanickam, 1986 e Savithiry \& Gnanamanickam, 1987) em que se observou correlação entre o antagonismo "in vitro" e "in vivo". 
3. MATERIAL E MÉTODOS

3.1. Obtenção dos isolados

Os isolados de Pseudomonas spp. foram obtidos em campos com histórico de cultivo da mesma espécie vegetal há pelo menos dois anos. Foram escolhidas sempre plantas vigorosas, sem sintomas de deficiências minerais ou doenças. Arrancaram-se cinco plantas de cada espécie vegetal, suas raízes foram separadas, agitadas para desprendimento do solo mais frouxamente aderido e mergulhadas em frascos de Erlenmeyer contendo água esterilizada. Depois de agitados os frascos por dez minutos em agitador mecânico, alíquotas de $0,1 \mathrm{ml}$ da suspensão de solo foram espalhadas em placas de Petri com meio B de KING et al. (1954) e as placas foram mantidas a $30^{\circ} \mathrm{C}$ por $24 \mathrm{~h}$. A seguir colocaram-se as placas sob luz com comprimento de onda próximo do ultravioleta. As colônias que apresentaram pigmentação fluorescente foram transferidas para tubos de ensaio com água esterilizada. Agitaram-se os tubos em agitador rotativo e transferiram-se a líquotas de $0,1 \mathrm{ml}$ da suspensão neles contida para placas com meio B de KING at al. (1954), doravante designado "meio B". Foram feitas diluições e plaqueamentos 
sucessivos até serem obtidas colônias isoladas com aspecto macroscópico uniforme em toda a placa.

Para a obtenção de isolados de Bacillus spp. o processo de seleção das plantas foi semelhante. Depois da agitação das raízes em água, as mesmas foram retiradas e a suspensão foi mantida em banho-maria a $80^{\circ} \mathrm{C}$ por 20 minutos. Amostras de dez gramas solo não-rizosférico e de turfa para produção de inoculante para leguminosas também sofreram o mesmo tratamento. Espalharam-se alíquotas de $0,1 \mathrm{ml}$ da suspensão assim tratada em placas com meio de batata-dextrose-ágar (BDA) incubadas a $28^{\circ} \mathrm{C}$ por $48 \mathrm{~h}$. As colônias obtidas sofreram diluições e plaqueamentos sucessivos até se obterem colônias isoladas com o aspecto macroscópico uniforme.

Fez-se o teste de Gram em todos os isolados obtidos, confirmando-se o resultado Gram negativo para os de Pseudomonas e positivo para os de Bacillus. Nestes últimos confirmou-se também a presença de endosporo, pelo exame microscópico com técnica de coloração com verdemalaquita.

Os isolados de Pseudomonas foram mantidos em meio $B$ e os de Bacillus, em BDA, em geladeira, sob óleo mineral.

Oito isolados de Pseudomonas spp. utilizados por BRANDÃO (1989) foram também incluídos nos testes.

A origem e a designação de todos os isolados estão detalhadas na Tabela 1 . 
Tabela 1. Origem dos isolados bacterianos utilizados

\begin{tabular}{|c|c|}
\hline Isolados & Origem \\
\hline \multicolumn{2}{|l|}{ Pseudomonas spp ${ }^{(1)}$} \\
\hline $\begin{aligned} \text { Ps-21-A, } & 21-B, \quad 21-C, \\
22-A, & 22-B, \\
23-A, & 23-B, 23-C .\end{aligned}$ & $\begin{array}{l}\text { Rizosfera de algodoeiro } \\
\text { hirsutum) cv. IAC } 20 .\end{array}$ \\
\hline $\begin{array}{l}\text { Ps- } 31-A, 31-B, 31-C, 31-D, \\
32 \\
33 \\
34-A, 34-B, 34-C .\end{array}$ & $\begin{array}{l}\text { Rizosfera de plantas de milho (Zea mays) } \\
\text { variedade } 111-\mathrm{S} \text { (Cargill). }\end{array}$ \\
\hline $\begin{array}{l}\text { Ps-41-A, } 41-B, 41-C, \\
42-A, 42-B, 42-C, \\
43-A, 43-B, 43-C, \\
44-A, 44-B .\end{array}$ & $\begin{array}{l}\text { Rizosfera de plantas de soja (Glycine } \\
\text { max) cultivar IAS-5. }\end{array}$ \\
\hline $\begin{aligned} \text { Ps-51-A, } & 51-\mathrm{B}, \\
52-\mathrm{A}, & 52-\mathrm{B}, \\
53-\mathrm{A}, & 53-\mathrm{B}, 53-\mathrm{C}, \\
54-\mathrm{A}, & 54-\mathrm{B}, 54-\mathrm{C} .\end{aligned}$ & $\begin{array}{l}\text { Rizosfera de tomateiro (Lycopersicon } \\
\text { esculentum) cultivar TOM- } 3030 .\end{array}$ \\
\hline $\begin{aligned} \text { G20-18 - } & \text { Pseudomonas } \\
& \text { fluorescens }\end{aligned}$ & $\begin{array}{l}\text { J.W. Kloepper, Allelix Inc., Canadá, } \\
\text { através da ESALQ/USP. }\end{array}$ \\
\hline $136 \mathrm{RN}$ & $\begin{array}{l}\text { Rizosfera de plantas de milho (BRANDÃO, } \\
\text { 1989). }\end{array}$ \\
\hline $\begin{array}{l}\text { W4F-35, } 58,111,164- \\
-P . \text { fluorescens }\end{array}$ & $\begin{array}{l}\text { D.C. Gross, washington State University, } \\
\text { EUA, através da ESALQ/USP. }\end{array}$ \\
\hline W4P-5, $144-P$. putida & $\begin{array}{l}\text { D.C. Gross, washington State University, } \\
\text { EUA, através da ESALQ/USP. }\end{array}$ \\
\hline \multicolumn{2}{|l|}{ Bacillus spp. (2) } \\
\hline $\mathrm{A} 1 \mathrm{~A}, \mathrm{~A} 2 \mathrm{~A}, \mathrm{~A} 3 \mathrm{~A}, \mathrm{~A} 4 \mathrm{~A}$ & Rizosfera de algodoeiro. \\
\hline $\mathrm{C} 2 \mathrm{~A}, \mathrm{C} 2 \mathrm{~B}, \mathrm{C} 3 \mathrm{~B}$ & Rizosfera de cafeeiro (Coffea arabica). \\
\hline $\mathrm{D} 1 \mathrm{~A}, \mathrm{D} 1 \mathrm{~B}, \mathrm{D} 1 \mathrm{C}$ & Solo não-rizosférico. \\
\hline E1B & $\begin{array}{l}\text { Turfa para produção de inoculante para } \\
\text { leguminosas. }\end{array}$ \\
\hline $\mathrm{M} 1 \mathrm{~B}, \mathrm{M} 2 \mathrm{~B}, \mathrm{M} 5 \mathrm{C}$ & Rizosfera de plantas de milho. \\
\hline $\mathrm{S} 4 \mathrm{~B}, \mathrm{~S} 5 \mathrm{~A}$ & Rizosfera de plantas de soja. \\
\hline
\end{tabular}


3.2. Solo

Utilizaram-se amostras do mesmo solo em todos os experimentos, um latossolo vermelho-amarelo do centro Experimental de Campinas do Instituto Agronômico, mantido em pousio. Esse solo havia recebido, no campo, incorporação de calcário de modo a elevar seu pH.

A análise do solo apresentou os seguintes resultados: $\mathrm{P}(\mathrm{ppm}), 20$; matéria orgânica $(\%), 3,9 ; \mathrm{pH}\left(\mathrm{CaCl}_{2}\right)$, 6,$3 ;$ em meq/ $100 \mathrm{~cm}^{3}: \mathrm{K}, 0,39 ; \mathrm{Ca}, 4,2 ; \mathrm{Mg}, 3,6 ; \mathrm{H}+\mathrm{Al}, 1,6$; $\mathrm{S}, 8,2 ; \mathrm{T}, 9,8 ; \mathrm{V}(\%), 84$.

A esterilização do solo, com radiação gama, foi feita pela empresa IBRAS (Campinas, SP), usando a dose de 2,5 Mrad.

A mistura de 2 partes de solo e 8 partes de areia, usada no experimento com feijão, foi fumigada com brometo de metila, na dose de $260 \mathrm{~cm}^{3} / \mathrm{m}^{3}$ da mistura. O valor de $\mathrm{pH}$ da mistura foi de 5,6 em $\mathrm{CaCl}_{2}$.

\subsection{Experimento com feijão}

Para verificar se RPCPs exercem benefício por interagirem com micorrizas, usou-se como modelo o sistema formado pela inoculação conjunta de plantas de feijão (Phaseolus vulgaris) com fungos micortízicos (SILVEIRA \& CARDóso, 1987), com bactérias fluorescentes e com fixadores simbióticos de nitrogênio. 
Usou-se a variedade IAC-Carioca de feijão, cultivada em vasos plásticos com capacidade de $500 \mathrm{ml}$ com mistura brometizada de solo e areia (item 3.2).

O delineamento estatístico seguiu o esquema fatorial $3 \times 17$, sendo três tratamentos de inoculação de fungo micorrízico (uma testemunha não-inoculada, um tratamento de inoculação com Glomus etunicatum e um de inoculação com scutellospora heterogama) e dezessete de inoculação com Pseudomonas spp. (uma testemunha nãoinoculada e dezesseis tratamentos de inoculação com os isolados Ps-21-A, 21-B, 21-C, 22-A, 22-B, 23-A, 23-B, 23-C, $31-\mathrm{A}, 31-\mathrm{B}, 31-\mathrm{C}, 31-\mathrm{D}, 32,33,34-\mathrm{A}$ e $34-\mathrm{B})$.

Os vasos com inoculação de G. etunicatum receberam $5 \mathrm{ml}$ de solo-inóculo, contendo 1.500 esporos do fungo e pedaços de raiz infectada. Na inoculação com $S$. heterogama o solo-inóculo continha, além dos pedaços de raiz, 1.700 esporos do fungo. Os vasos da test.emunha receberam $10 \mathrm{ml}$ de uma suspensão do mesmo solo filtrada para retirar propágulos de fungo micorrízico. O inóculo dos fungos foi colocado a $5 \mathrm{~cm}$ de profundidade em relação à superfície do vaso e coberto com $2 \mathrm{~cm}$ do substrato. A inoculação das bactérias foi feita pela adição de $10 \mathrm{ml}$ de meio B líquido em que os isolados cresciam há 72 horas. A testemunha não-inoculada recebeu $10 \mathrm{ml}$ do meio $B$ esterilizado.

Cada vaso recebeu quatro sementes, desbastando-se dez dias depois da semeadura para deixar uma 
planta por vaso. Por ocasião do desbaste fez-se a inoculação de todas as plantas com Rhizobium leguminosarum bv. phaseoli, estirpes recomendadas SMS-731 e SMS-463, adicionando-se $10 \mathrm{ml}$ de meio YMB com crescimento das bactérias por vaso.

Os vasos foram mantidos em casa de vegetação, em esquema inteiramente casualizado, com quatro repetições por tratamento.

As plantas receberam irrigação com a solução nutritiva descrita por FAQUIM (1988), $50 \mathrm{ml} / \mathrm{vaso}$, aos 14 , 27 e 38 dias após a semeadura, modificando a concentração de fósforo para $1 / 20$ da solução normal e não se juntando ferro à solução de micronutrientes. A colheita foi feita 47 dias após a semeadura separando-se parte aérea e raízes. Foram analisadas as seguintes variáveis: massa de matéria seca de parte aérea, raízes e nódulos, conteúdos de nitrogênio e fósforo na parte aérea (SARRUGE \& HAAG, 1974) e colonização radicular pelos fungos micorrízicos (AMBLER \& YOUNG, 1977 e PHILIPPS \& HAYMAN, $1970)$

\subsection{Experimento com mi tho}

Plantas de milho (Zea mays) inoculadas com bactérias fluorescentes constituíram um dos modelos para teste da possibilidade de interação de RPCPs com fi topatógenos. 
O delineamento estatístico seguiu o esquema fatorial, com dois tratamentos de esterilização de solo (solo esterilizado e solo natural) e 4? tratamentos de inoculação de Pseudomonas (uma testemunha não-inoculada e os 46 isolados de Pseudomonas spp. relacionados na Tabela 1, it em 3.1).

A esterilização do solo foi por radiação gama. Para a inoculação com as bactérias as sementes de milho foram embebidas por duas horas em meio B líquido em que cada isolado crescia há 48 horas. A seguir foram colocadas cinco sementes em cada vaso de $500 \mathrm{ml}$ de capacidade, com $0,5 \mathrm{~kg}$ de amostra de solo. Depois de as sementes serem cobertas, cada vaso recebeu $10 \mathrm{ml}$ do isolado correspondente. Dez dias depois da semeadura procedeu-se ao desbaste para deixar uma planta por vaso. Os vasos foram mantidos em casa de vegetação, em delineamento inteiramente casualizado, com quatro repetições por trat amento.

Semanalmente todas as plantas receberam $30 \mathrm{ml}$ da solução proposta por FAQUIM (1988), exceto pela aplicação de ferro, que não foi feita.

A colheita, separando-se parte aérea e raízes, foi feita cinqüenta dias após a semeadura, sendo obtidas as massas de matéria seca. 
3.5. Experimento com tomateiro

\begin{abstract}
A semelhança do milho, plantas de tomate (Lycopersicon esculentum) também foram usadas como modelo para estudo da interação de RPCPs com fitopatógenos. Seguiu-se o mesmo esquema básico já descrito no item 3.4. para o experimento com milho. Na inoculação foram utilizados os 46 isolados de Pseudomonas spp. e dezesseis de Bacillus spp. relacionados na Tabela 1 , num total de 63 tratamentos de inoculação (considerando-se a testemunha não-i noculada).
\end{abstract}

A variedade de tomateiro usada foi a Santa Clara. Cada vaso recebeu cinco sementes; uma semana depois procedeu-se ao desbaste para deixar uma planta por vaso.

Uma semana antes da semeadura misturou-se adubo sólido à terra dos vasos nas seguintes quantidades: $400 \mathrm{mg}$ de $\mathrm{P}$, fornecido como $\mathrm{KH}_{2} \mathrm{PO}_{4}$ e como superfosfato simples, e $200 \mathrm{mg}$ de $\mathrm{K}$, fornecido como $\mathrm{KH}_{2} \mathrm{PO}_{4}$. O nitrogênio foi aplicado em três vezes, num total de $200 \mathrm{mg}$ aplicados $1 / 3$ na semeadura, $1 / 3$ uma semana depois e $1 / 3$ outra semana depois, na forma de solução de $\mathrm{NH}_{4} \mathrm{NO}_{3}$. Na aplicação de micronutrientes não se incluiu o ferro.

A. colheita, separando-se parte aérea e raízes, foi feita quarenta dias após a semeadura, obtendose as massas de matéria seca. 
3.6. Experimentos com soja

A possibilidade de RPCPs produtoras de sideróforos atuarem no fornecimento de ferro a plantas deficientes no nutriente foi estudada adotando-se como modelo plantas de três cultivares de soja (Glycine max) inoculadas com isolados fluorescentes de Pseudomonas spp.

\subsubsection{Cultivar Santa Rosa}

Neste experimento, com uma cultivar tida como eficiente em ferro, seguiu-se o mesmo esquema básico já descrito para o experimento com milho (item 3.4).

A inoculação de bactérias foi feita com os 46 isolados de Pseudomonas spp. relacionados na Tabela 1.

Procedeu-se à colheita, separando-se raízes e parte aérea, 45 dias após a semeadura, obtendo-se a seguir as massas de matéria seca.

\subsubsection{Cultivar Santa Rosa Clorose}

As sementes dessa cultivar, à semelhança das outras de soja, foram fornecidas pelo pesquisador Manoel Albino Coelho de Miranda, da Seção de Leguminosas do Instituto Agronômico. A cultivar Santa Rosa Clorose foi obtida por cruzamento da cultivar Santa Rosa com a T-203, 
cultivar americana ineficiente em ferro (MIRANDA ${ }^{1}$ ). A cultivar Santa Rosa Clorose apresenta, pois, características semelhantes à Santa Rosa, exceto pelo fato de apresentar deficiência de ferro quando cultivada em solo com valor de pH próximo da neutralidade.

Neste experimento, os vasos tinham cerca de $10 \mathrm{~kg}$ de solo e não houve tratamento de esterilização de solo. Colocaram-se seis sementes por vaso. Quatorze dias após a semeadura, quando as plantas já apresentavam sintomas de deficiência de ferro, fez-se a aplicação, em cada vaso, de $10 \mathrm{ml}$ de meio $B$ líquido em que as bactérias cresciam há $72 \mathrm{~h}$. Houve 29 tratamentos de inoculação, sendo uma testemunha não-inoculada e 28 inoculações com os seguintes isolados: Ps-21-A, 21-B, 21-C, 22-A, 22-B, $23-A, \quad 23-B, \quad 23-C, \quad 31-A, \quad 31-B, 31-C, 31-D, 32,33,34-A$, $34-\mathrm{B}, 34-\mathrm{C}, 41-\mathrm{A}, 41-\mathrm{B}, 41-\mathrm{C}, 42-\mathrm{A}, 42-\mathrm{B}, 42-\mathrm{C}, 43-\mathrm{A}, 43-\mathrm{B}$, 43-C, 44-A, e 44-B. Havia quatro repetições de cada tratamento. No mesmo dia fez-se a avaliação visual da deficiência de ferro de acordo com o método proposto por CIANZIO et al. (1979), em que são dadas notas variáve is com a intensidade dos sintomas, indo de 1 , em que não há sintomas de clorose, até 5 , em que as plantas estão pequenas, com clorose acentuada, principalmente nas folhas mais jovens, e com manchas necróticas no limbo foliar. Foram sempre duas pessoas a fazer essa avaliação, na mais

${ }^{1}$ MIRANDA, M.A.C. (Instituto Agronômico, Campinas) Comunicação pessoal, 1993. 
jovem folha trifoliada completa. sendo feita a média dessas observações, em que, quando houve discordância, esta não foi superior a um ponto.

Uma semana depois fez-se nova inoculação e nova avaliação, de maneira semelhante à já descrita. Outra semana ainda, esses procedimentos foram repetidos e fez-se a colheita três dias depois, consistindo esta na retirada apenas da parte aérea, que teve sua massa seca avaliada.

\subsubsection{Cu1tivar $\mathrm{T}-203$}

Neste experimento usou-se uma cultivar conhecida por ser.bastante suscetivel à clorose induzida por calcário. O experimento foi instalado da mesma maneira que o com a cultivar Santa Rosa Clorose. Nesse caso, foram t ambém feitas três inoculações só que a primeira delas foi feita uma semana após a semeadura, quando as plantas ainda não apresentavam sintomas de deficiência de ferro. A segunda inoculação foi feita uma semana depois da primeira, data em que também foi feita a primeira avaliação por notas dos sintomas de deficiência de ferro. Igualmente, a terceira inoculação, uma semana após a segunda, coincidiu com a segunda avaliação por notas. Finalmente, a terceira e última avaliação, uma semana depois da segunda, coincidiu com a colheita, que consistiu na retirada apenas da parte aérea das plantas, para pesagem de sua matéria seca. 
3.7. Testes de antagonismo

Para verificar possiveis antagonismos entre as bactérias usadas neste trabalho e fitopatógenos de solo, realizaram-se testes de confrontação de microrganismos dois a dois em placas de Petri.

Testaram-se todos os 62 isolados bacterianos listados na Tabela 1 contra os isolados de fungos, fitopatogênicos ou não, apresentados na Tabela 2 e fornecidos pela Seção de Fitopatologia do Instituto Agronômico.

Discos de meio de cultura de $4 \mathrm{~mm}$ de diâmetro contendo parte de colônia fúngica foram transferidos para o centro de placas de Petri com o meio B. A cerca de 2 cm do centro desses discos, em quatro pontos eqüidistantes, tocou-se o meio de cultura com alça de platina contendo o isolado bacteriano em teste. Prepararam-se duas placas de cada combinação, que foram mantidas a $28^{\circ} \mathrm{C}$ por tempos variáveis, de acordo com a velocidade de crescimento do fungo. A avaliação foi feita quando a borda da colônia fúngica, pelo menos nas zonas distantes da influência bacteriana, ultrapassava a colônia da bactéria. Na avaliação considerou-se apenas a presença ou não de halo de inibição da colônia fúngica em torno da colônia bacteriana . 
Tabela 2. Origem dos fungos utilizados

\begin{tabular}{|c|c|c|}
\hline Isolado & Espécie ou gênero & Origem \\
\hline $\begin{array}{ll}1505, & 2648 \\
2658, & 2908\end{array}$ & $\begin{array}{l}\text { Fusarium oxysporum f. } \\
\text { sp. lycopersici }\end{array}$ & Tomateiro \\
\hline $7083,7086-B$ & sclerotium rolfsii & Soja \\
\hline FG I AC $-8-1$ & Penicillium sp. & $\begin{array}{l}\text { Rizosfera de } \\
\text { soja }\end{array}$ \\
\hline FG I AC $-8-2$ & Não-ident if icado & $\begin{array}{l}\text { Rizosfera de } \\
\text { soja }\end{array}$ \\
\hline 7088 & F. moniliforme & Mil ho \\
\hline 6689 & Colletotrichum sp. & Milho \\
\hline $6968-A$ & Pythiumsp. & Morango \\
\hline 6828 & Pythium sp. & Cacau \\
\hline 6498 & Pythium sp. & Anona sp. \\
\hline 6666 & Phomopsis phaseoli & Soja \\
\hline $3039-1, \quad 3039-8$ & $\begin{array}{l}\text { F. oxysporum f. sp. } \\
\text { vasinfectum }\end{array}$ & Al godão \\
\hline $\begin{array}{l}\mathrm{T}-1, \mathrm{~T}-7, \mathrm{~T}-8, \\
\mathrm{~T}-12, \mathrm{~T}-13, \mathrm{~T}-15, \\
\mathrm{~T}-16, \mathrm{~T}-18\end{array}$ & Fusarium sp. & A 1 godão \\
\hline
\end{tabular}

As análises de variância dos experimentos com plantas foram feitas utilizando-se o teste $F$ a as comparações das médias, o teste de Tukey ao nível de $5 \%$. 
4. RESULTADOS E DISCUSSÃo

4.1. Experimento com feijão

Na Tabela 3 estão os dados de massa seca de parte aérea e raízes de feijoeiros, nas Tabelas 4 e 5 apresentam-se, respectivamente, os seus conteúdos de nitrogênio e fósforo e na Tabela 6 , os dados de massa de nódulos e colonização radicular micorrízica. Não estão apresentados dados sobre os tratamentos de inoculação com Ps-31-C e Ps-33 porque esses isolados causaram a morte de quase todas as plantas em que foram inoculados, constituindo-se, na verdade, em patógenos.

Do exame da Tabela 3 constata-se que não houve efeito dos isolados bacterianos sobre a parte aérea das plantas, micorrizadas ou não. De maneira geral, houve efeito benéfico da inoculação do feijoeiro com $G$. etunicatum e não de $S$. heterogama, mas esse fato já havia sido demostrado por SILVEIRA \& CARDOSO (1987) e não constituía, por si só, objeto deste estudo. Ocorreu todavia interação de isolados bacterianos e micorrizas, quase sempre em favor das plantas inoculadas com $G$. etunicatum. Já quanto às raízes, dois isolados, Ps-21-A e Ps-21-B, estimularam-1hes o crescimento em ausência de 


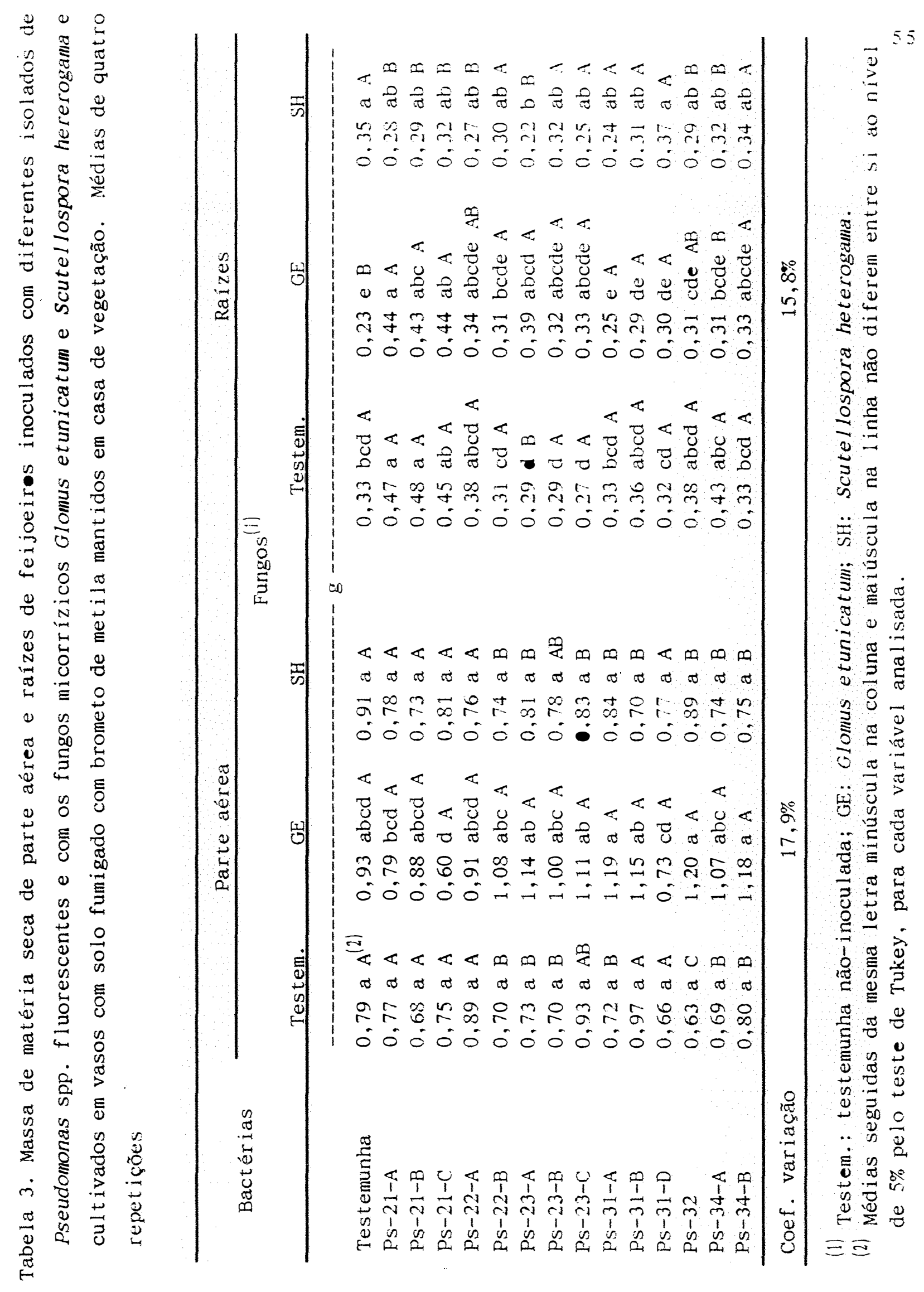




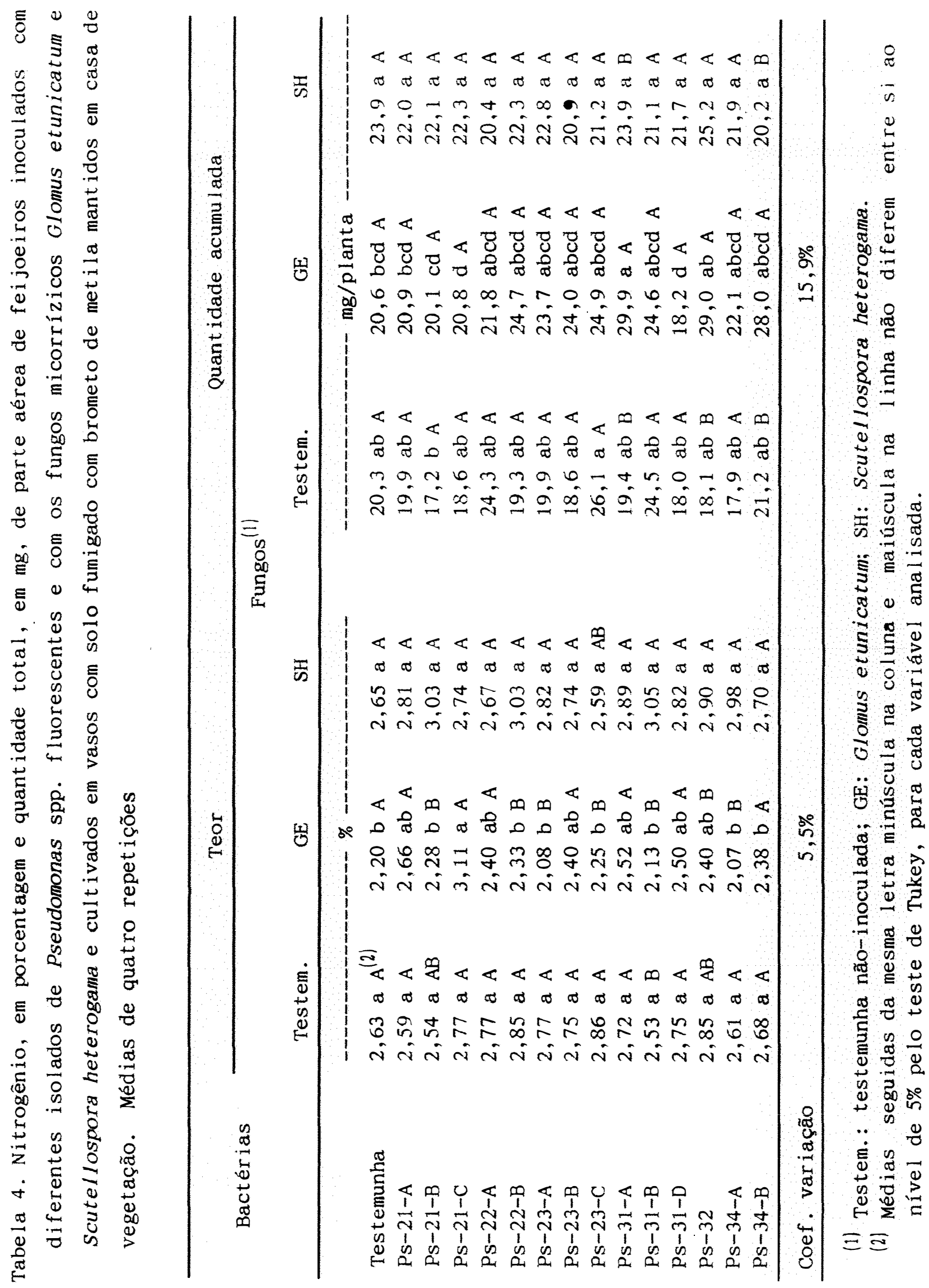



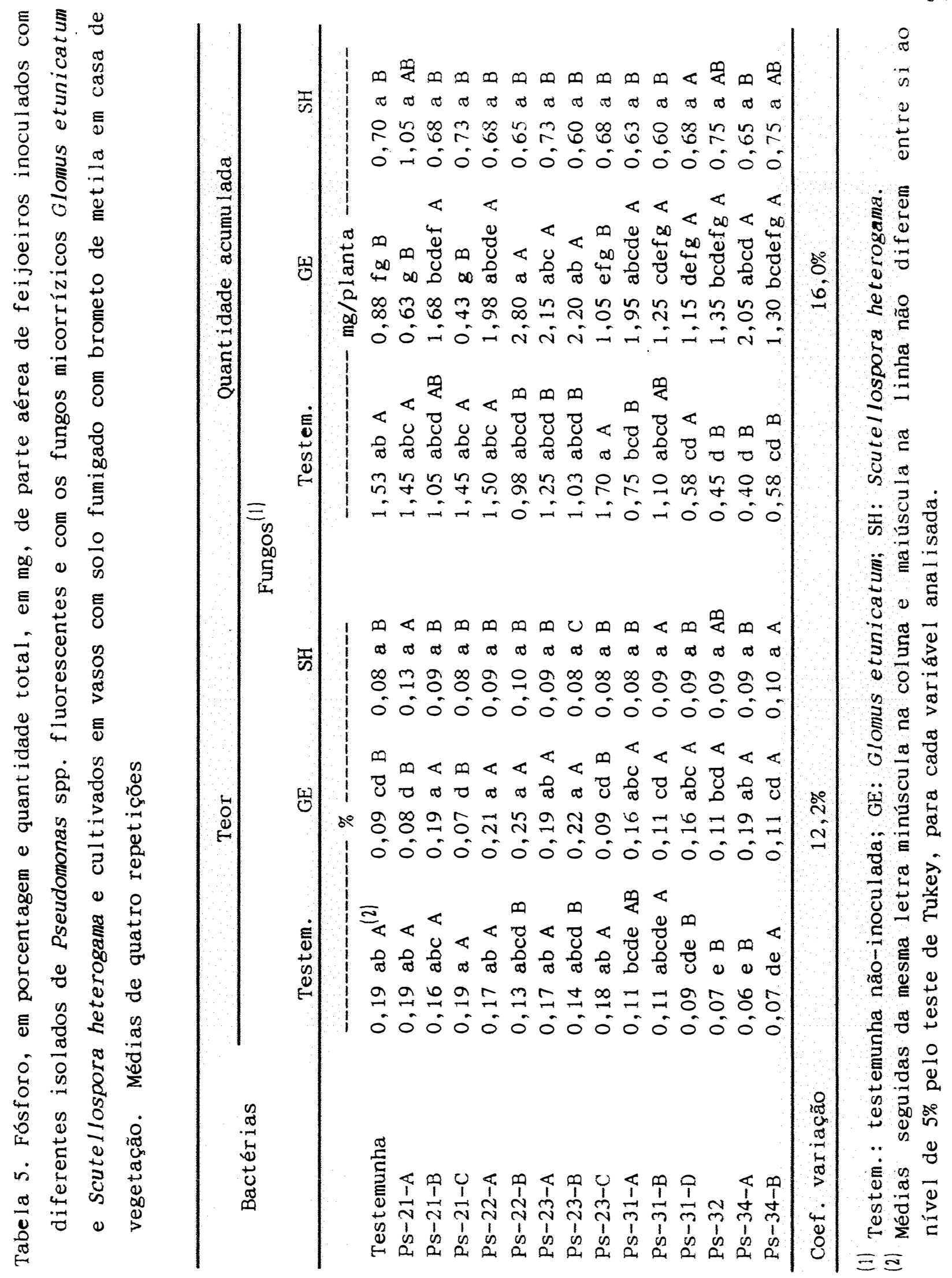


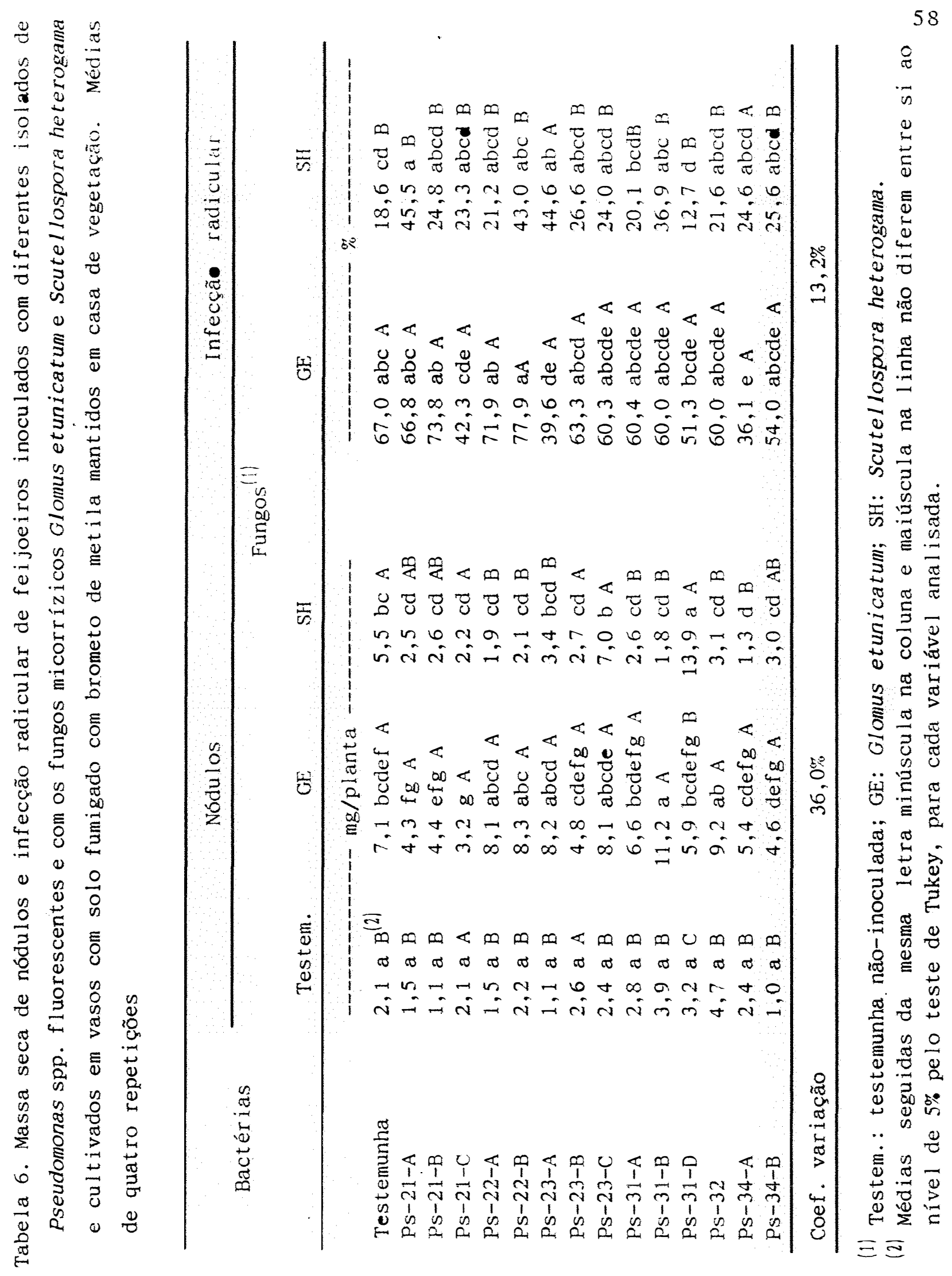


micorriza. Nas plantas inoculadas com G. etunicatum, esses mesmos isolados e também Ps-21-C e Ps-23-A favoreceramo crescimento das raízes.

Antes de se analisarem os motivos desses efeitos, é preciso considerar as outras variáveis medidas. A quantidade de nitrogênio (Tabela 4) nas plantas foi positivamente afetada pelo isolado Ps-21-C em presença de G. etunicatum, quando se considera a porcentagem de $\mathrm{N}$, e pelo isolado Ps-31-A em presença do mesmo fungo, quando se considera a quantidade total de $N$. Essas diferenças no comportamento dos isolados com respeito à forma de quantificação do $N$ são devidas provavelmente ao efeito de di lu i ção.

Como teriam esses isolados influenciado o conteúdo de nitrogênio nas plantas de feijão? Na Tabela 6 observa-se que justamente o isolado Ps-21-C resultou em menor massa de nódulos em relação à testemunhä, em presença de G. etunicatum. Aventa-se a hipótese de Pseudomonas e Glomus em conjunto terem aumentado a eficiência da fixação dos Rhizobia inoculados, ainda que se desconheça, aqui, a forma pela qual esse efeito seria conseguido. O mesmo não é verdade para os isolados Ps-31-B, em presença de Glomus, e Ps-31-D, com Scutellospora, que, embora propiciando maiores massas nodulares, não resultaram em maiores teores de N. O inverso também foi verdadeiro: o isolado Ps-34-A diminuiu a massa nodular em relação à testemunha nãoinoculada, em presença de scutellospora, sem que isso 
resultasse em prejuízo de qualquer outra variável analisada. Esse fenômeno pode gerar semelhanças com o ocorrido com Ps-21-C, já discutido, uma vez que, aqui, a menor massa nodular também não resultou na diminuiça da aquisição de nitrogênio, o que poderia indicar indiretamente uma maior eficiência.

Nesse caso, o efeito dos isolados Ps-31-B e Ps-31-D, acima comentados, poderia ser de prejuízo sobre a eficiência de aquisição de $\mathbf{N}$ pelas plantas.

$\mathrm{Na}$ Tabela 5 observam-se vários efeitos de isolados bacterianos sobre o conteúdo de fósforo das plantas, interagindo de diferentes formas com as micorrizas.

Os isolados Ps-31-D, 32, 34-A e 34-B afetaram negativamente o conterido de fósforo das plantas não-micorrizadas mas, em presença de Glomus etunicatum, Ps-34A aumentou esse conteúdo, quando comparado com as plantas sem inoculação de bactérias. Em presença do mesmo fungo, outros cinco isolados também favoreceram a aquisição de fósforo pelas plantas. Assim, a inoculação com Glomus, por si só, anulou o efeito deletério daqueles quatro isolados sobre a quantidade de fósforo nas plantas e favoreceu a manifestação benéfica de outros cinco isolados sobre essa mesma variável.

O exame dos teores de fósforo das testemunhas não-inoculadas com bactérias revela que, surpreendentemente, contrariando SILVEIRA \& CARDOSO (1987), 
essas variáeis foram prejudicadas pela inoculação com os fungos micorrízicos, fato cuja explicação não é objeto deste trabalho. Para o fósforo, assim como para as outras variáveis analisadas, houve um efeito benéfico da inoculação conjunta de bactérias com G. etunicatum.

Ocorreram variadas interaçōes das micorrizas com as bactérias. Voltando à Tabela 6, os isolados Ps-23-A e 34-A diminuíram a infecção radicular por Glomus. Isto traz à baila o trabalho de PAULITZ \& LINDERMAN (1989), em que se observou que as populaçōes de $P$. putida e $P$. fluorescens diminuiram na micorrizosfera de $G$. intraradices. Os autores consideraram que isso se deveu ao fato de o primeiro fungo ser colonizador rápido, competindo com as bactérias por exsudatos radiculares. Assim, seria razoável pensar-se que, por ser um colonizador mais lento, G. etunicatum pode ter competido com desvantagem com as bactérias inoculadas, que teriam desfavorecido o seu estabelecimento na rizosfera e, por conseguinte, a colonização radicular.

Já os isolados Ps-21-A e 23-A favoreceram a colonização radicular por $s$. heterogama. Nota-se aqui um comportamento interessante do isolado Ps-23-A, favorecendo a colonização radicular por $S$. heterogama e desfavorecendo- a por G. etunicatum. Isto revela especificidade entre bactéria e fungo, o que não é de surpreender quando se considera o ambiente da rizosfera.

Ainda que os vários efeitos das bactérias 
sobre a nutrição do feijoeiro não se tenham traduzido em desenvolvimento da parte aérea (mas das raízes sim\}, é preciso levar em conta que neste experimento interagiram pelo menos quatro organismos: planta, fungo micorrízico, bactéria fluorescente e bactéria fixadora de nitrogênio. E natural, pois, que interações complexas ocorram, como as demonstradas aqui.

\subsection{Experimento com milho}

os dados de matéria seca de parte aérea e raízes de milho são apresentados na Tabela 7 .

Note-se que alguns tratamentos de inoculação não estão lá apresentados, os de inoculação com os isolados Ps-23-B, 31-D, 33, 34-A, 34-C, 41-B, 42-A, 42-C, 52-A, 52B, 53-B, 54-B, 54-C, 136RN e W4F58. Cumpre" notar que BRANDÃO (1989) observou que o isolado $136 R$ antecipou a emergência de plântulas de milho semeado em solo natural, sugerindo que esse efeito poderia ter sido ocasionado por antagonismo a uma microbiota deletéria, já que não ocorreu em solo esterilizado. No tratamento com Ps-42-C morreram as plantas cultivadas em solo esterilizado e nos outros, as cultivadas em solo natural. Por isso, esses tratamentos foram excluídos da análise estatística.

No caso do isolado Ps-42-C, pode-se deduzir que a bactéria resultou ser patogênica ao milho, exercendo plenamente sua ação quando inoculada em condições 
vantajosas, em solo esterilizado; no solo natural, pela presença da microbiota nativa, o estabelecimento elou a atividade da bactéria foram inibidos, explicando a sobrevivência das plantas nessas condiços.

Já o ocorrido com os outros quatorze isolados tem explicações mais complexas. Se estes também fossem patogênicos, à semelhança do Ps-42-C, é crível que a morte das plantas ocorresse no solo esterilizado, onde a patogenicidade teria mais condições de se evidenciar, e não no natural, onde haveria competição com a microbiota nativa. Nota-se, pelo exame da Tabela ?: que a parte aérea das plantas inoculadas e mantidas em solo natural e as raízes das inoculadas, nas duas condições de esterilização de solo, não diferiram significativamente das testemunhas respectivas. Apenas, a parte aérea do tratamento de inoculação com Ps-21-A foi significativamente menor que a testemunha em. solo esterilizado e também que seu correspondente em solo natural. Esse isolado teve comportamento patogênico semelhante ao Ps-42-C, ainda que não tão drástico.

Dado o grande número de tratamentos em que ocorreu morte no solo natural, poder-se-ia pensar na situação inversa: a ocorrência generalizada de um patógeno qualquer entre os microrganismos nativos cuja manifestação teria ocorrido em presença dos sobreditos quatorze isolados mas não com os outros 31 que se apresentam na Tabela 7 . Ainda que desejável, essa hi pótese é prontamente descartada 
quando se constata que não houve diferença causada pela esterilização do solo nas testemunhas não-inoculadas. Além disso, a comparaçào das médias pelo teste de Tukey, apenas para os dois tratamentos de esterilização do solo. indicou que a parte aérea das plantas teve seu desenvolvimento significativamente maior no solo natural, o que seria de ocorrência pouco provável se no solo estivesse agindo um patógeno que levasse as plantas à morte, ainda que inibido pela inoculação das bactêrias.

O exame da tabela revela ainda comportamento diferente de treze isolados (Ps-21-A, 22-B, 31-B, 31-C, 32, $41-C, 43-A, 43-C, 44-A, 51-B, 53-A, W+F 35$ e $W+P 144)$ em solo esterilizado e natural, quando se considera a parte aérea. Para as raízes, apenas très isolados tiveram essa interaçào com o solo: Ps-21-A, 32 e W4P5. Na maioria dos casos, a variável analisada, parte aérea ou raízes, teve menor desenvolvimento no solo esterilizado. Isso dá a idéia de que um possível efeito prejudicial do isolado sobre a planta teria sido anulado pela microbiota nativa.

As exceções a esse comportamento ficaram por conta do isolado Ps-53-A, na parte aérea, e \#4P5, nas raízes, que resultaram em melhor desenvolvimento das respectivas variáveis no solo esterilizado em relação ao natural. Esses isolados, aliás, a inda que não diferentes das respectivas testemunhas, foram os que propiciaram os mais altos valores de massa nas variáveis mencionadas. Tudo nesse comportamento leva a supor que os dois isolados 
poderiam exercer efeito benéfico sobre plantas de milho, podendo-se recomendar estudos mais detalhados com ambos. Aliás, W4P5 foi um dos isolados que BRANDÃO (1989) identificou como benéficos a plantas de milho.

Todavia, o melhor comportamento, em geral. das plantas no solo natural, possivelmente determinado pelos isolados acima discriminados (doze para a parte aérea e dois para as raízes), pode ser creditado, mais razoavelmente, a uma tendência das bactérias em prejudicar mais do que favorecer o crescimento das plantas.

Se for realmente admitida essa teñdência, qual seria sua causa? Lembre-se que milho é uma das plantas com a estratégia I de obtenção de ferro do substrato, a Iiberação de fitossideróforos. No solo dos vasos, com valor de pH em $\mathrm{CaCl}_{2}$ de 6,3, o ferro não deveria estar disponivel para as plantas, o que ativaria a liberação de fitossideróforos, caso a planta fosse eficiente em ferto. Ainda que RöMHELD \& MARSCHNER (1986) tenham considerado que a estratégia II teria sobre a I a vantagem de não ser inibida por valores altos de pH, BARNESS et al. (1992) verificaram que fitossideróforos podem ser degradados por microrganismos rizosféricos. É o que pode ter acontecido aqui: em deficiência de ferro, as plantas teriam excretado fitossideróforos que teriam sido decompostos pelas bactérias inoculadas. Contra isso pode-se argumentar que essa decomposição teria sido mais ativa 
Tabela - Massa de matéria seca da parte aérea e raízes de plantas de milho inoculadas com diferentes isolados de Pseudomonas spp. fluorescentes e cultivadas em vasos com solo esterilizado ou natural mantidos em casa de vegetação. Médias de quatro repetições.

\begin{tabular}{|c|c|c|c|c|}
\hline \multirow[b]{3}{*}{ Bactérias } & \multicolumn{2}{|c|}{ Parte aérea } & \multicolumn{2}{|c|}{ Raizes } \\
\hline & \multicolumn{4}{|c|}{ Solos } \\
\hline & Esterilizado & Natural & Esterilizado & Natural \\
\hline & \multicolumn{4}{|c|}{ 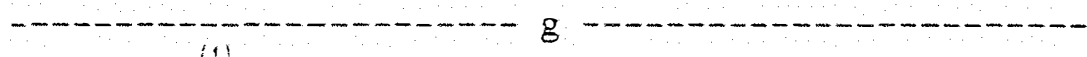 } \\
\hline Testemunha & $1,65 \mathrm{ab} \mathrm{A}^{11}$ & $1.49 \mathrm{ab} \mathrm{A}$ & $1,13 \mathrm{ab} A$ & 1,47 a $A$ \\
\hline Ps $-21-\mathrm{A}$ & $0.65 \mathrm{cB}$ & $1.53 \mathrm{ab} \mathrm{A}$ & $0,51 \mathrm{~b} B$ & 1.81 a $\mathrm{A}$ \\
\hline Ps $-21-B$ & $1,80 \mathrm{ab} \mathrm{A}$ & $1.73 \mathrm{ab} \mathrm{A}$ & $1.39 \mathrm{ab} . \mathrm{A}$ & 1,44 a $A$ \\
\hline PS $-21-C$ & $1,6^{-} \mathrm{ab} \mathrm{A}$ & $1,72 \mathrm{ab} A$ & 2,49 a $A$ & $1,-3$ a $\mathrm{A}$ \\
\hline$P s-22-A$ & $1.75 \mathrm{ab} \mathrm{A}$ & $1.64 \mathrm{ab} A$ & $1.58 \mathrm{ab} A$ & $1.5 \mathrm{~S}$ a $\mathrm{A}$ \\
\hline PS $-22-B$ & $1.35 \mathrm{abc} B$ & 2.01 a A & $1,2^{-} a b A$ & 1.49 a A \\
\hline PS-23-A & $1.50 \mathrm{ab} \mathrm{A}$ & 1,51 ab $A$ & $1,34 \mathrm{ab} A$ & 1.75 a $\mathrm{A}$ \\
\hline$P s-23-C$ & $1,33 \mathrm{abc} \mathrm{A}$ & $1.43 \mathrm{ab} \mathrm{A}$ & 0,96 ab $A$ & $1.6^{-}$a A \\
\hline Ps-31-A & $1.55 \mathrm{ab} A$ & 1. $-0 a b A$ & $1,11 \mathrm{ab} A$ & 1,7 a $\mathrm{A}$ \\
\hline$P S-31-B$ & $1,22 a b c B$ & $1,3^{-} \mathrm{ab} \mathrm{A}$ & $1,90 \mathrm{ab} A$ & 1,45 a $\mathrm{A}$ \\
\hline Ps $-31-C$ & 1,04 bc $\mathrm{B}$ & $1,75 \mathrm{ab} A$ & $1,12 \mathrm{ab} A$ & $1,83 \mathrm{a} \mathrm{A}$ \\
\hline Ps -32 & $1,24 \cdot a b c B$ & $1.89 \mathrm{ab} \mathrm{A}$ & 1,11 ab $B$ & 2,09 a $\mathrm{A}$ \\
\hline Ps $-34-B$ & $1,54 \mathrm{ab} A$ & $1,-2 a b A$ & $1.7-$ ab $A$ & 1,84 a $\mathrm{A}$ \\
\hline$P S-41-A$ & $1,21 \mathrm{abc} A$ & $1,+4 \mathrm{ab} A$ & 1,46 ab $A$ & $1,10 \mathrm{aA}$ \\
\hline Ps $-41-C$ & 1.20 abc $B$ & $1 . S 2 \mathrm{ab} A$ & $1.19 \mathrm{ab} \mathrm{A}$ & $1 .-0$ a $\mathrm{A}$ \\
\hline$P s-42-B$ & $1,49 \mathrm{ab} \mathrm{A}$ & $1,87 \mathrm{ab} A$ & 2,01 ab $A$ & $1,83 \mathrm{a} \mathrm{A}$ \\
\hline$P s-43-A$ & 1,32 abc $B$ & $1.95 \mathrm{ab} \mathrm{A}$ & $1,6+\mathrm{ab} \mathrm{A}$ & 2.02 a $\mathrm{A}$ \\
\hline$P s-43-B$ & 1,43 abc $A$ & $1 . S 4 a b A$ & 1,84 ab $A$ & 1,86 a $\mathrm{A}$ \\
\hline Ps $-43-C$ & $1,26 \mathrm{abc} B$ & $1.87 \mathrm{ab} A$ & 1,53 ab $A$ & $1,53 \mathrm{a} \mathrm{A}$ \\
\hline PS $-44-A$ & 1,37 abc $B$ & $1,91 \mathrm{ab} \mathrm{A}$ & 1.21 ab $A$ & 1,70 a $\mathrm{A}$ \\
\hline Ps $-44-B$ & $1,38 \mathrm{abc} A$ & $1,65 \mathrm{ab} A$ & 1,28 ab $A$ & 1,44 a $A$ \\
\hline Ps $-51-A$ & 1,47 abc $A$ & $1,89 a b A$ & 2,25 a $\mathrm{A}$ & $1,4 ?$ a $\mathrm{A}$ \\
\hline Ps $-51-B$ & $1,24 \mathrm{abc} B$ & 1,71 ab $\mathrm{A}$ & 0,98 ab $\mathrm{A}$ & 1,17 a $\mathrm{A}$ \\
\hline Ps-53-A & 1,89 a $\mathrm{A}$ & $1,36 \mathrm{ab} B$ & $1,60 \mathrm{ab} \mathrm{A}$ & 1.07 a $\mathrm{A}$ \\
\hline Ps $-53-C$ & $1 ; 44$ abc $A$ & $1,47 \mathrm{ab} A$ & $1,87 \mathrm{ab} A$ & 1,45 a $A$ \\
\hline Ps $-54-A$ & 1,44 abc $\mathrm{A}$ & 1,13 b A & $1,96 \mathrm{ab} A$ & $1,23 \mathrm{a} \mathrm{A}$ \\
\hline $620-18$ & 1,39 abc $\mathrm{A}$ & $1,62 \mathrm{ab} A$ & $1,13 \mathrm{ab} A$ & 1,46 a $\mathrm{A}$ \\
\hline W4F35 & 1,18 abc $B$ & 2,19 a $\mathrm{A}$ & 1,62 ab $A$ & $1.55 \mathrm{a} \mathrm{A}$ \\
\hline W4F 111 & $1,76 \mathrm{ab} A$ & $1,60 \mathrm{ab} \mathrm{A}$ & $0,9^{7}$ ab A & 1,17 a $\mathrm{A}$ \\
\hline W4F 164 & 1,24 abc $A$ & $1,66 \mathrm{ab} A$ & $1,80 \mathrm{ab} A$ & 1,19 a $\mathrm{A}$ \\
\hline W4P5 & 1,57 abc $A$ & $1, S 2 a b A$ & 2,43 a $\mathrm{A}$ & 1,40 a $B$ \\
\hline W4P144 & $1,40 \mathrm{ab} \mathrm{B}$ & 1,92 ab $A$ & 1,80 ab $A$ & 1,78 a $\mathrm{A}$ \\
\hline Coef. variação & \multicolumn{2}{|c|}{$20,0 \%$} & \multicolumn{2}{|c|}{$39,1 \%$} \\
\hline
\end{tabular}

Médias seguidas da mesma letra minúscula na coluna e maiúscula na linha não diferem entre si ao nível de $5 \%$ pelo teste de Tukey, para cada variável analisada. 
no solo natural, com microbiota mais variada. Mas e se essa decomposição fosse propiciada justamente por uma população tão especializada que desenvolveu a produção de compostos específicos para a quelação do ferro? Uma população como essa é que seria favorecida pela decomposição dos fitossideróforos. Além disso é bom lembrar que sideróforos microbianos são mais específicos que fitossideróforos (TREEBY et al., 1989), o que conferiria vantagem aos organismos produtores dos primeiros.

Não se observaram sintomas de deficiência de ferro nas plantas de milho, é bom que se ressalte, mas COsTA \& SOUZA (1976) já assinalaram que existe a possibilidade de o ferro ocorrer em quantidades marginais em determinadas condições, causando reduçōes nãoreconhecidas na produção.

Voltando ao problema proposto no início deste item, permanece sem explicação a morte de plantas em solo natural quando inoculadas com quatorze isolados de Pseudomonas spp. Pode-se pensar que tais isolados teriam, de maneira desconhecida, favorecido a atividade de outros microrganismos no solo natural, de tal maneira que, em interação sinérgica com as bactérias inoculadas, tais patógenos potenciais tenham podido se manifestar, matando as plantas.

Ainda que as condições do experimento não permitam a prova dessas explicações apresentadas, ressalte- 
-se que estão todas alicerçadas pela literatura já discutida e poderiam perfeitamente ter ocorrido nas condições prevalentes.

4.3. Experimento com tomateiro

Os dados de massa de matéria seca de parte aérea e raízes de tomateiro estão apresentados na Tabela 8. Analisando-se os dados de parte aérea das plantas cultivadas em solo natural e de raizes tanto em solo esterilizado quanto natural observa-se que nenhum dos tratamentos de inoculação com bactérias diferiu das testemunhas não-inoculadas. Mas a massa de parte aérea das plantas inoculadas com os isolados $136 \mathrm{RN}$ e MSC foi significativamente menor que a da testemunha näo-inoculada, em solo esterilizado. Novamente, o isolado 136RN teve efeito oposto ao observado por BRANDÃO (1989), que relatou benefícios pela sua inoculação em milho.

Aqui, à semelhança do que ocorreu com milho, verificou-se que Pseudomonas spp. fluorescentes podem afetar negativamente o desenvolvimento de tomateiros, ainda que em milho o isolado prejudicial tenha sido outro $(P s-21-A)$.

A análise geral apenas dos tratamentos de esterilização de solo indicou que as plantas cultivadas em solo natural apresentaram massas de parte aérea significativamente maiores que as cultivadas em solo 
esterilizado. Essa constat ação, aliada ao fato de que na testemunha isso não ocorreu, mas sim com treze isolados bacterianos, leva mais uma vez à conclusão de que as bactérias inoculadas agiram no sentido de diminuir o desenvolvimento das plantas de tomate. Quando submetidas ao confronto com a microbiota natural as bactérias tiveram sua ação inibida. Poucos desses isolados (Ps-21-A, Ps31-B, Ps-53-A e 136RN) agiram da mesma forma quando inoculados em milho. Um deles: 136RN, matou as plantas de milho em que foi inoculado e aqui também prejudicou os tomateiros, mas, de maneira geral, os isolados tiveram comportamento diferente nas duas espécies vegetais. Não se detecta qualquer relação entre a origem do isolado e a sua atuação numa ou noutra espécie vegetal. Essa aparente falta de especificidade torna os resultados tanto mais interessantes quanto se sabe que a comunidade de Pseudomonas fluorescentes é muito grande na rizosfera de tomateiro (FREITAS, observação pessoal). Neste caso, visto não ser o tomateiro planta que tenha a estratégia I para obtenção de ferro, não há que se invocar a competição entre fitossideróforos e sideróforos microbianos como explicação para o efeito deletério de Pseudomonas spp. Pode-se considerar que os isolados fluorescentes inoculados tiveram efeito típico de patógeno subclínico, principalmente o $136 R N$, uma vez que não foram observados sintomas clássicos de doença nas plantas, como murcha, clorose ou necrose, apenas essa diminuição no crescimento detectada pela 
Tabela 8. Massa de matéria seca de parte aérea e raízes de tomateiros cultivar Santa clara inoculados com diferentes isolados de Pseudomonas spp. fluorescentes e cultivados em vasos com solo esterilizado ou natural mantidos em casa de vegetação. Médias de quatro repetições.

\begin{tabular}{|c|c|c|c|c|}
\hline \multirow{3}{*}{ Bactérias } & \multicolumn{2}{|c|}{ Parte aérea } & \multicolumn{2}{|c|}{ Raízes } \\
\hline & \multicolumn{4}{|c|}{ So 10} \\
\hline & Esterilizado & Natural & Esterilizado & Natural \\
\hline Testemunha & 3,08 a $A^{(1)}$ & 3,06 a $\mathrm{A}$ & $0,48 \mathrm{ab} A$ & 0,38 ab $\mathrm{A}$ \\
\hline Ps-21-A & $1,97 a b c B$ & 3,21 a $\mathrm{A}$ & 0,29 ab $\mathrm{A}$ & $0,35 \mathrm{ab} A$ \\
\hline Ps $-21-B$ & $1,61 \mathrm{abc} B$ & 2,93 a $\mathrm{A}$ & $0,30 \mathrm{ab} A$ & $0,35 \mathrm{ab} \mathrm{A}$ \\
\hline Ps $-21-C$ & 1,31 abc $B$ & 2,47 a $A$ & 0,27 ab $\mathrm{A}$ & $0,26 \mathrm{ab} A$ \\
\hline$P s-22-A$ & 1,34 abc $B$ & 3,04 a $\mathrm{A}$ & 0,18 ab $\mathrm{A}$ & 0,35 ab $\mathrm{A}$ \\
\hline Ps $-22-B$ & 2,41 abc $A$ & 3,17 a $\mathrm{A}$ & $0,35 \mathrm{ab} A$ & 0,51 ab $\mathrm{A}$ \\
\hline Ps $-23-A$ & $1,53 \mathrm{abc} A$ & 2,33 a $\mathrm{A}$ & $0,24 \mathrm{ab} A$ & $0,22 \mathrm{ab} A$ \\
\hline Ps $-23-B$ & $2,98 \mathrm{ab} A$ & 2,75 a $\mathrm{A}$ & 0,49 ab $\mathrm{A}$ & 0,30 ab $\mathrm{A}$ \\
\hline Ps $-23-C$ & 2,70 abc $A$ & 2,91 a $\mathrm{A}$ & $0,37 \mathrm{ab} A$ & $0,34 \mathrm{ab} \mathrm{A}$ \\
\hline Ps $-31-A$ & $1,32 \mathrm{abc} B$ & 2,59 a $A$ & $0,53 \mathrm{ab} A$ & $0,44 \mathrm{ab} A$ \\
\hline Ps-31-B & 1,17 abc $B$ & 3,18 a $A$ & $0,30 \mathrm{ab} A$ & 0,48 ab $\mathrm{A}$ \\
\hline Ps $-31-C$ & 2,89 abc $A$ & 2,87 a $\mathrm{A}$ & $0,40 \mathrm{ab} A$ & $0,31 \mathrm{ab} A$ \\
\hline Ps $-31-D$ & $2,49 a b c A$ & 2,29 a $\mathrm{A}$ & 0,40 ab $A$ & $0,31 \mathrm{ab} A$ \\
\hline Ps -32 & $2,02 a b c A$ & 2,57 a $A$ & $0,35 \mathrm{ab} A$ & $0,34 \mathrm{ab} \mathrm{A}$ \\
\hline Ps -33 & $2,60 a b c A$ & 2,55 a $\mathrm{A}$ & $0,34 \mathrm{ab} \mathrm{A}$ & $0,44 \mathrm{ab} \mathrm{A}$ \\
\hline PS-34-A & $2,53 \mathrm{abc} A$ & 2,61 a $A$ & $0,39 a b A$ & 0,43 ab $\mathrm{A}$ \\
\hline Ps-34-B & 2,68 abc $A$ & 3,03 a $\mathrm{A}$ & $0,37 \mathrm{ab} A$ & $0,35 \mathrm{ab} \mathrm{A}$ \\
\hline Ps $-34-C$ & $2,93 \mathrm{abc} A$ & 2,64 a $A$ & $0,40 a b \mathrm{~A}$ & $0,30 \mathrm{ab} A$ \\
\hline Ps $-41-A$ & $2,37 \mathrm{abc} A$ & 3,02 a $\mathrm{A}$ & 0,31 ab $\mathrm{A}$ & $0,40 \mathrm{ab} A$ \\
\hline Ps $-41-B$ & 2,82 abc $A$ & 3,43 a $\mathrm{A}$ & $0,33 \mathrm{ab} \mathrm{A}$ & $0,44 a b$ A \\
\hline Ps $-41-C$ & 2,09 abc $A$ & 2,93 a $A$ & $0,24 \mathrm{ab} A$ & $0,34 \mathrm{ab} A$ \\
\hline Ps-42-A & $2,78 \mathrm{abc} A$ & 3,03 a $\mathrm{A}$ & $0,40 \mathrm{ab} A$ & $0,41 a b \mathrm{~A}$ \\
\hline Ps-42-B & 1,39 abc $B$ & 2,88 a $\mathrm{A}$ & $0,27 \mathrm{ab} A$ & $0,30 \mathrm{ab} A$ \\
\hline Ps $-42-C$ & $2,26 a b c A$ & 3,06 a $\mathrm{A}$ & $0,31 \mathrm{ab} A$ & $0,44 \mathrm{ab} A$ \\
\hline Ps $-43-A$ & 2,29 abc $A$ & 2,38 a $A$ & $0,41 a b A$ & 0,26 ab $A$ \\
\hline Ps $-43-B$ & 2,84 abc $A$ & 3,14 a $A$ & $0,46 \mathrm{ab} A$ & $0,42 \mathrm{ab} A$ \\
\hline Ps $-43-C$ & 2,76 abc A & 2,44 a $\mathrm{A}$ & $0,43 \mathrm{ab} A$ & $0,26 \mathrm{ab} A$ \\
\hline Ps-44-A & 1,75 abc $A$ & 2,68 a $A$ & $0,22 a b A$ & $0,37 \mathrm{ab} A$ \\
\hline Ps-44-B & 2,96 abc A & 2,59 a $\mathrm{A}$ & $0,48 \mathrm{ab} \mathrm{A}$ & $0,32 \mathrm{ab} A$ \\
\hline Ps $-51-A$ & $2,11 a b c A$ & 2,54 a $\mathrm{A}$ & $0,28 \mathrm{ab} \mathrm{A}$ & $0,36 \mathrm{ab} \mathrm{A}$ \\
\hline Ps $-51-B$ & 2,48 abc $A$ & 2,56 a $\mathrm{A}$ & $0,31 \mathrm{ab} A$ & $0,45 \mathrm{ab} \mathrm{A}$ \\
\hline Ps $-52-A$ & $2,20 \mathrm{abc} A$ & 2,46 a $A$ & 0,41 ab $\mathrm{A}$ & $0,34 \mathrm{ab} A$ \\
\hline Ps-52-B & 2,22 abc $A$ & 2,41 a $A$ & $0,35 a b A$ & $0,40 \mathrm{ab} A$ \\
\hline Ps-53-A & $1,91 \mathrm{abc} B$ & 3,09 a $\mathrm{A}$ & $0,26 \mathrm{ab} A$ & $0,36 \mathrm{ab} \mathrm{A}$ \\
\hline Ps $-53-B$ & 2,72 abc $A$ & 2,51 a $A$ & $0,38 \mathrm{ab} \mathrm{A}$ & $0,35 \mathrm{ab} A$ \\
\hline Ps $-53-C$ & 2,04 abc B & 3,40 a $\mathrm{A}$ & 0,48 a $A$ & 0,49 a $\mathrm{A}$ \\
\hline
\end{tabular}

Cont inua... 
Tabela 3. Massa de matéria seca de parte aérea e raízes de tomateiros cultivar Santa Clara inoculados com diferentes isolados de Pseudomonas spp. fluorescentes e cultivados em vasos com solo esterilizado ou natural mantidos em casa de vegetação. Médias de quatro repetições (cont inuação).

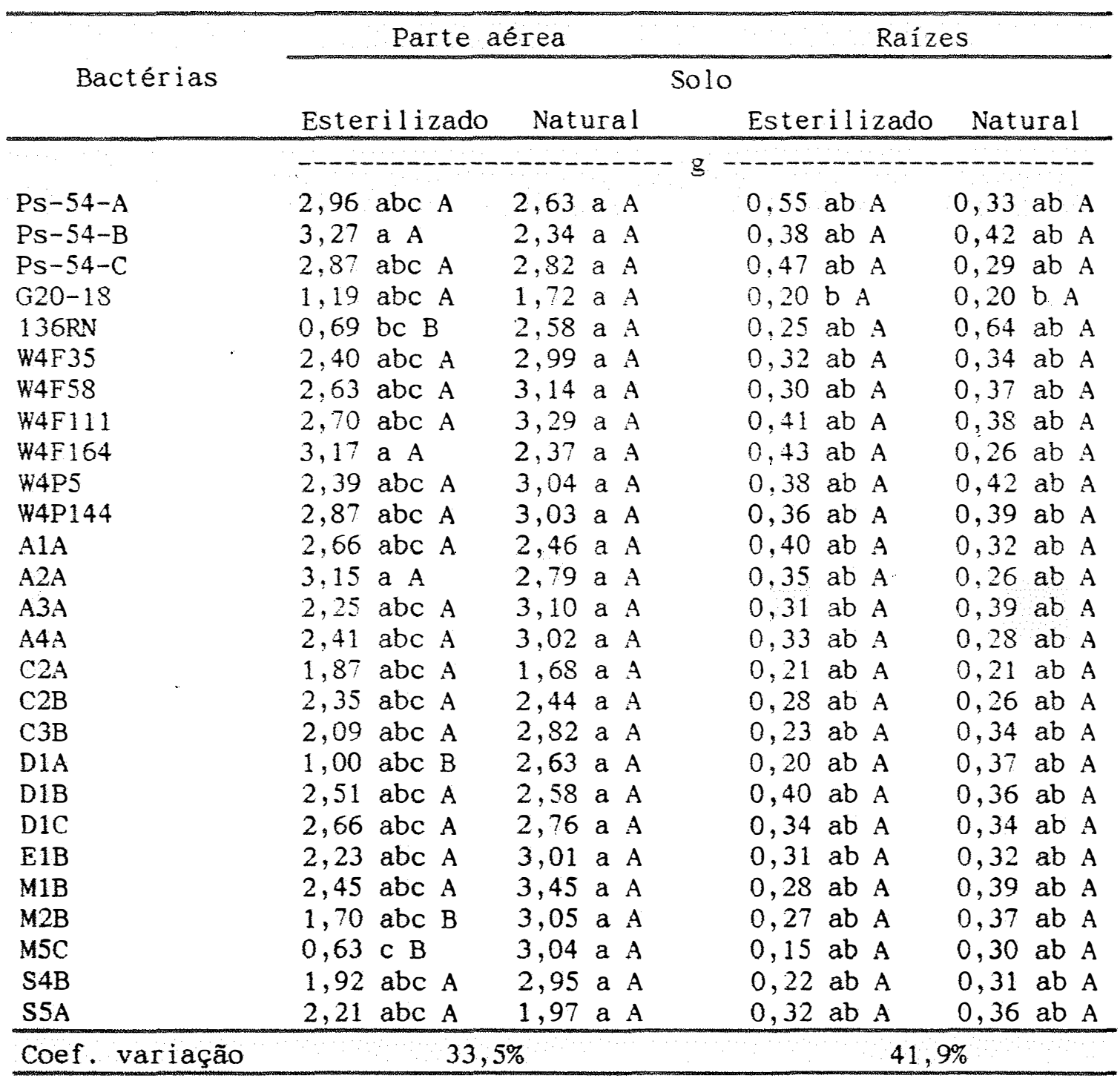

(1) Médias seguidas da mesma letra minúscula na coluna e maiúscula na linha não diferem entre si ao nível de $5 \%$ pelo teste de Tukey, para cada variável analisada. 
comparação com as testemunhas não-inoculadas. Neste trabalho, a situação é diversa da relatada por fREITAS \& PizZINATTO (1991), também para tomateiro, em que a inoculação com Pseudomonas fluorescentes resultou em benefício para as plantas: naquele caso as RPCPs agiram contra um patógeno específico, inoculado, enquanto que aqui nada se fez nesse sentido.

Quanto ao isolado M5C, de Bacillus spp., as considerações são semelhantes às feitas para o 136RN. As bactérias do gênero Bacillus são conhecidas como produtoras de antibiótico e não de sideróforos. Na Tabela 12 (item 4.5) pode-se verificar que o isolado M5C apenas apresentou antagonismo "in vitro" contra um fungo de solo. Isso dá idéia de que o M5C, ao contrário do que se espera para o Bacillus, seja fraco produtor de antibióticos, não sendo pois surpreendente a sua inatividade como RPCP. Além disso, o isolado M5C mostrou, no mínimo, atividade como patógeno subclínico.

Cumpre notar, finalmente, que essa atividade prejudicial ao crescimento das plantas apresentada pelas bactérias tanto no milho quanto em tomateiro deve ter sua manifestação limitada no campo, uma vez que a microbiota nativa exerce um efeito "tampão" no sentido de manter o equilíbrio da comunidade rizosférica. Todavia, a alteração da microbiota nativa pode facilmente resultar no favorecimento daquela atividade, ocorrendo então depressões imperceptíveis no desenvolvimento vegetal. Essa 
imperceptibilidade da depressão dar-se-ia não pela sua extensão mas pela ausência de uma planta-testemunha.

4.4. Experimentos com soja

Os dados dos experimentos realizados com as três cultivares de soja estão apresentados na Tabela" 9 (Cultivar Santa Rosa) e 10 (Cultivares Santa Rosa Clorose e $\mathrm{T}-203)$.

Da análise da Tabela 9 logo se observa que não houve qualquer efeito de inoculação das bactérias sobre o desenvolvimento da planta medido em matéria seca de parte aérea e de raízes, quer no solo esterilizado, quer no natural. Também não houve diferença no efeito de qualquer isolado num dos tratamentos de esterilização do solo em relação ao outro. Isto é bem diferente do que já aconteceu com as plantas de milho e soja, discutido anteriormente.

Quando se optou pelo uso de uma cultivar eficiente em ferro a pergunta era: estará a eficiência da cultivar ligada, pelo menos em parte, à sua capacidade de se associar a bactérias que lhe tornem o ferro disponivel? Foram dadas as condições de baixa disponibilidade de ferro, o alto valor de pH $\left(6,3\right.$ em $\left.\mathrm{CaCl}_{2}\right)$, e permitiu-se que as plantas crescessem em solo esterilizado e natural, visando a detectar um possível efeito de controle biológico de fitopatógenos. Todavia, não se detectou nenhum sintoma visual de deficiência de ferro ou de doença nem diminuição 
na produção de matéria seca, ocasionada seja por problemas nutricionais seja por problemas patológicos.

$$
\text { Quanto à patologia, a conclusão mais óbria, }
$$

uma vez que nenhum patógeno foi inoculado, é a de que nem a microbiota nativa nem as bactérias fluorescentes inoculadas se constituíram em patógenos maiores ou menores. Ha aqui uma situação diferente da que ocorreu com o mi.lho e o tomateiro.

Em termos nutricionais, especificamente quanto ao ferro, não parece ser a presença de Pseudomonas fluorescentes na rizosfera da cultivar Santa Rosa um fator decisivo na sua eficiência em ferto.

Já quanto ao comportamento das cultivares Santa Rosa Clorose e T-203, observável na Tabela 10, os resultados têm outra explicação. Como a avaliação visual da deficiência de ferro não acusou diferença estatística entre as três avaliações feitas, são apresentadas apenas as médias dessas três avaliações, para cada cultivar.

Na cultivar Santa Rosa Clorose não houve diferenças entre as plantas quanto à massa da parte aérea nem dos tratamentos inoculados em relação à testemunha quanto às notas. As inoculações foram feitas após a ocorrência dos sintomas de deficiência de ferro, claramente visíveis. O que se poderia pretender então é que as inoculações de bactérias viessem a regredir a deficiência, já manifestada. O que ocorreu aqui, por 
Tabela 9. Massa de matéria seca de parte aérea e raizes de plantas de soja cultivar Santa Rosa inoculadas com diferentes isolados de Pseudomonas spp. fluorescentes e cultivadas em vasos com solo esterilizado ou natural mantidos em casa de vegetação. Médias de cinco repetições.

\begin{tabular}{|c|c|c|c|c|}
\hline \multirow{3}{*}{ Bactérias } & \multicolumn{2}{|c|}{ Parte aérea } & \multicolumn{2}{|c|}{ Raizes } \\
\hline & \multicolumn{4}{|c|}{ Solo } \\
\hline & Esterilizado & Natural & Esterilizado & Natural \\
\hline & $-1-\cdots-11$ & $\cdots-\cdots$ & $\cdots \cdots$ & $\cdots \cdots$ \\
\hline Testemunha & $1,27 \mathrm{a}^{(I)}$ & $1,32 \mathrm{a}$ & 0,51 a & 0,48 a \\
\hline$P s-21-A$ & $1,30 \mathrm{a}$ & $1,79 \mathrm{a}$ & 0,42 a & 0,58 a \\
\hline Ps $-21-B$ & 1,24 a & 1,38 a & 0,46 a & 0,51 a \\
\hline Ps $-21-C$ & 1,34 a & 1,41 a & 0,47 a & 0,45 a \\
\hline Ps-22-A & $1,34 a$ & $1,35 \mathrm{a}$ & 0,43 a & $0,44 a$ \\
\hline Ps-22-B & 1,08 a & 1,80 a & 0,41 a & 0,58 a \\
\hline$P S-23-A$ & 1,24 a & 1,45 a & 0,43 a & 0,53 a \\
\hline$P_{S}-23-B$ & 1,43 a & 1,19 a & 0,45 a & 0,44 a \\
\hline Ps $-23-C$ & 1,34 a & 1,53 a & 0,53 a & 0,57 a \\
\hline Ps $-31-A$ & 1,19 a & 1,45 a & 0,44 a & $0,54 a$ \\
\hline Ps $-31-B$ & 1,21 a & $1,39 \mathrm{a}$ & 0,43 a & $0,46 \mathrm{a}$ \\
\hline PS $-31-C$ & 1,58 a. & 1,44 a & 0,43 a & 0,60 a \\
\hline Ps $-31-D$ & 1,40 a & 1,62 a & 0,48 a & $0,60 a$ \\
\hline Ps -32 & 1,12 a & 1,36 a & 0,39 a & $0,56 \mathrm{a}$ \\
\hline$P s-33$ & 1,29 a & $1,55 \mathrm{a}$ & 0,46 a & 0,58 a \\
\hline$P S-34-A$ & 1,24 a & $1,67 \mathrm{a}$ & 0,42 a & 0,50 a \\
\hline Ps $-34-B$ & $1,57 \mathrm{a}$ & $1,30 \mathrm{a}$ & 0,48 a & 0,49 a \\
\hline Ps $-34-C$ & 1,24 a & $1,30 \mathrm{a}$ & $0,56 \mathrm{a}$ & 0,57 a \\
\hline Ps $-41-A$ & 1,49 a & 1,48 a & 0,43 a & 0,57 a \\
\hline Ps $-41-B$ & 1,14 a & $1,48 \mathrm{a}$ & 0,43 a & 0,50 a \\
\hline Ps $-41-C$ & 1,24 a & $1,53 \mathrm{a}$ & $0,45 \mathrm{a}$ & 0,47 a \\
\hline Ps $-42-A$ & $1,27 \mathrm{a}$ & $1,46 \mathrm{a}$ & 0,59 a & 0,51 a \\
\hline Ps $-42-B$ & 1,39 a & 1,51 a & 0,46 a & 0,47 a \\
\hline Ps $-42-C$ & $1,37 \mathrm{a}$ & 1,51 a & 0,47 a & 0,52 a \\
\hline Ps $-43-A$ & $1,40 \mathrm{a}$ & 1,47 a & $0,41 \mathrm{a}$ & 0,49 a \\
\hline Ps $-43-B$ & $1,25 \mathrm{a}$ & 1,29 a & $0,46 \mathrm{a}$ & 0,45 a \\
\hline Ps $-43-C$ & $1,49 \mathrm{a}$ & 1,48 a & $0,49 a$ & 0,57 a \\
\hline Ps $-44-A$ & $1,36 \mathrm{a}$ & $1,67 \mathrm{a}$ & 0,52 a & 0,53 a \\
\hline Ps $-44-B$ & 1,22 a & $1,28 \mathrm{a}$ & $0,42 \mathrm{a}$ & 0,59 a \\
\hline Ps $-51-A$ & $1,27 \mathrm{a}$ & 1,39 a & 0,55 a & 0,57 a \\
\hline Ps $-51-B$ & 1,25 a & 1,58 a & 0,47 a & 0,52 a \\
\hline Ps $-52-A$ & 1,15 a & 1,43 a & 0,44 a & 0,53 a \\
\hline Ps $-52-B$ & 1,31 a & 1,62 a & $0,53 a$ & 0,58 a \\
\hline Ps $-53-A$ & 1,16 a & 1,38 a & 0,41 a & 0,45 a \\
\hline Ps $-53-B$ & 1,27 a & 1,65 a & 0,44 a & 0,48 a \\
\hline Ps $-53-\mathrm{C}$ & 1,34 a & 1,37 a & 0,53 a & 0,50 a \\
\hline
\end{tabular}

Cont inua... 
Tabela 9. Massa de matéria seca de parte aérea e raízes de plantas de soja cultivar Santa Rosa inoculadas com diferentes isolados de Pseudomonas spp. fluorescentes e cultivadas em vasos com solo esterilizado ou natural mantidos em casa de vegetação. Médias de cinco repetições (Cont inuação)

\begin{tabular}{|c|c|c|c|c|}
\hline \multirow{3}{*}{ Bactérias } & \multicolumn{2}{|c|}{ Parte aérea } & \multicolumn{2}{|c|}{ Raízes } \\
\hline & \multicolumn{4}{|c|}{ Solo } \\
\hline & Esterilizado & Natural & Esterilizado & Natural \\
\hline & \multicolumn{4}{|c|}{ 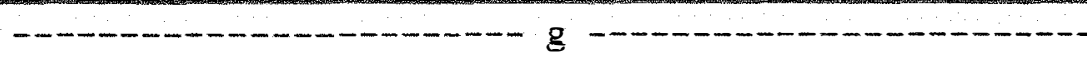 } \\
\hline Ps $-54-A$ & $1,40 \mathrm{a}$ & $1,56 \mathrm{a}$ & 0,47 a & 0,52 a \\
\hline Ps $-54-B$ & 1,49 a & 1,41 a & 0,51 a & $0,47 \mathrm{a}$ \\
\hline Ps $-54-C$ & 1,37 a & 1,65 a & $0,54 a$ & $0,59 a$ \\
\hline $\mathrm{G} 20-18$ & 1,17 a & 1,28 a & $0,53 a$ & $0,46 a$ \\
\hline $136 \mathrm{RN}$ & $1,23 \mathrm{a}$ & 1,28 a & $0,56 a$ & 0,47 a \\
\hline W4F35 & 1,34 a & $1,64 \mathrm{a}$ & 0,58 a & 0,53 a \\
\hline W4F58 & 1,22 a & $1,36 \mathrm{a}$ & $0,52 \mathrm{a}$ & $0,53 \mathrm{a}$ \\
\hline W4F 111 & $1,12 \mathrm{a}$ & $1,40 a$ & $0,42 \mathrm{a}$ & $0,48 \mathrm{a}$ \\
\hline W4F 164 & $1,07 \quad a$ & $1,32 \mathrm{a}$ & $0,49 a$ & 0,54 a \\
\hline W4P5 & $1,45 \mathrm{a}$ & 1,24 a & $0,55 a$ & 0,42 a \\
\hline W4P144 & $1,48 \mathrm{a}$ & $1,20 \mathrm{a}$ & $0,52 a$ & $0,44 \quad a$ \\
\hline Coef. variação & \multicolumn{2}{|c|}{$21,3 \%$} & \multicolumn{2}{|c|}{$24.0 \%$} \\
\hline
\end{tabular}

(1) Médias seguidas de mesma letra na coluna não diferem entre si ao nivel de $5 \%$ pelo teste de Tukey. 
Tabela 10. Avaliação visual por notas de deficiencia de ferro e matéria seca de parte aérea de duas cultivares de soja inoculadas com bactérias fluorescentes do gênero Pseudomonas. Médias de quatro repetiçōes.

\begin{tabular}{|c|c|c|c|c|}
\hline \multirow{2}{*}{$\frac{\text { Cult }}{\text { Bactérias }}$} & \multicolumn{2}{|c|}{ Santa Rosa Clorose } & \multicolumn{2}{|c|}{$T-203$} \\
\hline & Notas 17 & Parte aérea & Notas & Parte aérea \\
\hline & & $-\mathrm{g} / \mathrm{planta-}$ & & -g/parcela- \\
\hline Testemunha & $3,1 \mathrm{ab}^{(2)}$ & 1,54 a & $3,0 a b$ & $2,56 \mathrm{~b}$ \\
\hline Ps-21-A & $4,1 \mathrm{ab}$ & $1,04 \mathrm{a}$ & $2,4 a b c$ & $3,64 a b$ \\
\hline Ps $-21-B$ & $4,0 \mathrm{ab}$ & 1,26 a & $2,3 \mathrm{abc}$ & $4,62 \mathrm{ab}$ \\
\hline Ps $-21-C$ & $2,9 a b$ & 1,88 a & $2,3 a b c$ & $5,49 \mathrm{ab}$ \\
\hline Ps $-22-A$ & $3,2 \mathrm{ab}$ & 2,28 a & $1,8 \mathrm{bc}$ & $8,79 a b$ \\
\hline$P s-22-B$ & $3,7 \mathrm{ab}$ & 1,71 a & $2,0 a b c$ & $6,22 \mathrm{ab}$ \\
\hline Ps $-23-A$ & $3,6 \mathrm{ab}$ & $1,34 \mathrm{a}$ & $1,9 \mathrm{bc}$ & $6,47 \mathrm{ab}$ \\
\hline$P s-23-B$ & $3,8 \mathrm{ab}$ & $1,13 \mathrm{a}$ & $1,6 \mathrm{bc}$ & $9,10 \mathrm{a}$ \\
\hline Ps-23-C & $3,1 \mathrm{ab}$ & $1,56 \mathrm{a}$ & $2,1 \mathrm{abc}$ & $5,94 a b$ \\
\hline Ps $-31-A$ & $3,8 a b$ & $1,28 \mathrm{a}$ & 2,1 abc & $3,52 \mathrm{ab}$ \\
\hline Ps $-31-B$ & $3,5 \mathrm{ab}$ & 2,15 a & $1,3 \mathrm{c}$ & $5,63 \mathrm{ab}$ \\
\hline$P S-31-C$ & $3,0 \mathrm{ab}$ & 1,79 a & $1,9 \mathrm{bc}$ & $6,08 \mathrm{ab}$ \\
\hline Ps $-31-D$ & $4,1 \mathrm{ab}$ & $1,14 \mathrm{a}$ & 2,6 abc & $5,16 a b$ \\
\hline$P s-32$ & $3,3 \mathrm{ab}$ & $1,40 \mathrm{a}$ & $2,6 \mathrm{abc}$ & 2,64 ab \\
\hline Ps -33 & $3,7 \mathrm{ab}$ & 1,29 a & $2,2 \mathrm{abc}$ & $6,28 \mathrm{ab}$ \\
\hline$P S-34-A$ & $2,4 b$ & 2,18 a & $1,6 \mathrm{bc}$ & 6,21 ab \\
\hline Ps $-34-B$ & $3,2 a b$ & $1,61 \mathrm{a}$ & $1,7 \mathrm{bc}$ & $7,43 \mathrm{ab}$ \\
\hline PS $-34-C$ & $3,6 a b$ & 1,34 a & $1,7 \mathrm{bc}$ & $6,68 \mathrm{ab}$ \\
\hline Ps $-41-A$ & $3,2 \mathrm{ab}$ & 1,76 a & $2,0 a b c$ & $6,19 a b$ \\
\hline PS $-41-B$ & $3,7 \mathrm{ab}$ & $1,30 \mathrm{a}$ & $2,2 a b c$ & $6,29 \mathrm{ab}$ \\
\hline Ps $-41-C$ & $3,0 \mathrm{ab}$ & 2,08 a & $2,5 a b c$ & $3,30 \mathrm{ab}$ \\
\hline Ps $-42-A$ & $3,6 \mathrm{ab}$ & 1,43 a & $2,8 \mathrm{ab}$ & $4,30 \mathrm{ab}$ \\
\hline Ps $-42-B$ & $4,1 \mathrm{ab}$ & 0,87 a & $2,8 \mathrm{ab}$ & $5,32 \mathrm{ab}$ \\
\hline Ps $-42-C$ & $3,7 \mathrm{ab}$ & 1,31 a & 3,4 a & $2,50 \mathrm{~b}$ \\
\hline Ps $-43-A$ & $3,2 \mathrm{ab}$ & 1,59 a & $2,5 \mathrm{abc}$ & $4,05 \mathrm{ab}$ \\
\hline Ps $-43-B$ & $3,6 \mathrm{ab}$ & 1,28 a & $1,9 \mathrm{bc}$ & $5,84 \mathrm{ab}$ \\
\hline Ps $-43-C$ & 4,2 a & 0,94 a & $2,6 a b c$ & $4,93 \mathrm{ab}$ \\
\hline PS $-44-A$ & $3,4 \mathrm{ab}$ & $1,75 \mathrm{a}$ & $1,7 \mathrm{bc}$ & $5,27 \mathrm{ab}$ \\
\hline Ps $-44-B$ & $3,4 a b$ & $1,36 \mathrm{a}$ & $1,9 \mathrm{bc}$ & $6,78 \mathrm{ab}$ \\
\hline Coef variação & $34,4 \%$ & $66,0 \%$ & $43,6 \%$ & $43,9 \%$ \\
\hline
\end{tabular}

(1) Notas de 1 (sem sintomas de clorose) a 5 (plantas cloróticas com manchas necroticas).

(2) Médias seguidas da mesma letra, na coluna, não diferem entre si ao nível de $5 \%$ pelo teste de Tukey. 
características genotípicas da própria cultivar $\left(\right.$ MIRANDA $\left.^{1}\right)$, foi variabilidade na manifestação sintomas mesmo dentro de cada parcela. En cada vaso podia haver, e em alguns casos isso realmente ocorreu, plantas com a nota 5, com clorose acentuada e manchas necróticas nas folhas mais jovens, e plantas com a nota 1 , sem qualquer sintoma de deficiência de ferro. Esse fato seguramente contribuiu para que não se detectassem diferença estatísticas entre tratamentos.

Todavia, o sistema de avaliação adotado permitiu que se fizessem algumas observações, não ponderáveis para a Estatística mas claramente visíveis para as pessoas que fizeram as avaliações. Colocaram-se as sementes em 1 inha, procedimento permitido pela área do vaso; como a avaliação foi sempre feita no mesmo sentido nessa linha de plantas, era possivel identificar a nota atribuida a cada planta em particular, comparando-se as três avaliações feitas. Por exemplo, no tratamento de inoculação com o isolado Ps-21-C, atribuiu-se a uma planta a nota 5 na primeira avaliação. Na segunda avaliação a mesma planta recebeu a nota 1 , o que significa que as folhas surgidas após a inoculação desenvolveram-se sem problemas, verdes, sem qualquer sintoma de clorose. Alteraçōes de nota, com diminuição de pelo menos dois pontos entre duas avaliações, ocorreram também em plantas

\footnotetext{
1 MIRANDA, M.A.C. (Instituto Agronômico, Campinas) Comunicação pessoal, 1993.
} 
inoculadas com os isolados Ps-22-B, 23-B, 31-D, 42-A e 43-A. Reafirma-se que esses fenomenos não devem ter se traduzido em diferenças estatisticas por pelo menos dois motivos:

10) A variabilidade genética do material, já comentada. 20) Ainda que não se conheçam as formas pelas quais o ferro seria suprido pelos sideróforos microbianos às plantas, nesse caso, é de se presumir que a reversão dos sintomas de deficiencia do nutriente varie com o grau com que esses sintomas já se manifestaram. Assim, por exemplo, seria mais fácil reverter sintomas com grau de intensidade 3 para 1 que do grau 5 para 3.

Essas observações não estão, em absoluto, destituidas de razão, principalmente quando se consideram os dados referentes à cultivar T-203. O trabalho com essa cultivar iniciou-se pelo menos com duas vantagens em relação ao com a Santa Rosa Clorose. Em primeiro lugar, o material apresenta menor variabilidade na manifestação da clorose por deficiência de ferro induzida por calcário (MIRANDA $\left.{ }^{1}\right)$. Em segundo lugar, no experimento com a $T-203$ a primeira inoculação foi feita antes de que aparecessem os sintomas, numa tentativa justamente de evitar seu aparecimento.

A análise dos dados referentes à cultivar T-203 revela que pelo menos um isolado (Ps-31-B)

1 MIRANDA, M.A.C. (Inst ituto Agronômico, Campinas) Comunicação pessoal, 1993. 
proporcionou nota menor que a testemunha não-inoculada, indicando intensidade dos sintomas significativamente menor. Quanto à massa da parte aérea, outro isolado (Ps-23-B) resultou diferente da testemuna. Esse mesmo isolado apresentou nota baixa $(1,6)$, ainda que não tenha diferido da testemunha. Nessas condições também estão os. isolados Ps-22-A e 34-B, merecendo mais estudos.

Esses resultados todos indicam que, de alguma maneira, a soja utilizou sideróforos microbianos para suprir suas necessidades nutricionais de ferro. Isso já foi relatado para o amendoim, com a aplicação do siderśforo parcialmente purificado (JURKEVITCH et al., 1988) mas não para a soja. Neste caso, fizeram-se três aplicações de $10 \mathrm{ml}$ cada uma de meio $B$ onde a bactéria estava crescendo há 48 horas e onde deveria estar presente o sideróforo. Não se sabe, pois, se a correção ou a inibição dos siniomas de deficiência foram proporcionados pelo próprio sideróforo adicionado com o meio de cultura.ou pelo estabelecimento da bactéria na rizosfera. Esses dois aspectos devem merecer atenção em estudos futuros.

Em trabalho com tomateiros eficientes e ineficientes em ferro, MILLER et al. (1985) relataram que a cultivar ineficiente não foi capaz de utilizar o ferro fornecido pelo ácido rodotorúlico, um sideróforo microbiano. Parece, pois, que a eficiência poderia estar ligada à capacidade da planta de se associar a microrganismos produtores de sideróforos. Esse 
comportamento estaria mais de acordo com a hipótese levantada, mas rejeitada, no experimento com a cultivar Santa Rosa, já discutido.

Neste experimento, todaria, a cultivar T-zo3 foi capaz de se utilizar do sideróforo microbiano, levantando questões interessantes: em condições de campo essas plantas associam-se com bactérias para obter ferro? Nesse caso, as ocorrências de deficiência de ferro na cultivar T-203 deveriam ser registradas em maior número do que se não houvesse essa associação. Caso bactérias e plantas não se associem normalmente a pergunta será outra: por quê?

Os isolados Ps-23-B e Ps-31-B não são, com certeza, os únicos capazes de afetar positivamente a nutrição de plantas de soja. Então, por que não se associariam normalmente? O que deve acontecer, na verdade, é que a microbiota rizosférica mantenha o equilíbrio populacional de seus próprios componentes, permitindo uma expressão limitada da atividade de todos eles, inclusive de isolados com função benéfica como Ps-23-B e Ps-31-B. Nas condições do experimento foi alterado o ambiente de modo a favorecer a expressão desses dois isolados. Isso reafirma o que foi dito no parágrafo anterior: é possível que RPCPS estejam agindo na nutrição de ferro de plantas ineficientes de soja sem que sua atividade seja detectada. Resta agora conhecer os fatores que afetam essas RPCPs de modo a favorecer sua atuação em condições agrícolas. A 
ineficiência em ferro da cultivar T-203 parece ser supria com sideróforos microbianos mas não com fitossideróforos: HOPKINS et al. (1992) cultivaram em conjunto uma cultivar eficiente de aveia le, portanto. produtora de fitossideróforos) e cinco cultirares de soja. com eficiencias em ferro variáveis, e observaram que as cultivares mais ineficientes, entre as quais a $T-203$, não conseguiram utilizar o ferro de fitossideróforos enquanto que as eficientes o fizeram.

\subsection{Testes de antagonismo}

As Tabelas 11 e 12 contêm os resultados dos testes de antagonismo "in vitro" dos 62 isolados bacterianos usados neste trabalho e 24 fungos de solo, patogênicos ou não.

Mais do que cada interação em particular, o interesse na análise das tabelas reside no fato de elas permitirem uma visão razoavelmente ampla da competitividade das bactérias em questão, principalmente com relação a eventuais patógenos.

Alguns isolados de Pseudomonas spp. (Ps-21-A, $21-\mathrm{B}, \quad 22-\mathrm{A}, \quad 31-\mathrm{B}, \quad 34-\mathrm{A}, \quad 34-\mathrm{C}, \quad 42-\mathrm{A}, \quad 42-\mathrm{C}$ e $44-\mathrm{B})$ tiveram at ividade antagônica contra mais de $75 \%$ dos fungos com os quais foram confrontados, outros (Ps-23-A, 23-C, 41-A, 41$\mathrm{B}, 43-\mathrm{A}, 43-\mathrm{B}, 43-\mathrm{C}, 51-\mathrm{B}, 52-\mathrm{A}, 52-\mathrm{B}, 53-\mathrm{A}, 53-\mathrm{C}, 54-\mathrm{A}$, 54-B, 54-C, W4F164 e W4P144) inibiram menos de 25\% dos 
fungos e os restantes tiveram atividade intermediária. Observa-se assim que a atiridade inibitoria de Pseudomonas spp. varia com o fungo considerado, com gradações. sugerindo uma certa especificidade.

O mesmo não se aplica a Bacillus spp. ITabela 12). Entres estes, com a única exceção do isolado ElB, que inibiu cerca de $30 \%$ dos fungos, a inibição ocorreu ou com 90\% (A1A, A3A, D1A, D1B e D1C) ou com menos que 10\% (A2A, A4A, C2A, ( $2 \mathrm{~B}, \quad \mathrm{C} 3 \mathrm{~B}, \mathrm{M1B}, \mathrm{M} 2 \mathrm{~B}, \quad \mathrm{~B} 5 \mathrm{C}, \mathrm{S} 4 \mathrm{~B}$ e $\mathrm{S} 5 \mathrm{~A})$ dos fungos considerados. Esse fato sugere uma atividade mais drástica, um produto menos seletivo, com efeito menos específico. Isso é condizente, de fato, com bactérias que vivem em solo não-rizosférico, onde as condições do ambiente podem exercer efeitos mais severos, em que a entrada de alimentos é bem menor e onde poucos podem sobreviver.

Já com Pseudomonas spp. a grande variação da atividade antagônica sugere mesmo inibição por processos mais específicos, mais seletivos, condizentes com a sua situação de bactérias rizosféricas, ambiente em que, embora haja maior número de competidores, há também maior disponibilidade de alimentos. Nesse ambiente há condições para o desenvolvimento de relações mais sutis, frutos de processos evolutivos conjuntos dos seres que interagem. A esse respeito, notem-se os isolados fúngicos FG-IAC-8-1 e FG-IAC-8-2, ambos saprofíticos e não potencialmente patogênicos. Contra eles, respectiva- 


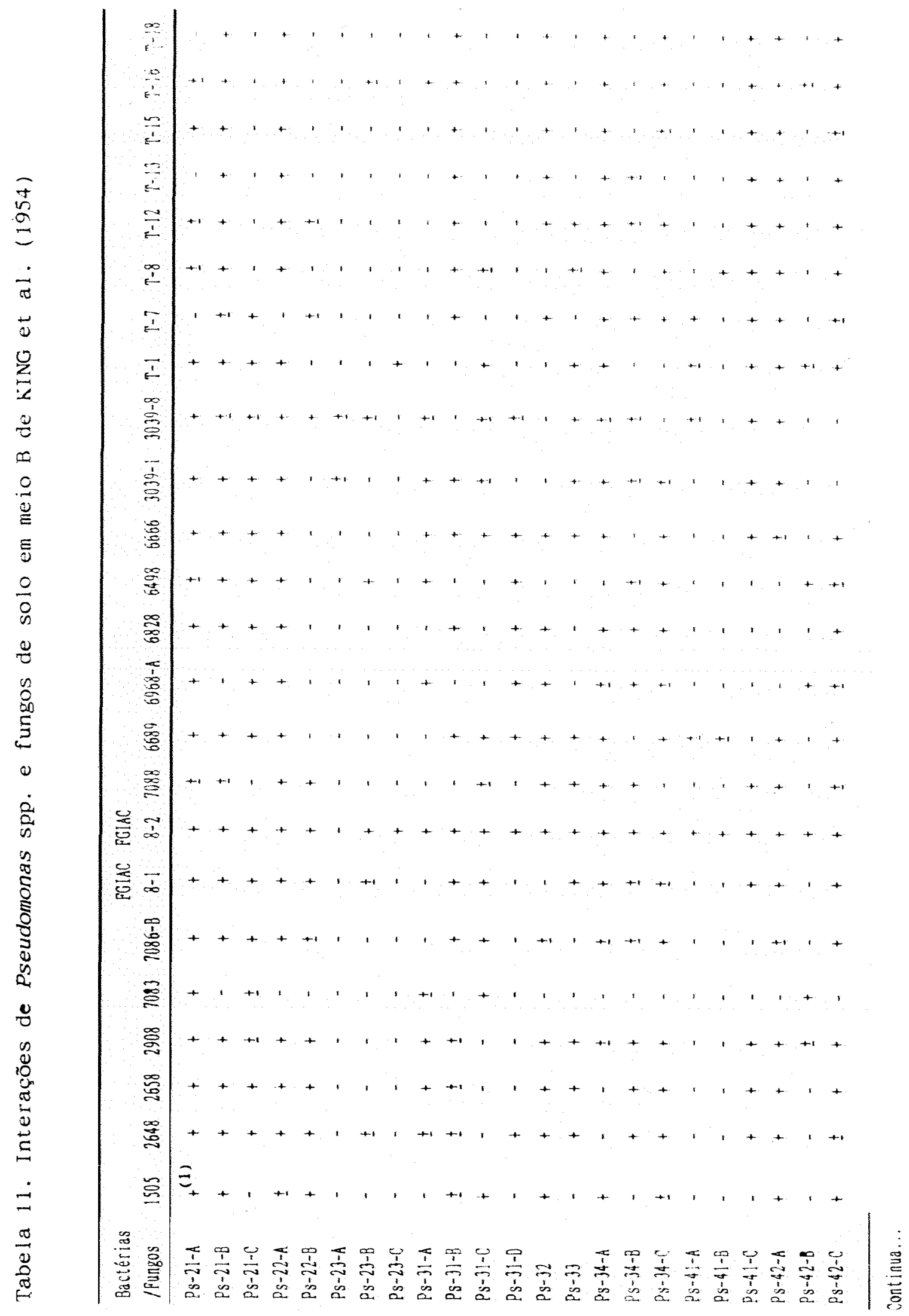




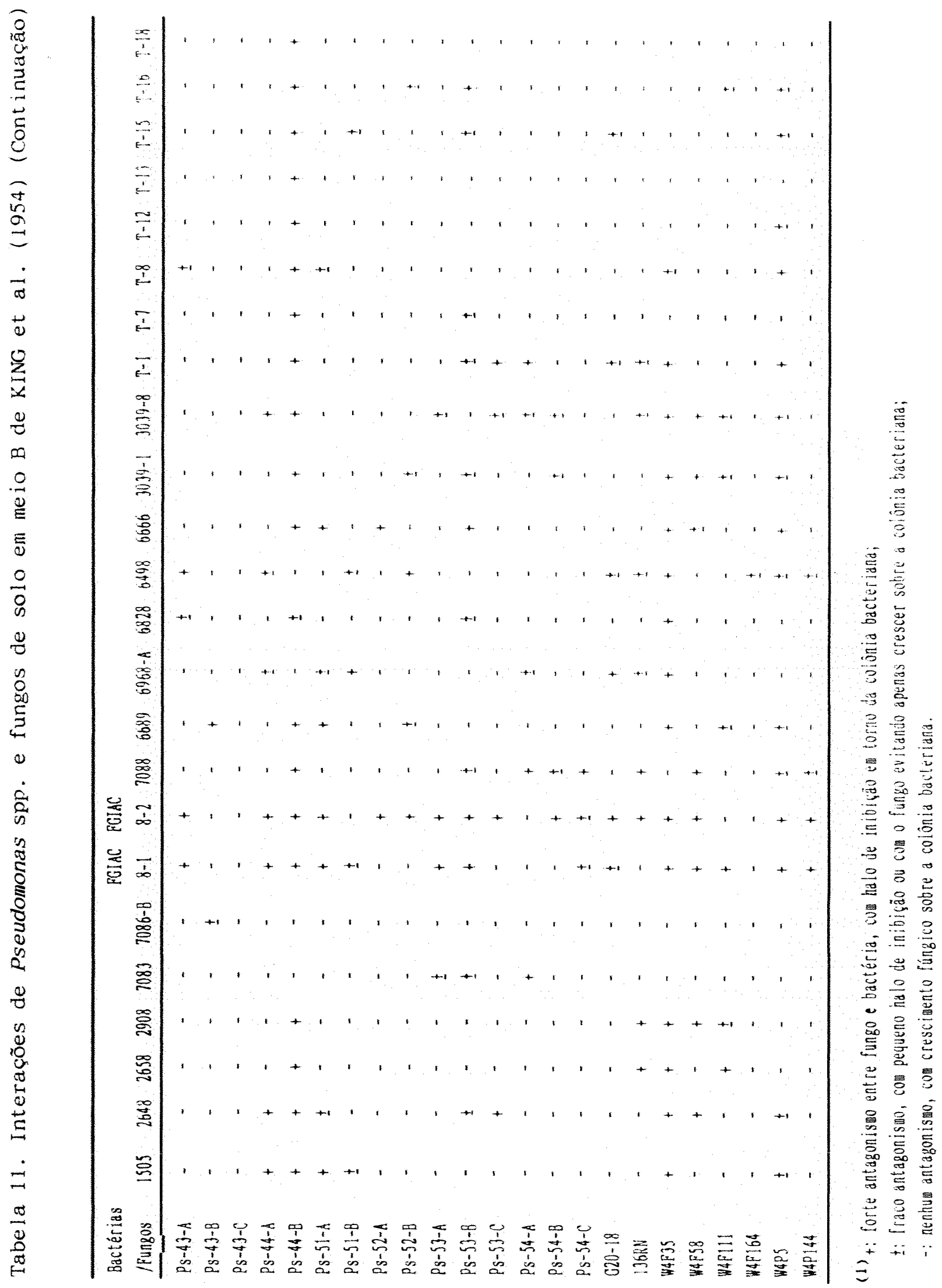




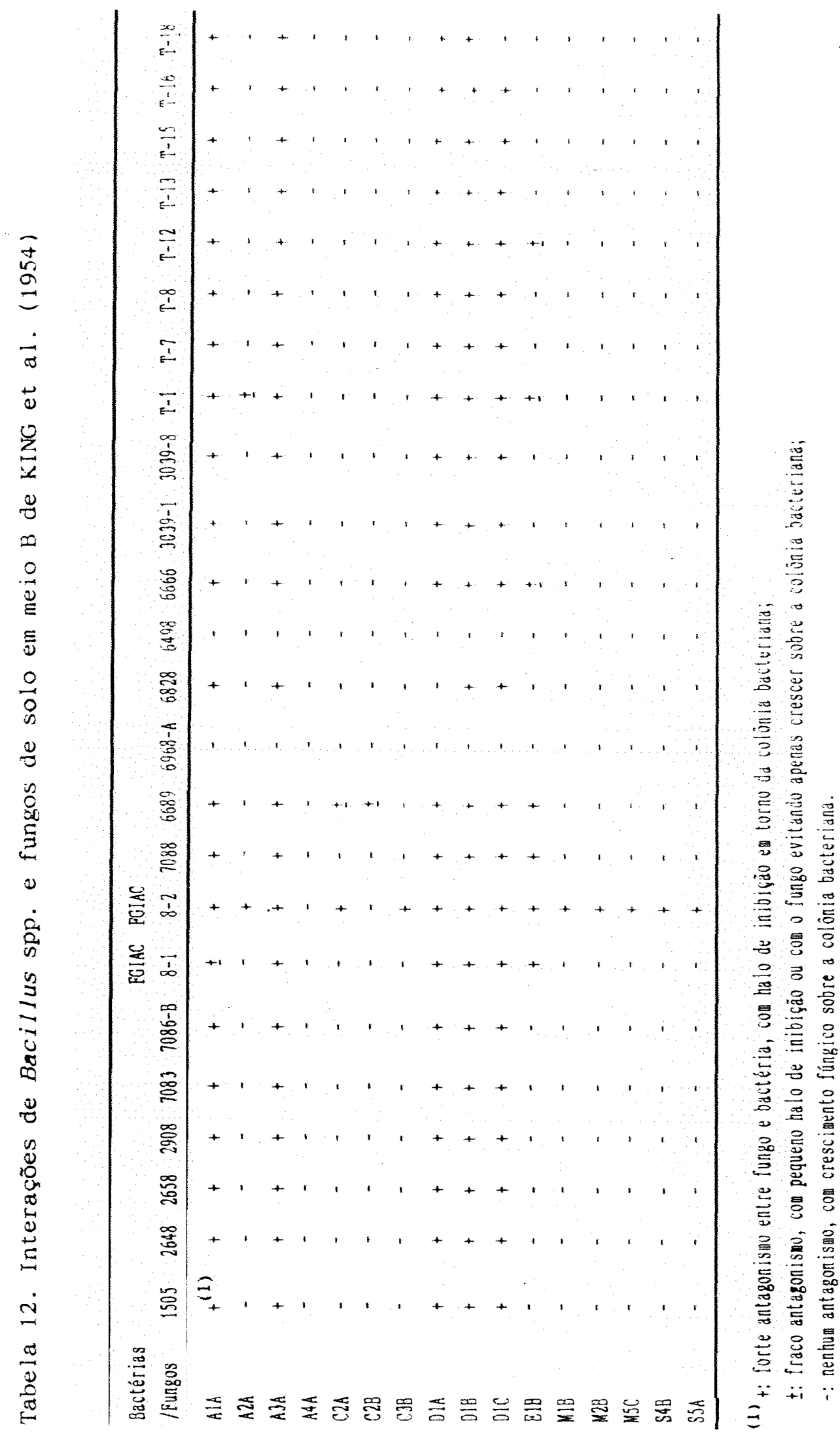


mente, $56 \%$ e $85 \%$ de todos os isolados bacterianos tiveram a lguma atividade antagônica. Isto é: não sendo patógenos esses fungos não tiveram contra si a pressão seletiva da rizosfera, obrigando-os a desenvolver resistência aos muitos competidores que lá habitam.

Não foi possivel neste trabalho correlacionar a atividade antagônica "in vitro" dos isolados de Pseudomonas spp. e Bacillus spp. com suas atividades de promoção de crescimento vegetal ou de prejuízo a ele. Isso é bastante comum na literatura (FREITAS \& PIZZINATTO, 1991). Há aqui a consideração adicional de que os fungos testados "in vitro" pouco provavelmente seriam os mesmos presentes no solo natural utilizado nestes experimentos. 
Tendo em vista os objetivos deste trabalho obter isolados bacterianos benéficos a plantas e identificar os possiveis modos de ação de RPCPs -, pode-se concluir, pelos isolados obtidos, que as rizobactérias podem agir promovendo ou deprimindo o crescimento das plantas.

A promoção do crescimento pode se dar por interação com micorrizas. Algumas evidências sugerem que podem atuar fornecendo ferro a plantas crescendo em condições de baixa disponibilidade de ferro, havendo necessidade de mais estudos a respeito. Rizobactérias também interagem com fitopatógenos "in vitro".

Em certas situações, rizobactérias podem ser deletérias às plantas, com variados graus de prejuízo. 


\section{REFERÊNCIAS BIBL IOGRÁFICAS}

AKERS, H.A. Multiple hydroxamic microbial iron chelators (siderophores) in soil. Soil Science, Baltimore, 135: $156-160 . \quad 1983$.

ALBERT, F. \& ANDERSON, A.J. The effect of Pseudomonas putida colonization on root surface peroxidase. Plant Physiology, Lancaster, 85(2): 537-542. 1987.

AMBLER, J.R. \& YOUNG, J.L. Techniques for determining root lenght vesicular - arbuscular mycorrhizae. Soil Science Society American Journal, Madison, 41: 551-556, 1977 .

AMES, R.; REID, C.P.P. \& INGHAM, E.R. Rhizosphere bacterial population responses to root colonization by a vesicular - arbuscular mycorrhizal fungus. New Phytol, Cambridge, 96: 555-563. 1984.

ANDERSON, A.J. Isolation from root and shoot surfaces of agglutinins that show specificity for saprophytic 
pseudomonads. Canadian Journal of Botany, Ottawa, 61: $3438-3443 . \quad 1983$.

ARSHAD, M. \& FRANKENBERGER Jr, W.T. Microbial production of plant hormones. P1. Soil, The Hague, 133(1): 1-8. 1991.

AZCÓN-AGUILAR, R.C. \& BAREA, J.M. Effects of plant hormones present in bacterial cultures on the formation and responses to VA mycorrhiza. New Phytologist, Oxford, 80: 359-364. 1978 .

AZCON-AGUILAR, C. \& BAREA, J.M. Effect of soil microorganisms on formation of vesicular - arbuscular mycorrhyzas. Transactions of the British Mycological Society, London, 84(3): 536-537, 1985.

AZCÓN-AGUILAR, C. ; DIAZ-RODRIGUEZ, R.M. \& BAREA, J.M. Effect of soil micro-organisms on spore germination and growth of the vesicular - arbuscular mycorrhizal fungus Glomus mosseae. Transactions of the British Mycologial Society, London, 86(2): $337-340$. 1986.

BAGG, A. \& NEILANDS, J.B. Molecular mechanism of regulation of siderophore - mediated iron assimilation. Microbiological Reviews, Washington, 51(4): 509-518. 1987 . 
BAKKER, P.A.H.M.: BAKKER, A.W.; MARUGG, J.D.; WEISBEEK, P.J. \& SCHIPPERS, B. Bioassay for studying the role of siderophores in potato growth stimulation by Pseudomonas spp. in short potato rotations. Soil Biol. Biochem., Oxford, 19(4): 443-449. 198?.

BAKKER, A.W. \& SCHIPPERS, B. Microbial cyanide production in the rhizosphere in relation to potato yield reduction and Pseudomonas spp. - mediated plant growth stimulation. Soil Biol. Biochem., Oxford, 19:451-457. 1987.

BAR-NESS, E.; HADAR, Y.; CHEN, Y.; RÖMHELD, V. \& MARSCHNER, H. Short-term effects of rhizosphere microrganisms on Fe uptake from microbial siderophores by maize and oat. P1. Physiol., Washingt on, 100(1): 451-456. 1992.

BASHAN, Y.; SINGH, M. \& LEVANONY, H. Contribution of Azospirillumbrasilense cd to growth of tomato seedlings is not through nitrogen fixation. Can. J. Bot., Ottawa, $67(8): 2429-2434.1989$.

BECKER, J.O.; COOK, R.J. Role of siderophores in suppression of Pythium species and production of increased - growth response of wheat by fluorescent pseudomonads. Phytopatology, St. Paul, 78(6): 778-782. 1988. 
BOLTON Ji, H. \& ElliotT: L.F. Toxin production by a rhizobacterial Pseudomonas sp. that inhibits wheat root growth. Pl. Soil, The Hague, 114(2): 269-278. 1989.

BOSSIER, P. \& VERSTRAETE, W. Ecology of Arthrobacter JG-9detectable hydroxamate siderophores in soils. Soil Bio1. Biochem., Oxford, 18(5): 487-492. 1986.

BRANDão, E.M. Isolamento e seleção de rizobactérias promotoras do crescimento em milho. Piracicaba: 1989. 133p. (Mestrado ESALQ/USP).

BRI SBANE, P.G.; HARRIS, J.R. \& MOEN, R. Inhibition of fungi from wheat roots by Pseudomonas fluorescens 2-79 and fungicides. Soil Biol. Biochem.: Oxford, 21(8): 10.19-1025. 1989.

BRown, M.E. Plant growth substances produced by microorganisms of soil and rhizosphere. J. Appl. Bacteriol., London, 35: 443-451. 1972 .

BROWN, M.E. Seed and root bacterization. Annual Review of Phytopathology, Palo Alto, 12:181-197. 1974.

BROWN, J.C. \& AMBLER, J.E. I ron stress response in tomato. I. Sites of Fe reduction, absorption, and transport. Physiol. Plant., Copenhagen, 31: 221-224. 1974. 
BROWN, M.E.; BURLINGHAM, S.K. \& JACKSON, R.M. Studies on Azotobacter species in soil. II. Populations of Azotobacter in the rhizosphere and effects of artificial inoculation. Plant and Soil. The Hague, 17: 320-332. 1962.

BROWN, M.E.; BURLINGHAM, S.K. \& JACKSON, R.M. Studies on Azotobacter species in soil. III. Effects of artificial inoculation on crop yields. Plant and soil, The Hague, 20: 194-214. 1964.

BROWN, M.E.; JACKSON, R.M. \& BURLINGHAM, S.K. Effects produced on tomato plants, Lycopersicon esculentum, by seed on root tratment with gibberelic acid and indolyl3-acetic acid. J. Exp. Bot., 19: 544-552. 1968.

BULl, C.T.; WELLER, D.M. \& THOMASHOW, L.S. Relationship between root colonization and suppression of Gaeumannomyces graminis var. tritici by Pseudomonas fluorescens strain 2-79. Phytopatology, St. Paul, $81(9): 954-959 . \quad 1991$.

BURNHAM, B.F.; NEILANDS, J.B. Studies of the metabolic function of the ferrichrome compounds. Journal of Biological Chemistry, Baltimore, 236: 554-559. 1961. 
BURR, J.J. \& CAESAR, A. Beneficial plant bacteria. CRC Critical Reviews in Plant Sciences, Boca Raton, 2(1): 120. 1985 .

BURR, T.J.; SCHROTH, M.N. \& SUSLOW, T. Increased potato yields by tratment of seedpieces with specific strains of Pseudomonas fluotescens and P. putida. Phytopatology, St. Paul, 68: 1377-1383. 1978 .

CAESAR, A.J. \& BURR, T.J. Growth promotion of apple seedlings and rootstocks by specific strains of bacteria. Phytopatology, St. Paul, 77(11): 1583-1588. 1987.

CARDOSO, E.J.B.N. \& FREITAS, S.S. Microbiologia da rizosfera. In: MONIZ, A.C.; FURLANI, M.C.; FURLANI, P.R. \& FREITAS, S.S. (eds.) A responsabilidade social da ciência do solo. Campinas, SBCS. 1988. p.389-401.

CARDOSO, E.J.B.N. \& FREITAS, S.S. A rizosfera. In: CARDOSO, E.J.B.N.; TSAI, S.M. \& NEVES, M.C.P. Microbiologia do solo, Campinas, Sociedade Brasileira de Ciência do Solo, 1992. p. 42-57.

CARRILLO, G.C. \& VAZQUES, M.R.G. Comparative study of siderophore - like activity of Rhizobium phaseoli and 
Pseudomonas fluorescens. J. Pl. Nutrition, New York, $15(5): 579-590 . \quad 1992$.

CHAN, E.C.S. \& RATZNEISON, H. Growth of Arthrobacter globiformis and Pseudomonas sp. in relation to the rizhosphere effect. Can. J. Microbio1., 7: 759-767. 1961 .

CHERRINGTON, C.A. \& ELLIOTT, L.F. Incidence of inhibitory pseudomonads in the Pacific Northwest. Pl. Soil, The Hague, $101(2): 159-165.1987$.

CIANZIO, S.R.; FEHR, W.R. \& ANDERSON, I.C. Genotypic evaluation for iron deficiency chlorosis in soybeans by visual scores and chlorophyll concentration. Crop Sci., Madison, 19: 644-646. 1979 .

COOPER, R. Bacterial fertilizers in the Soviet Union. Soils and Fertilizers, Harpenden, 22(5): 327-333. 1959.

CosTA, A.S. \& SOUZA, D.M. Clorose do arroz devida à deficiência de ferro em solo latosol roxo de Campinas. Summa Phytopathologica, Piracicaba, 2(2): 115-121. 1976 .

CURL, E.A. \& TRUELOVE B. The rhizosphere. Berlim, Springer-Verlag, 1985.288 . 
DATTA, M.; BANIK, S. \& GUPTA R.K. Studies on the efficacy of a phytohormone producing phosphate solubilizing Bacillus firmus in augmenting paddy yield in acid soil of Nagaland. Pl. Soi 1, The Hague, 69: 365-3-3. 1982.

DUNLEAVY, J. Control of damping-off of sugar beet by Bacillus subtilis. Phytopathology, St. Paul, 45: 252258. 1955 .

EKLUND, E. Secondary effects of some pseudomonads in the rhizoplane of peat grown cucumber plants. Acta Agr. Scand., Suppl., Estocolme, 17:1-57..1970.

ELAD, Y. \& CHET, I. Possible role of competition for nutrients in biocontrol of Pythium damping-off by bacteria. Phytopathology, St. Paul, 77(2): 190-195. 1987 .

ELLIOT, L.F. \& LYNCH, J.M. Pseudomonads as a factor in the growth of winter wheat (Triticum aestivum L.). Soil. Bio1. Biochem., Oxford, 16:69-71. 1984.

FAQUIM, V. Cinética da absorção de fosfato, nutrição mineral, crescimento e produção de soja sob influência de micorriza vesículo-arbuscular (MVA). Piracicaba, 1988. 136p. (Doutorado - Escola Superior de Agricultura "Luiz de Queiroz"/USP). 
FRANKENBERGER JT., W.T. \& POTH, M. L-tryptophan transaminase of a bacterium isolated from the rhizosphere of Festuca octoflora (Gramineae) Soil Biol. Biochem., Oxford, 20(3): 299-304. 1988.

FREDRICKSON, J.K. \& ELLIOTT, L.F. Colonization of winter wheat roots by inhibitory rhizobacteria. Soil science Society of America Journal, Madison, 49(5): 1172-1176. 1985 .

FREITAS, S.S. Desenvolvimento de plântulas de café pela inoculação de Pseudomonas sp. R. bras. Ci. Solo, Campinas, 13: 31-34. 1989.

FREITAS, J.R. \& GERMIDA, J.J. Growth promotion of winter wheat by fluorescent pseudomonads under field conditions. Soil Biol. Biochem, Oxford, 24(11): 11371146.1992.

FREITAS, S.S. \& PIZZINATTO, M.A. Interações de Pseudomonas sp. e Fusarium oxysporumf. sp. lycopersici na rizosfera de tomateiro (Lycopersicon esculentum). Summa Phytopathologica, Jaguariúna, 17(2): 105-112. 1991 .

GAMLIEL, A. \& KATAN, J. Suppression of major and minor pathogens by fluorescent pseudomonads in solarized and 
nonsolarized soils. Phytopathology, St. Paul, 83(1): $68-75 . \quad 1993$

GAMO, T. Azospirillum spp. from crop roots: A promoter of plant growth. Japan Agricultural Research Quarterly (JARQ), Tóquio, 24(4): 253-259. 1991 .

GANESAM, P. \& GNANAMANICKAM, S.S. Biological control of Sclerotium rolfsii Sacc. in peanut by inoculation with Pseudomonas fluorescens. Soil Biol. Biochem., Oxford, 19(1): $35-38.1987$.

GLANDORF, D.C.M.; PETERS, L.G.L.; VAN DER SLUIS, I.; BAKKER, P.A.H.M. \& SCHIPPERS, B. Crop specificity of rhizosphere pseudomonads and the involvement of root agglutinins. Soil Biol. Biochem, Oxford, 25(8): $981-$ 989. 1993.

GRAHAM, J.H. Interactions of mycorrhizal fungi with soilborne plant pathogens and other organisms: an introduction. Phytopathology, St. Paul, 78(3): 365-366. 1988

GRAHAM, J.H.; LEONARD, R.T. \& MENGE, J.A. Membrane mediated decrease in root exudation responsible for phosphorus inhibition of vesicular - arbuscular 
mycorrhiza formation. Plant Physiology, Lancaster, 68: 548-552. 1981 .

H.ANDAM, H.; THOMASHOW, L.S. \& WELLER, D.M. Relative importance of fluorescent siderophore and phenazine antibiotic by Pseudomonas fluorescens $2-79$ in suppression of take-all. Phytopathology, St. Paul, 78(12): 1522 (abstract). 1988 .

HARRISON, L.A.; LETENDRE, L.; KOVACEVICH, P.; PIERSON, E. \& WELleR, D. Purification of an antibiotic effective against Gaeumannomyces graminis var. tritici produced by a biocontrol agent, Pseudomonas aureofaciens. Soil Biol. Biochem, Oxford, 25(2): 215-221. 1993.

HEBBAR, K.P.; DAVEY, A.G. \& DART, P.J. Rhizobacteria of maize antagonistic to Fusarium moniliforme, a soil-borne fungal pathogen: isolation and identification. Soil Bio1. Biochem., Oxford, 24(10): 979-987. 1992a.

HEBbaR, K.P.; DAVEY, A.G.; MERRIN, J. \& DART, P.J. Rhizobacteria of maize antagonistic to fusarium moniliforme, a soil-borne fungal pathogen: colonization of rhizosphere and roots. Soil Biol. Biochem., Oxford, 24(10): 989-997. 1992b. 
HILTNER, L. Über neuere Erfahrungen und Probleme auf dem Gebiet der Bodenbakteriologie unter besonderer Berücksichtigung der Gründüngung und Brache. Arb. Deut. Landwirtsch. Ges., Berlin, 98:59-78, 1904.

HOHNADEL, D. \& MEYER, J-M. Specificity of pyoverdinemediated iron uptake among fluorescent Pseudomonas strains. J. Bacteriol, Baltimore, 170(10): 4865-4873. 1988 .

HOPKINS, B.G.; JOLLEY, V.D. \& BROWN, J.C. Variable inhibition of iron uptake by oat phytosiderophore in five soybean cultivars. J. Pl. Nutrition, New York, $15(1): 125-135 . \quad 1992$.

HOWELL, C.R. \& OKON, Y. Recent results of greenhouse and field trials on bacterial-induced plant growth promotion with no obvious symptoms of plant disease. In: INTERNATIONAL WORKSHOP ON PLANT GROWTH - PROMOTING RHIZOBACTERIA, I. Orillia, 1987. Proceedings. Orillia, KLOEPPER, J . 1987 . p.29-33.

HOWELL, C.R. \& STIPANOVIC, R.D. Supression of Pythium ultimum - induced damping-off of cotton seedlings by Pseudomonas fluorescens and its antibiotic, pyoluteorin. Phytopathology, St. Paul, 70:712-715. 1980. 
JOLLEY, V.D. \& BROWN, J.C. Differential response of Feefficient corn and Fe-inefficient corn and oat to phytosiderophore released by Fe-efficient Coker 227 oat. J. P1. Nutrition, New York, 14(1): 45-58. 1991 .

JURKEVITH, E. ; HADAR, Y. \& CHEN, Y. Involvement of bacterial siderophores in the remedy of lime-induced chlorosis in peanut. Soil Sci. Soc. Am. J., Madison, $52(4): 1032-1037.1988$.

KEEL, L.; VOISARD, C.;BERLING, C.H.; KAHR, G.\& DEFAGO, G. Iron sufficiency, a prerequisite for the suppression of tobaccoblack root rot by Pseudomonas fluorescens strain CHAO under gnotobiotic conditions. Phytopathology, st. Paul, 79(5): 584-589. 1989 .

KIM, D.H. \& MISAGHI, I.J. Siderophore production by fluorescent pseudomonads is sensitive to changes in atmospheric $\mathrm{O}_{2}$ and $\mathrm{CO}_{2}$ concentrations. Soil Biol. Biochem., Oxford, 24(8): 821-824. 1992.

KING, E.O.; WARD, M.K. \& RANEY, D.E. Two simple media for the demonstration of pyocyanin and fluorescin. J. Lab. Clin. Med., St. Louis, 44(2): 301-307. 1954.

KLOEPPER, J.W. Development of in vivo assays for prescreening antagonists of Rhizoctonia solani on 
cotton. Phytopathology, St. Paul, 81(9): 1006-1013. 1991.

KLOEPPER, J.W.; LEONG, J. ; TEINTZ, M. \& SCHROTH, M.N. Enhanced plant growth by siderophores produced by plant growth promoting rhizobacteria. Nature, London, 286: $885-886.1980$.

KLOEPPER, J.W. \& SCHROTH, M.N. Plant growth-promoting rhizobacteria on radishes. Int. Conf. Plant Pathogenic Bacteria, IV, Angus, 1978. Proceedings, 2: 879-882. 1978 .

LALANDE, R.; BISSONNETTE, N.; COUTLEE, D. \& ANTOUN, H. Identification of rhizobacteria from maize and determination of their plant-growth promoting potential. P1. Soil, The Hague, 115(1): 7-11. 1989 .

LEONG, J. Siderophores: Their biochemistry and possible role in the biocontrol of plant pathogens. Ann. Rev. Phytopathol., Palo Alto, 24: 187-209. 1986.

LEYVAL, C. \& REID, C.P.P. Utilization of microbial siderophores by mycorrhizal and non-micorrhizal pine roots. New Phytol., Oxford, 119(1): 93-98. 1991. 
LIFSHITZ, R. \& RENNIE. R.J. Mechanisms of bacterialinduced plant growth promotion in the absence of disease symptoms: Physiology and molecular biology. In: INTERNATIONAL WORKSHOP ON PLANT GROWTH-PROMOTING RHIZOTOBACTERIA， I . Oril1 i a, KLOEPPER, J . 1987. p. $41-43$.

MACDONALD, J.C. \& BOCK, A. Spectral properties of pseudobactin produced by pseudomonas sp. BIO. Can. J. Bot., Ottawa, 65(4): 703-705. 1987.

MARTINEZ-TOLEDO, M.V.; RUBIA, T.; MORENO, J. \& GONZALEZLOPEZ, J. Root exudates of Zea mays and production of auxins, gibberellins and cytokinins by Azotobacter chroococcum. Pl. Soil, The Hague, 110(1): 149-152. 1988 .

MENGEL, K. \& KIRKBY, E.A. Principles of Plant Nutrition. 4a ed. Bern, International Potash Institute, 1987. $687 \mathrm{p}$.

MEYER, J.M. \& ABDALLAH, M.A. The fluorescent pigment of Pseudomonas fluorescens: biosynthesis, purification and physicochemical properties. Journal of General Microbiology, Oxford, 107:319-328. 1978. 
MEYER, J.M. \& HORNSPERGER, J.M. Role of pyoverdinepf, the iron-binding fluorescent pigment of Fseudomonas fluorescens, in iron transport. J. Gen. Microbiol., Oxford, 107: 329-331. 1978 .

MEYER, J.R. \& LINDERMAN, R.G. Response of subtertanean clover to dual inoculation with vesicular-arbuscular micorrhizal fungi and a plant growth-promoting bacterium, Pseudmonas putida. Soil Biol. Biochem., Oxford, 18(2): 185-190. 1986a.

MEYER, J.R. \& LINDERMAN, R.G. Selective influence on populations of rhizosphere or rhizoplane bacteria and actinomycetes by mycorrhizas formed by Glomus fasciculatum. Soil Biol. Biochem., Oxford, 18(2): 191196. 1986b.

MILlER, G.W.; PUSHNIK, J.C. ; EMERY, T.E.; JOLLEY, V.D. \& WARNIK, K.Y. Uptake and translocation of iron from ferrated rhodotorulic acid in tomato. J. Plant. Nutr., New York, 8: 249-264, 1985 .

MISAGHI, I.J. ; OLSEN, M.W. ; COTTY, P.J. \& DONNDELINGER, C.R. Fluorescent siderophore - mediated iron deprivation - a cont ingent biological control mechanism. Soil Biol. Biochem., Oxford, 20(4): 573-574. 1988 . 
MOZAFAR, A.; DUSS, F. \& OERTLI, J.J. Effect of Pseudomonas fluorescens on the root exudates of two tomato mutants differently sensitive to Fe chlorosis. Pl. Soil, The Hague, 144(2): 167-176. 1992 .

MURPHY, T.P.; LEAN, D.R.S. \& NALEWAJAKO, C. Blue-green algae: Their excretion of iron-seletive chelators enables them to dominate other algae. Science, Washington, 192:900-902. 1976.

OLSEN, N.W. \& MISAGHI, I.J. Plant growth promoting activity of heat-killed cells of Pseudomonas fluorescens, Phytopathology, St. Paul, 71: 1006. 1981.

ONYEZILI, F.N. \& RøS, J.D. Iron deficiency stress responses of five graminaceous monocots. J. Pl. Nutrition, New York, 16(5):953-974. 1993.

ORDENTLICH, A.; ELAD, Y. \& CHET, I. The role of chitinase of Serratia marcescens in biocontrol of sclerotium rolfsii. Phytopathology, St. Paul, 78(1): 84-88. 1988.

PAAU, A.S. \& MCINTYRE, J.L. Development of PGPR inoculants: Challenges and priorities. In: INTERNATIONAL WORKSHOP ON PLANT GROWTH - PROMOTING RHI IZOBACTERIA, I . Orillia, $1987 . \quad$ Proceedings . Orillia, KLOEPPER, J. 1987. p.44-49. 
PAPASTYLIANOU, I. Effect of selected soil factors on chlorosis of peanut plants grown in calcareous soils in Cyprus. P1. Soil, The Hague, 117(2): 291-294. 1989.

PAPASTYLIANOU, I. Timing and rate of iron chelate application to correct chlorosis of peanut. J. Pl. Nutrition, New York, 16(7): 1193-1203. 1993.

PARK, C-S., PAULITZ, T.C. \& BAKER, R. Biocontrol of Fusarium wilt of cucumber resulting from interactions between Pseudomonas put ida and nonpathogenic isolates of Fusarium oxysporum. Phytopathology, St. Paul, 78(2): $190-194.1988$.

PAULITZ, T.C. \& LINDERMAN, R.G. Interactions between fluorescent pseudomonads and VA mycorrhizal fungi. New Phyto1., Cambridge, 113(1): 37-45. 1989.

PAULITZ, T.C. \& LOPER, J.E. Lack of a role for fluorescent siderophore production in the biological control of Phyt ium damping-off cucumber by a strain of Pseudomonas putida. Phytopathology, St. Paul, 81(8): 930-935. 1991 .

PHILLIPS, J.M. \& HAYMAN, D.S. Improved procedure for clearing roots and staining parasitic and vesicular arbuscular micorrhizal fungi for rapid assessment of 
infection. Transactions British Mycological Society, London, 55: 158-161, 1970.

PHILSON, S.B. \& LLiNAS, M. Siderochromes from Pseudomonas fluorescens. J. Biol. Chem., Baltimore, 257:8081-8085. 1982

PIERSON III, L.S. \& THOMASHOW, L.S. Role of phenazine antibiotics produced by Pseudomonas aureofaciens 30-84 in take-all suppression. Phytopathology, St. Paul, 78(12): 1522 (abstract). 1988.

RAYMOND, K.N.; MULlER, G. \& MATZANKE, B.F. Complexat ion of iron by siderophores: A review of their solution and structural chemistry and biological function. Topics Curr. Chem., 123:49-102. 1984 .

REID, C.P.P.; SZANISZLO, P.J. \& CROWLEY, D.E. Siderophore involvement in plant iron nutrition. In: SWINBURNE, T.R. (ed.) Iron siderophores and plant disease. New York, Plenum Publishing Corporation. 1986. p.29-42.

RöMHELD, V. Different strategies for iron aquisition in higher plant. Physiol. Plant., Copenhagen, 70: 231-234. 1987. 
RöMHELD, $V . \&$ MARSCHNER, H. Mechanisms of iron uptake by peanut plants. Plant Physiol., Lancaster, 71: 949-954. 1983.

RöMHELD, V. \& MARSCHNER, H. Evidence for the existence of a specific uptake system for iron phytosiderophores in roots of grasses. Plant Physiol., Lancaster, 80: 175180. 1986.

ROUATT, J.W. \& KATZNELSON, H. A study of the bacteria on the root surface and in the rhizosphere of crop plants. J. App 1. Bact., London, 24:164-171. 1961 .

ROUATT, J.W.; KATZNELSON, H.\& PAYNE, Y.B. Statistical evaluation of the rhizosphere effect. Proc. Soil Sci. Soc. Am., 24: 271-273. 1960 .

SARRUGE, J.R. \& HAAG, H.P. Análises químicas em plantas. Piracicaba, Departamento de Química, ESALQ/USP, 1974. ( Mimeografado)

SCHER, F.M. \& BAKER, R. Effect of Pseudomonas putida and a synthetic iron chelator on the induction of soil suppressiveness to Fusarium wilt pathogens. Phytopathology, St. Paul, 72: 1567-1573. 1982. 
SCHER, F.M. \& SCHROTH, M.N. Environmental aspects of growth promotion. In: INTERNATIONAL WORKSHOP ON PLANT GROWTH-PROMOT ING RHIZOBACTERIA， I . Oril1 ia， 1987. Proceedings. Orillia, KLOEPPER, J. 1987. p.34-36.

SCHIPPERS, B . \& LUGTENBERG, B. Mechanisms of biological control by rhizobacteria: Physiology and molecular biology. In: INTERNATIONAL WORSHOP ON PLANT GROWTHPROMOTING RHIZOBACTERIA， I . Orillia， 1987. Proceedings. Orillia, KLOEPPER, J. 1987. p.23-28.

SILVEIRA, A.P.D. \& CARDOSO, E.J.B.N. Influência do tipo de solo e de fungo micorrízico vesículo-arbuscular no desenvolvimento de três cultivares de feijão. R. bras. Ci. Solo, Campinas, 11: 37-43, 1987 .

SIMEONI, L.A.; LINDSAY, W.L. \& BAKER, R. Critical iron level associated with biological control of Fusarium wilt. Phytopathology, St.Paul, 77(7): 1057-1061, 1987.

SIVAMANI, E. \& GNANAMANICKAM, S.S. Biological control of Fusatium oxysporim f. sp. cubense in banana by inoculation with Pseudomonas fluorecens. Pl. Soil, The Hague, $107(1): 3-9.1988$. 
STANIER, R.Y.; PALLERONI, N.J. \& DOUDOROFF, M. The aerobic pseudomonads: a taxonomic study. J. Gen. Microbiol., $43(2): 159-271 . \quad 1966$.

SUSLOW, T.V. \& SCHROTH, M.N. Rhizobacteria of sugar beets: Effects of seed application and root colonization on yield. Phytopathology, St. Paul, 72: 199-206. 1982.

TANAKA, R.T.; MASCARENHAS, H.A.A.; MIRANDA, M.A.C.; DEGASPARI, N. \& CARMELLO, Q.A.C. Deficiência nutricional em soja cultivada em solo de cerrado devido à incorporação superficial do calcário. O Agronômico, Campinas, 41(3): 231-241. 1989 .

THOMASHOW, L.S.; PIERSON III, L.S.; WELlER, D.M.\& BONSALL, R.F. Detection of phenazine antibiotcs produced by Pseudomonas spp. in soil. Phytopathology, St. Paul, 78(12): 1522. (abstract). 1988 .

TIEN, T.M.; GASKINS, M.K. \& HUBBELL, D.H. Plant growth substances produced by Azospirillum brasilense and their effect on the growth of pearl millet (Pennisetum americanum L.). Appl. Environ. Microbiol., Baltimore, 37 : $1016-1024.1979$. 
TREEBY, M.T. The role of mycorrhizal fungi and nonmycorrhizal micro-organisms in iron-nutrition of citrus. Soil Biol. Biochem., Oxford, 24(9): 857-864. 1992.

TREEBY, M.; MARSCHNER, H. \& RöMHELD, V. Mobilization of iron and other micronutrient cations from a calcareous soil by plant-borne, microbial, and synthetic metal chelators. P1. Soil, The Hague, 114(2): 217-226. 1989.

WELLER, D.M. \& ZABLOTOWICZ, R. Recent results from field and greenhouse trials on biological controls of diseases with obvious visual and typical symptoms. In: INTERNATIONAL WORKSHOP ON PLANT GROWTH-PROMOTING RHIZOBACTERIA, I. Orillia, $1987 . \quad$ Proceedings. Oril1 ia, KLOEPPER, J . 1987. p.10-16.

WHITE, P.F. \& ROBSON, A.D. Rhizosphere acidification and $\mathrm{Fe}^{3+}$ reduction in lupins and peas: Iron deficiency in lupins is not due to a poor ability to reduce $\mathrm{Fe}^{3+}$. Pl. Soil, The Hague, 119(1): 163-175. 1989 .

WHITE, P.F. \& ROBSON, A.D. Response of lupins (Lupinus angustifolius L.) and peas (Pisum sativum L.) to Fe deficiency induced by low concentrations of $\mathrm{Fe}$ in solution or by addition of $\mathrm{HCO}_{3}{ }^{-}$. Pl. Soil, The Hague, $125(1): 39-47.1990$. 
WOLTZ, S.S. Nonparasitic plant pathogens. Ann. Rev. Phytopathology, Palo Alto, 16:403-430. 1978 .

YUEN, G.Y. \& SCHROTH, M.N. Interactions of Pseudomonas fleyorescens strain E6 with ornamental plants and its effect on the composition of root-colonizing microflora. Phytopathology, St. Paul, 76(2): 176-180. 1986 .

ZAADY, E.; PEREVOLOTSKY, A. \& OKON, Y. Promotion of plant growth by inoculum with aggregated and single cell suspensions of Azospirillum brasilense Cd. Soil Biol. Biochem., Oxford, 25(7):819-823. 1993 .

ZIEGLE, J. \& CORRELL, M.D. Inhibition of Fusarium oxysporum f. sp. apii in vitro and in vivo with fusarimycin - producing Pseudomonas fluorescens strain NP77A. Phytopathology, St. Paul, 78(12): 1522. 1988. (abstract). 